\title{
Seaweed Components as Potential Modulators of the Gut Microbiota
}

\author{
Emer Shannon ${ }^{1,2, *} \mathbb{0}$, Michael Conlon ${ }^{2}$ and Maria Hayes ${ }^{1}$ \\ 1 Food Biosciences, Teagasc Food Research Centre, Ashtown, D15 KN3K Dublin, Ireland; \\ Maria.Hayes@teagasc.ie \\ 2 CSIRO Health and Biosecurity, Kintore Avenue, Adelaide, SA 5000, Australia; Michael.Conlon@csiro.au \\ * Correspondence: Emer.Shannon@teagasc.ie; Tel.: +353-1-805-9980
}

Citation: Shannon, E.; Conlon, M.; Hayes, M. Seaweed Components as Potential Modulators of the Gut Microbiota. Mar. Drugs 2021, 19, 358. https://doi.org/10.3390/ md19070358

Academic Editor: Diana Cláudia Pinto

Received: 10 May 2021

Accepted: 20 June 2021

Published: 23 June 2021

Publisher's Note: MDPI stays neutral with regard to jurisdictional claims in published maps and institutional affiliations.

Copyright: (c) 2021 by the authors. Licensee MDPI, Basel, Switzerland. This article is an open access article distributed under the terms and conditions of the Creative Commons Attribution (CC BY) license (https:// creativecommons.org/licenses/by/ $4.0 /)$.

\begin{abstract}
Macroalgae, or seaweeds, are a rich source of components which may exert beneficial effects on the mammalian gut microbiota through the enhancement of bacterial diversity and abundance. An imbalance of gut bacteria has been linked to the development of disorders such as inflammatory bowel disease, immunodeficiency, hypertension, type-2-diabetes, obesity, and cancer. This review outlines current knowledge from in vitro and in vivo studies concerning the potential therapeutic application of seaweed-derived polysaccharides, polyphenols and peptides to modulate the gut microbiota through diet. Polysaccharides such as fucoidan, laminarin, alginate, ulvan and porphyran are unique to seaweeds. Several studies have shown their potential to act as prebiotics and to positively modulate the gut microbiota. Prebiotics enhance bacterial populations and often their production of short chain fatty acids, which are the energy source for gastrointestinal epithelial cells, provide protection against pathogens, influence immunomodulation, and induce apoptosis of colon cancer cells. The oral bioaccessibility and bioavailability of seaweed components is also discussed, including the advantages and limitations of static and dynamic in vitro gastrointestinal models versus ex vivo and in vivo methods. Seaweed bioactives show potential for use in prevention and, in some instances, treatment of human disease. However, it is also necessary to confirm these potential, therapeutic effects in large-scale clinical trials. Where possible, we have cited information concerning these trials.
\end{abstract}

Keywords: seaweed; prebiotics; gut microbiota; polysaccharides; polyphenols; peptides; colonic fermentation; short chain fatty acids; bioaccessibility; simulated gastrointestinal and fermentation digestion models

\section{Introduction}

Seaweed-derived components with potential to impact positively on diseases of the body including hypertension [1], cancer [2], type-2-diabetes [3], obesity [4], oxidation [5], inflammation [6] and other disorders have been evaluated in a number of studies to date [7-15]. The pathogenesis of these disorders has been linked to the health of the gut microbiota [16]. The microorganisms that inhabit the human gastrointestinal tract-bacteria, archaea, fungi, protozoa, and viruses-are collectively termed the gut microbiota [17]. The gut microbiota is established during infancy [18]. There is a broad variance amongst individuals in microbiota composition because it is shaped by infant transitions such as the gestational period, delivery method, weaning age, breast-feeding duration, or use of formula milk [19]. The microbiota remains relatively stable throughout adulthood but is affected by factors such as enterotype, antibiotic use, diet, lifestyle, genetic traits, and body mass index [20]. Three enterotypes have been described in the human gut microbiome based on variations in levels of the bacterial genera Bacteroides, Prevotella, and Ruminococcus [21]. The gut microbiota is regarded as an endocrine organ that co-develops with the host throughout its life. It exerts an effect on immunity, metabolism, neuroendocrine responses, and synthesises vitamins, amino acids, and enzymes [22,23]. 
The gut microbiota also aids in the absorption of dietary minerals and produces important short-chain fatty acids (SCFA) such as butyrate, propionate, and acetate. These SCFA are the energy source for gastrointestinal epithelial cells, provide protection against pathogens, influence intestinal mucosal immunity and barrier integrity, and induce apoptosis of colon cancer cells [24,25]. SCFA also regulate liver mitochondrial function, insulin secretion, and induce the production of gut hormones $\gamma$-aminobutyric acid and serotonin by interacting with their receptors on enteroendocrine cells [26,27]. An increase in the gut bacterial population enhances the beneficial effects of the microbiota and increases SCFA production [20]. An imbalance or decreased diversity of beneficial versus harmful bacterial species in the gut microbiota is termed dysbiosis and is linked to several diseases [28-32]. Therefore, maintaining the health of the microbiota through diet or supplementary means is thought beneficial to overall health [30]. Seaweed components may exert a beneficial effect on gut health by acting as prebiotics $[33,34]$. The potential bioactivity of seaweed components has been demonstrated previously in in vitro studies $[35,36]$, however the impact of gastrointestinal enzymatic digestion and colonic bacterial fermentation in vivo must also be considered, since it may have an effect on the bioavailability of prebiotic and other actives [37-39]. As a pharmacological concept, bioavailability is a measure of drug absorption defined as the percentage of the drug that reaches blood circulation, measured by a dose-response curve [40]. However, the evaluation of bioavailability in food-derived extracts differs, since characteristic dose-response curves are not exhibited [41]. In addition, the bioaccessibility of food-derived active compounds must be taken into account, i.e., the accessible portion of the active compound released from the food or extract matrix during digestion [42,43]. Although pharmacokinetic studies are required for the development of prebiotics destined for human and animal use, such studies are not within the scope of this review. The pharmacokinetics of seaweed-derived prebiotics in terms of absorption, distribution, metabolism, and elimination has previously been documented in animal studies after oral administration [44-48] and topical application [49], and recently reviewed by Corino et al. [50] and Shikov et al. [51].

This review outlines current knowledge on the potential beneficial effect of seaweed polysaccharides, polyphenols, and peptides on the gut microbiota and the impact of gastrointestinal digestion and colonic fermentation on their bioaccessibility. The advantages and limitations of static and dynamic gastrointestinal models, and in vitro, ex vivo, and in vivo bioaccessibility and bioavailability assessment methods concerning seaweed bioactives and their prebiotic and potential beneficial health effects are discussed.

\section{Discussion}

Seaweed components that have the potential to exert beneficial effects on the gut by modulating the abundance and diversity of bacterial populations in the gut microbiota include polysaccharides, polyphenols, and peptides. Their structure, function, and studies regarding their potential impact on the gut are considered in this review. Despite the positive results reported from cited studies concerning in vitro and animal work, more research is required in human dietary intervention studies, with health-related end points, to determine prebiotic potential.

\subsection{Polysaccharides}

Polysaccharides, or carbohydrates, are repeating units of monosaccharides linked by glycosidic bonds found in all plants, fungi, and algae. They are considered primary metabolites with structural and energy storage functions [52]. The majority of seaweed polysaccharides are composed of water-soluble and -insoluble fibre [53,54]. The total fibre content of seaweed varies between species and has been reported to range from $35-62 \%$ in brown, to $10-57 \%$ in red and $29-67 \%$ in green (DW) [55-59]. The principal fibres in brown seaweeds are fucoidan, laminarin, and alginate; porphyran, carrageenan, hypnean and floridean starch in red; and ulvan, sulphated-rhamnans, -arabinogalactans and -mannans in green $[60,61]$. Humans do not produce the endogenous enzymes in the 
upper gastrointestinal tract required to degrade dietary fibre to monosaccharides. However, fibre is an excellent food substrate, or prebiotic, for human gut bacteria [62,63]. Prebiotics are food components that are indigestible in the small intestine but can be metabolised by microorganisms in the large intestine, modulating their composition and/or activity, thus conferring a beneficial physiological effect on the host [64]. Many species of gut bacteria produce endogenous carbohydrate-degrading enzymes, such as $\beta$-glucanase and $\beta$-glucosidase, capable of hydrolysing the glycosidic linkages of polysaccharides [65-68]. Several polysaccharides within seaweed that are indigestible in the upper gastrointestinal tract are thought to exert bioactive effects including glycaemic control [69] and the promotion of gut microbial- and immune-modulation by acting as prebiotics in in vitro and in vivo studies $[70,71]$. The bioactivity of polysaccharide fractions is influenced by a number of factors such as chemical structure, molecular weight (MW), solubility, extraction method, seaweed genus and seasonal variation [72,73]. The principal polysaccharides of brown, red, and green seaweeds are detailed below.

\subsubsection{Fucoidans}

Three polysaccharides-fucoidans, laminarin and alginate-occur within brown seaweeds, each of which have differing structures and functions [74]. Fucoidans comprise $5-20 \%$ (DW) of the entire seaweed thallus $[75,76]$. They are water-soluble sulphatedpolysaccharides composed of repeating fucose and sulphate groups, and may also contain galactose, mannose, xylose, rhamnose, arabinose, glucose, acetyl groups, or glucuronic acid [77]. The molecular weight of fucoidans varies from 7 to $2300 \mathrm{kDa}$ [11]. Fucoidans provide structure for the outer cell wall and a hydrophilic coating to prevent desiccation of the seaweed during low tide. They also play a role in adapting to osmotic stress caused by changes in salinity as their sulphate groups can bind to cations such as sodium, potassium, magnesium, and calcium $[78,79]$. Fucoidans have previously been shown in in vitro studies to have potential for use as anticancer [80], antiviral [81], antioxidant [77], and anti-inflammatory [82] agents; and in vivo as anticoagulants (human trial) [83], anticancer (human trial) [84], antitumour (mouse model) [85], antihyperglycaemic, and antihyperlipidaemic agents (mouse model) [86]. However, the oral bioavailability of fucoidan can be low due its highly polar nature and limited ability to pass through intestinal epithelial cells [68]. In recent years, the prebiotic status of fucoidan has been recognised in vitro $[82,87]$ and in human [88] and animal [89-92] gastrointestinal studies.

\subsubsection{Laminarin}

The energy storage polysaccharide of brown seaweeds is laminarin, composed of $\beta(1-3)$-linked glucose units with $\beta(1-6)$-branches [93]. It occurs within the chloroplasts in micro-compartments called pyrenoids [94]. Laminarin is water-soluble, though increased branching of the molecule requires colder temperatures for solubility. It comprises $3-35 \%$ of brown seaweed dry mass and is most prevalent in Laminaria species [95]. It is a small polysaccharide with a molecular weight of approximately $5 \mathrm{kDa}$ [96]. Laminarin has shown efficacy in in vitro studies carried out previously and has potential for use as an anticancer [97], antimetastatic [98], antioxidant [99] and immunostimulatory [100] agent $[97,99,100]$; and in vivo as an immunomodulatory agent [101] and prebiotic to modulate dysbiosis (animal models) [102-105].

\subsubsection{Alginate}

Alginate comprises up to $45 \%$ of brown seaweed dry mass [106], occurring in the cell walls as salts of alginic acid bound to sodium, calcium or magnesium ions [107]. It is a water-soluble linear polysaccharide composed of (1-4)-linked $\beta$-D-mannuronate and $\alpha$-L-guluronate residues [108]. Molecular weight ranges from 20 to $350 \mathrm{kDa}[109,110]$. It is the most abundant polysaccharide in brown seaweed and imparts flexibility to the thallus to withstand the force of the ocean. Alginate is a phycocolloid that can bind up to 20 times its own mass with water, making it very useful for food and industrial applications [111]. 
The prebiotic effect of alginate on gut microbiota was demonstrated previously in vitro by Bai et al. [112] and Li et al. [113]; and in a human study by Mizuno et al. [114]. Bai et al. fermented seaweed-derived alginates in vitro and observed that the alginates were degraded by human-derived gut bacteria, producing a significant $(p<0.05)$ increase in SCFA compared to a starch control, and suggested that further investigations of the prebiotic effects of alginate are warranted. Li et al. also fermented seaweed-derived alginates with human faecal bacteria in vitro and found a significant $(p<0.05)$ increase in total SCFA in the alginate sample $(78.6 \pm 5.9 \mathrm{mM})$ compared to the control $(62.5 \pm 5.1 \mathrm{mM})$. The bacterial Richness index in the alginate ferment $(15.83 \pm 2.3)$ was also significantly greater $(p<0.05)$ than that of the control $(12.67 \pm 2.88)$. The authors propounded that alginate may be capable of sustaining the growth of human gut bacteria, and recommended further study to evaluate the potential impact that alginate food additives may exert on host health. The in vivo study by Mizuno et al. was an interventional study of 11 elderly patients who required enteral feeding. After 4 weeks of receiving the alginate formula (equivalent to $14.52 \mathrm{~g}$ fibre/day) there was a significant increase $(p=0.039)$ in Clostridium cluster XI bacteria compared with the baseline. However, there was no increase in Bifidobacterium, Lactobacillales, or Bacteroides. The patients' stool form improved $(p=0.044)$ (Bristol Stool Scale), as did mean blood concentrations of total SCFA $(p=0.042)$, acetic acid $(p=0.042)$, propionic acid $(p=0.027)$, serum albumin $(p=0.039)$, total cholesterol $(p=0.002)$, and cholinesterase $(p=0.034)$. The alginate did not induce any significant changes in stool frequency, body weight, or arm circumference. The authors suggested that the alginatecontaining liquid formula may potentially exert a beneficial prebiotic effect on intestinal function through increased production of SCFA. However, the limitations of the study were noted due to the small sample size and single-center study design. In order to validate the findings, the authors recommend a larger, multicenter study.

Alginate may also be useful in the prevention of metabolic syndrome syndrome [115]. It can increase the viscosity of gastric contents, reducing postprandial glucose absorption and insulin response [116], and may thereby impact on hyperlipidaemia and hypertension $[1,117]$.

\subsubsection{Carrageenans}

Within red seaweeds, carrageenans and porphyran are the prevalent polysaccharides. The family of linear, sulphated polysaccharides, carrageenans, occur as a structural component of the extracellular matrix [118]. Of the 15 different carrageenan forms, iota ( $\iota$, kappa $(\kappa)$ and lambda $(\lambda)$ are the most widely used as phycocolloids in the food industry [119] and as a vegan alternative to beef gelatin in pharmaceutical capsules [120]. $K$ and $\iota$-carrageenan are composed of alternating D-galactose and 3,6-anhydro-galactose units with varying numbers of sulphate groups, while $\lambda$-carrageenan lacks 3,6-anhydro-galactose and has alternating $\alpha-1,3$ and $\beta-1,4$ inter-galactose bonds [121]. Average molecular weight ranges from 453 to $652 \mathrm{kDa}$ [122]. All forms of carrageenan are soluble in water above their gelmelting temperatures $\left(40-70^{\circ} \mathrm{C}\right)$. In cold water, only $\lambda$-carrageenan and the sodium salts of $\kappa$ and $\mathrm{l}$-carrageenan are soluble [93]. $\mathrm{l}$-carrageenan was shown to reverse the symptoms of metabolic syndrome in a rat model by significantly decreasing systolic blood pressure, body mass (BM), abdominal and liver fat, and total cholesterol, while also beneficially modulating the gut microbiota [123]. As potential antitumour agents, $\mathrm{k} / \mathrm{\iota}$ hybrid carrageenans have shown activity in vitro against colorectal cancer stem cell-enriched tumourspheres [2]. However, simulated gastrointestinal studies have found that $\mathrm{k}$-carrageenan can be both beneficial and harmful by increasing or decreasing markers of inflammation and the growth of beneficial gut bacteria and SCFA. This is dependent on the degree of polymerisation of the carrageenan [124].

\subsubsection{Porphyran}

Porphyran is a sulphated polysaccharide that occurs in red seaweed, within the genus Porphyra, and comprises approximately $11-21 \%$ of the seaweed dry mass [125]. It is 
composed of repeating units of galactose and 3,6-anhydrogalactose, with alternating units of galactose-6-sulphate and 6-O-methyl-galactose [126]. Average molecular weight ranges from 14 to $201 \mathrm{kDa}[127,128]$. Porphyran is soluble in hot water and has similar structural functions to carrageenan, though its higher viscosity limits its pharmaceutical applications $[128,129]$. Porphyran has shown potential antioxidant and anti-inflammatory effects in cell studies using RAW264.7 cell line [125] and was found to promote cell migration and proliferation in intestinal epithelial cells [127]. It also has antitumor activity against HeLa cells [130], HT-29 colon cancer cells and AGS gastric cancer cells [131]. As a prebiotic, porphyran was previously found to increase beneficial gut bacteria and SCFA production in vitro in simulated digestion studies $[126,132,133]$ and in animal studies as whole red seaweed [134-136].

\subsubsection{Ulvans}

Green seaweeds are dominated by the ulvans, which account for $38-54 \%$ of the thallus dry mass [137]. Ulvans are water-soluble, gelling polysaccharides composed of repeating units of sulphated L-rhamnose, D-xylose, D-glucuronic acid and its epimer Liduronic acid [138]. Molecular weights range widely from 1 to $2000 \mathrm{kDa}$ depending upon the degree of sulphation [139]. Ulvans have demonstrated potential anticoagulant [140], antibacterial [141], antiviral [142], and immunoregulatory (porcine intestinal epithelial cells) [143] activities in vitro. They have also shown potential for the use as prebiotics in animal studies [144] and in vitro [132,145,146].

\subsection{Gastrointestinal Digestion Studies with Seaweed Polysaccharides}

A number of recent studies have used simulated in vitro gastrointestinal digestion or in vivo clinical trials to investigate the effect of polysaccharides on beneficial bacterial populations and their metabolites. Table 1 summarises the polysaccharide fraction used in each study and its impact on gut bacteria. Further characterisation and in vivo animal and human dietary intervention studies are required to confirm any potential therapeutic benefits.

Table 1. The impact of polysaccharides on gut bacteria.

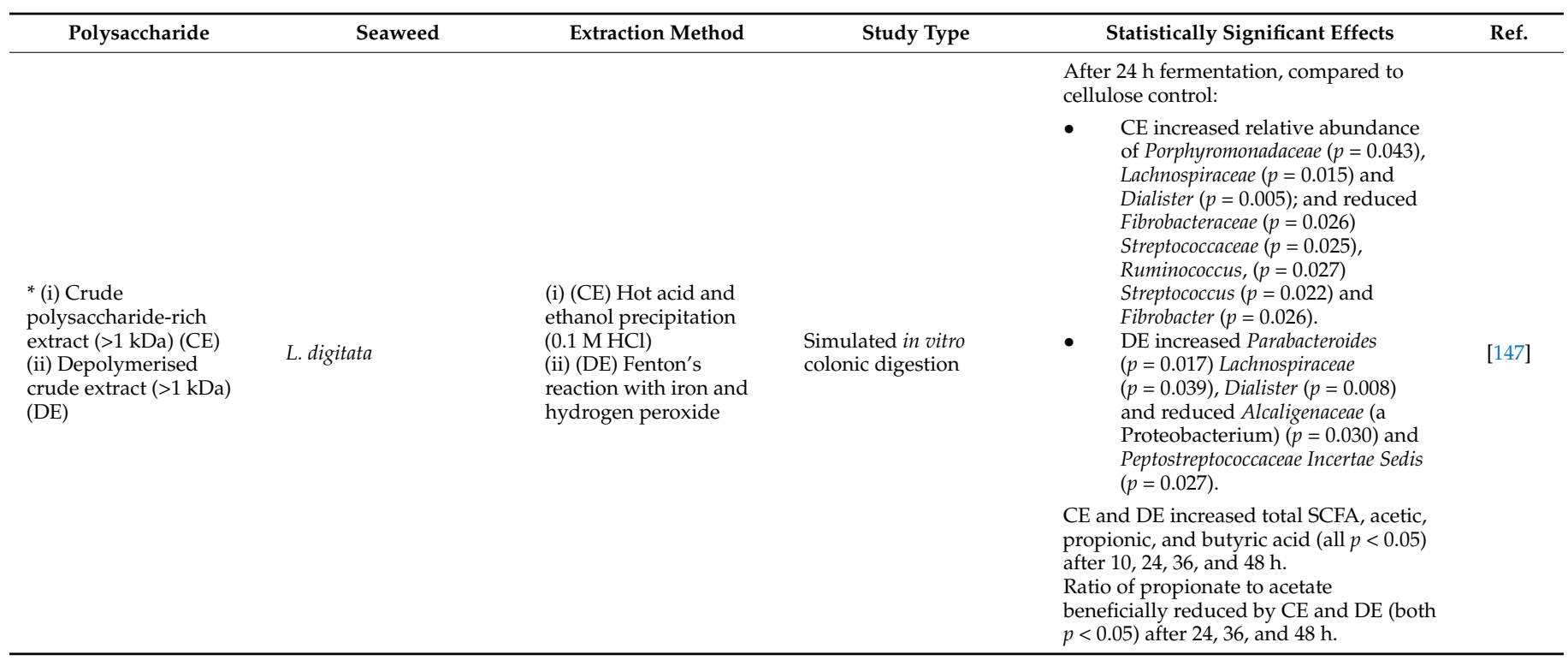


Table 1. Cont.

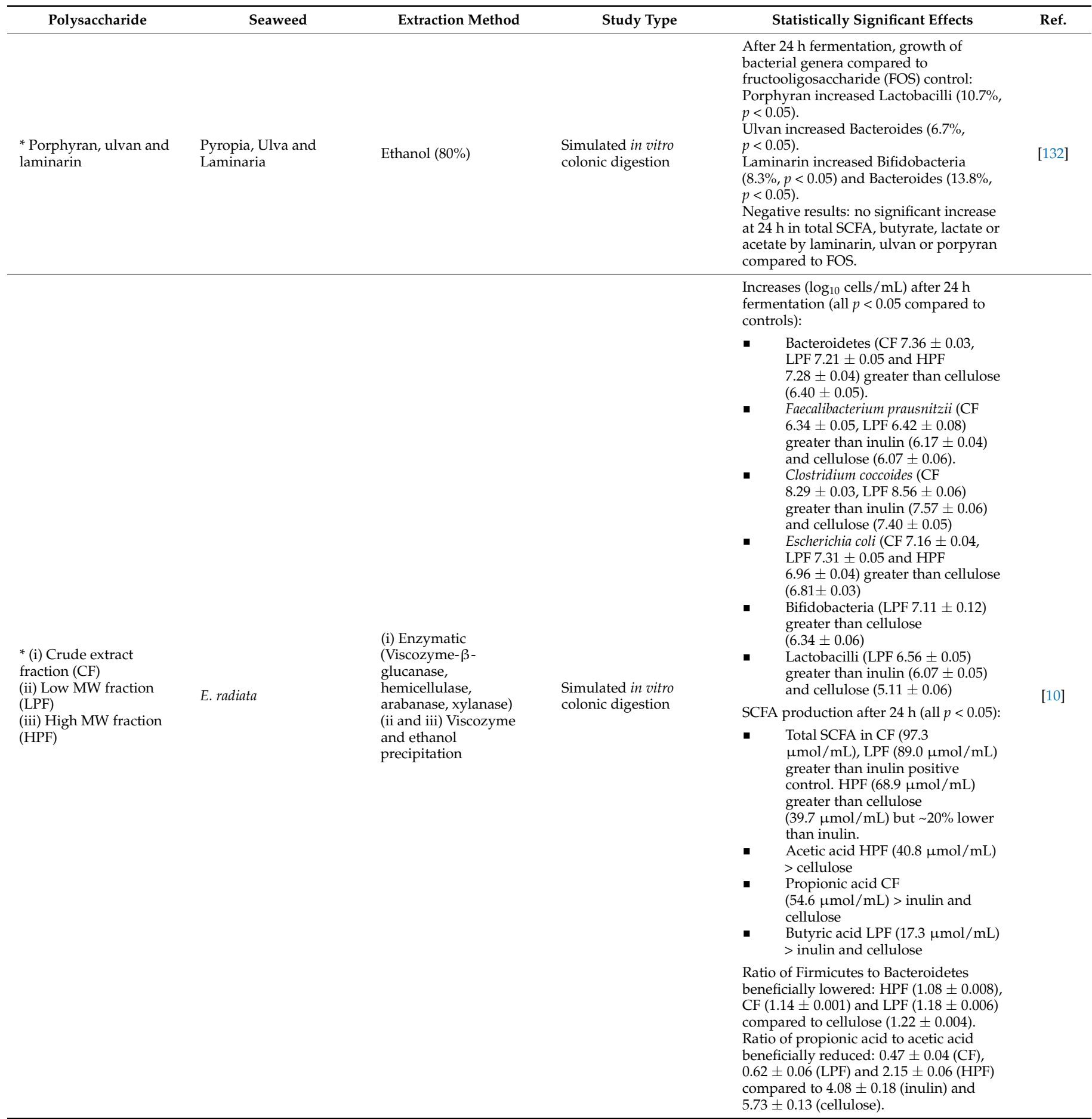


Table 1. Cont.

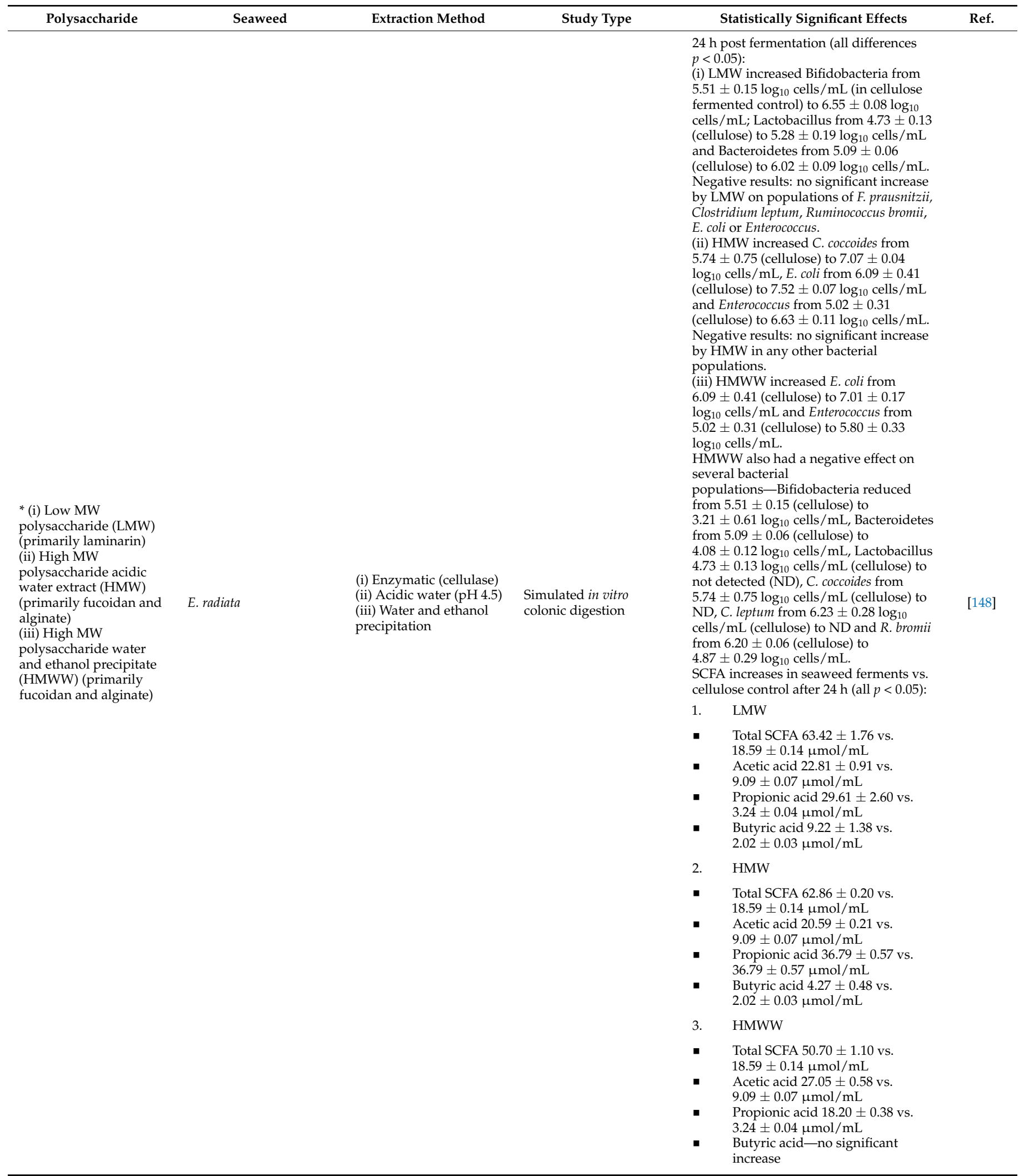


Table 1. Cont

\begin{tabular}{|c|c|c|c|c|c|}
\hline Polysaccharide & Seaweed & Extraction Method & Study Type & Statistically Significant Effects & Ref. \\
\hline $\begin{array}{l}\text { ** (i) Polysaccharide } \\
\text { fraction (PF) (primarily } \\
\text { fucoidan and alginate) } \\
\text { (ii) Whole seaweed } \\
\text { (WS) }\end{array}$ & E. radiata & $\begin{array}{l}\text { (i) Enzymatic } \\
\text { (Viscozyme) } \\
\text { (ii) Whole dried } E . \\
\text { radiata }\end{array}$ & $\begin{array}{l}\text { In vivo trial with healthy } \\
\text { Sprague-Dawley rats } \\
\text { (7 d, 5\% PF or } 5 \% \text { WS } \\
\text { added to feed) }\end{array}$ & 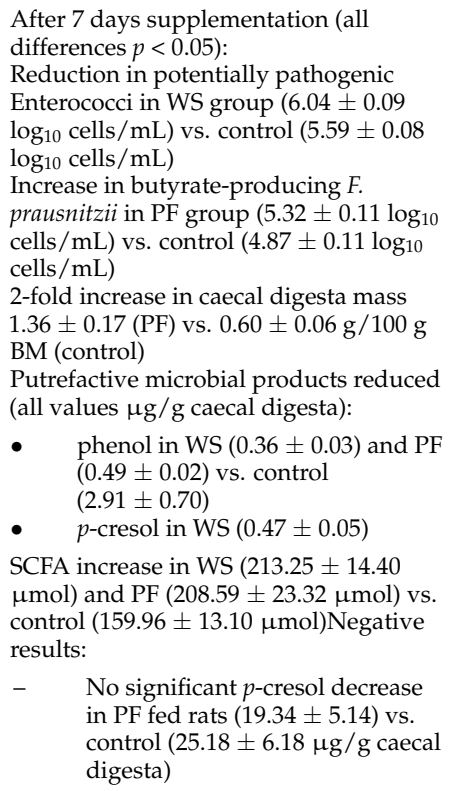 & [149] \\
\hline $\begin{array}{l}\text { * (i) conventional } \\
\text { chemical extraction } \\
\text { (CCE) (11.9\% fucoidan) } \\
\text { (ii) microwave-assisted } \\
\text { extraction (MAE) } \\
\text { (5.71\% fucoidan) } \\
\text { (iii) ultrasound-assisted } \\
\text { extraction (UAE) } \\
\text { (4.56\% fucoidan) } \\
\text { (iv) enzyme-assisted } \\
\text { extraction (EAE) } \\
\text { (3.89\% fucoidan) }\end{array}$ & A. nodosum & $\begin{array}{l}\text { (i, ii, and iii) Ethanol } \\
\text { followed by acidic } \\
\text { water }(0.01 \mathrm{M} \mathrm{HCl}) \\
\text { (iv) Cellulase, acetate } \\
\text { buffer ( } \mathrm{pH} 4.5)\end{array}$ & $\begin{array}{l}\text { L. casei and } L \text {. delbrueckii } \\
\text { ssp. bulgaricus broth } \\
\text { cultures, } 3.75 \%(v / v) \text {. } \\
\text { A. nodosum extracts } \\
\text { added at } 0.1 \%, 0.3 \% \text { and } \\
0.5 \%(w / v)\end{array}$ & $\begin{array}{l}\text { All differences } p<0.05 \text { compared to } \\
\text { non-supplemented control medium: } \\
\text { Increase in L. delbrueckii ssp. bulgaricus } \\
\text { by CCE, MAE, UAE and EAE at } 0.1 \% \text {, } \\
0.3 \% \text { and } 0.5 \% \text {. } \\
\text { Increase }(24.5 \%) \text { in L. casei only by MAE } \\
\text { at } 0.5 \% \text { inclusion. } \\
\text { Negative results: } \\
\text { - No significant increase in L. casei } \\
\text { by CCE, UAE or EAE vs. } \\
\text { non-supplemented media. }\end{array}$ & [87] \\
\hline $\begin{array}{l}\text { * Crude sulphated } \\
\text { polysaccharide } \\
\text { ( } 716 \mathrm{kDa})(90 \% \\
\text { galactose, } 9.07 \% \\
\text { sulphate) }\end{array}$ & C. pilulifera & $\begin{array}{l}\text { Acidic extraction }(0.0 .1 \\
\mathrm{M} \mathrm{HCl}) \text { and ethanol } \\
\text { precipitation }\end{array}$ & $\begin{array}{l}\text { Simulated in vitro saliva, } \\
\text { gastric, small intestinal } \\
\text { and colonic digestion }\end{array}$ & $\begin{array}{l}\text { After } 24 \mathrm{~h} \text {, all differences } p<0.05 \\
\text { compared to inulin control: } \\
\text { Increase in Bacteroides, Parabacteroides, } \\
\text { Megamonas and Veillonella. } \\
\text { Increase in total SCFA } \\
(22.17 \pm 0.82 \mathrm{mmol} / \mathrm{L}) \text { vs. control } \\
(16.17 \mathrm{mmol} / \mathrm{L} \pm 0.39) . \\
\text { Negative results: } \\
\text { - No significant increase in } \\
\quad \text { butyrate, lactate, iso-butyrate, } \\
\text { valerate or iso-valerate in } \\
\text { seaweed polysaccharide } \\
\text { supplemented ferments. }\end{array}$ & [150] \\
\hline $\begin{array}{l}* \text { (i) Polysaccharides } \\
(\mathrm{SJP})(138 \mathrm{kDa})(\mathrm{Fu}- \\
\text { cose:galactose:glucuronic } \\
\text { acid:mannose, molar } \\
\text { ratio of } 4.1: 3.6: 1.2: 1.0) \\
\text { (ii) Oligosaccharides } \\
\text { (SJO) }\end{array}$ & S. japonica & $\begin{array}{l}\text { (i) Methanol, } \\
\text { dichloromethane, water } \\
\text { and ethanol } \\
\text { (ii) Methanol, } \\
\text { dichloromethane, water } \\
\text { and ethanol, followed } \\
\text { by } 0.6 \mathrm{M} \mathrm{HCl}\end{array}$ & $\begin{array}{l}\text { Simulated in vitro } \\
\text { colonic digestion }\end{array}$ & $\begin{array}{l}\text { After } 24 \mathrm{~h} \text {, all differences } p<0.05 \\
\text { compared to FOS control } \\
\text { - } \quad \text { Increase in beneficial } \\
\text { Bacteroidetes and decrease in } \\
\text { Proteobacteria (SJP and SJO). } \\
\text { - } \quad \text { Increased ratio of Bacteroidetes to } \\
\text { Firmicutes (SJP and SJO). }\end{array}$ & [91] \\
\hline
\end{tabular}


Table 1. Cont.

\begin{tabular}{|c|c|c|c|c|c|}
\hline Polysaccharide & Seaweed & Extraction Method & Study Type & Statistically Significant Effects & Ref. \\
\hline $\begin{array}{l}{ }^{* *} \text { Crude sulphated } \\
\text { polysaccharide (SP) } \\
(28.807 \mathrm{kDa})(\text { Galactose } \\
(59.7 \%), \text { galacturonic } \\
\text { acid }(19.8 \%) \text {, xylose } \\
(7.1 \%) \text { and sulphate } \\
(8.8 \%))\end{array}$ & G. pacificum & $\begin{array}{l}\text { Ultrasound-assisted } \\
\text { water extraction } \\
\text { followed by ethanol, } \\
\text { acetone and petroleum } \\
\text { precipitation }\end{array}$ & $\begin{array}{l}\text { In vivo trial with } \\
\text { lincomycin } \\
\text { hydrochloride induced } \\
\text { diarrhoeal mice ( } 9 \text { days, } \\
75 \mathrm{mg} \mathrm{SP} / \mathrm{kg} \mathrm{BM})\end{array}$ & $\begin{array}{l}\text { After } 9 \mathrm{~d} \text {, seaweed polysaccharide group } \\
\text { vs. non-supplemented normal recovery } \\
\text { group (all differences } p<0.05 \text { ): } \\
\text { Increase in beneficial Bacteroides, } \\
\text { Oscillospira and Bifidobacterium. } \\
\text { Decrease in Parabacteroides, Sutterella } \\
\text { and AF12. } \\
\text { Reduction in inflammatory cytokines, } \\
\text { TNF- } \alpha \text {, IL-1 } \beta \text { and IL-2. } \\
\text { Improved (lower) diarrhoea status } \\
\text { scores, water intake, and less weight loss. } \\
\text { Increase in total SCFA, acetate and } \\
\text { propionate. }\end{array}$ & [151] \\
\hline \multirow{4}{*}{$\begin{array}{l}* * \text { Fucoidan }(300 \mathrm{kDa}) \\
(60 \% \text { fucose }, 14.3 \% \\
\text { sulphate) }\end{array}$} & \multirow{4}{*}{ C. okamuranus } & & \multirow{4}{*}{$\begin{array}{l}\text { In vivo trial with Traf3 } \\
\text { ip2-mutant psoriasis } \\
\text { mice (fucoidan diet } \\
\text { group } n=14 \text {, normal } \\
\text { diet group } n=9 \text {, } \\
63 \text { days, } 1 \% \text { fucoidan } \\
\text { added to feed) }\end{array}$} & $\begin{array}{l}\text { Fucoidan group vs. cellulose control } \\
\text { group (all differences } p<0.05 \text { ). } \\
\text { After } 56 \text { days: }\end{array}$ & \multirow{4}{*}{ [89] } \\
\hline & & Method not specified & & $\begin{array}{l}\text { Increase (\% relative abundance) } \\
\text { in Bacteroidetes }(78.2 \pm 6.42 \text { vs. } \\
59.4 \pm 9.69 \%), \text { Proteobacteria } \\
(3.05 \pm 0.62 \text { vs. } 1.73 \pm 0.53 \%), \\
\text { and Paraprevotellaceae. } \\
\text { Decrease in Firmicutes } \\
(16.3 \pm 4.98 \text { vs. } 34.3 \pm 9.05 \%) \text { and } \\
\text { TM7 Saccharibacteria ( } 3.80 \pm 0.24 \\
\text { vs. } 1.23 \pm 0.11 \%) . \\
\text { After } 21 \text { days increase in mucin } \\
\text { - } \quad \text { production in ileum and faeces } \\
\text { After } 63 \text { days increase in IgA } \\
\text { production in cecum }+ \\
\text { Reduction in psoriasis area and } \\
\text { severity index (PASI) and } \\
\text { ethological scratch-test }\end{array}$ & \\
\hline & & & & Negative results: & \\
\hline & & & & $\begin{array}{l}\text { - Decreases in Deferribacteres and } \\
\text { Actinobacteria after } 56 \text { days were } \\
\text { not significant }\end{array}$ & \\
\hline
\end{tabular}

Compared with non-supplemented group, seaweed extract supplemented (SWE) sows had:

- Greater colostrum $\operatorname{IgA}(p<0.01)$ and $\operatorname{IgG}(p=0.062)$

- Decreased faecal Enterobacteriaceae populations at parturition $(p<0.05)$

- Reduced faecal Enterobacteriaceae on expected farrowing date (7.26 vs. $8.60 \log _{10} \mathrm{CFU} / \mathrm{g}$, pooled SEM $0.463, p<0.05$ )

LPS challenge increased

In vivo trial (10 pregnant sows/treatment) $(10 \mathrm{~g} /$ days seaweed extract from day 107 of

** Laminarin and fucoidan $(10 \%$ laminarin $8 \%$ fucoidan and $82 \%$ ash)
Method not specified gestation until weaning (day 26)) and ex vivo lipopolysaccharide (LPS) immunological challenge pro-inflammatory cytokines IL- $1 \alpha$ and IL-6 $(p<0.01)$ in ileal tissue and tumor necrosis factor (TNF)- $\alpha$ in colonic $(p<0.01)$ tissue

Piglets suckling SWE sows had:

- Greater TNF- $\alpha$ after ex vivo LPS challenge $(p<0.05)$

- Increased serum IgG $(p<0.05)$ on day 14

- $\quad$ Decreased colonic E. coli population $(p<0.01)$ at weaning Greater Lactobacilli: E.coli ratio $(p<0.05)$

Negative results:

- $\quad$ No increase in faecal volatile fatty concentrations in SWE sows SWE diet had no effect on TNF- $\alpha$ mRNA expression in unchallenged sow ileal tissue Piglet birth and weaning weight, and small intestinal morphology unaffected by SWE sow diet 


\subsection{Polyphenols}

Polyphenols are secondary metabolites that occur ubiquitously in terrestrial plants and algae. They are composed of repeating units of phenol-an aromatic phenyl group (a benzene ring, minus one hydrogen atom) bound to one or more hydroxyl groups [152]. Polyphenols are involved in numerous functions. They protect the seaweed thallus against biotic and abiotic stresses such as predation from herbivores, microbial infection, oxidation, and UV damage [153]. The total polyphenolic content of brown seaweed (dry mass) can be as high as $20 \%$, while green and red seaweeds contain 1-5\% [154-156]. The molecular weight of seaweed polyphenols ranges from approximately $26 \mathrm{Da}$ to $650 \mathrm{kDa}[157,158]$. Seaweed polyphenols have been found to increase high-density lipoprotein cholesterol [159], post-prandial cognitive function [160], and exert anti-hypertensive [161] anti-hyperglycaemic [162] and peak blood glucose reducing effects (females only) [163] in human studies. However, only $5-10 \%$ of polyphenols are absorbed in the upper gastrointestinal tract due to their structural complexity. Large polyphenol compounds that reach the large intestine can be converted by microbial activity into beneficial bioactive metabolites [164,165], while also inhibiting pathogenic species [166]. Gut microbial enzymes catabolise polyphenols via hydrolysis, dehydroxylation, decarboxylation, reduction, demethylation, and isomerisation [167]. Studies with germfree animals have shown that bioactive phenolic metabolitesnormally found after oral administration of polyphenols-are absent in their gut [168]. This shows the importance of the gut microbiota in polyphenol metabolism.

In terrestrial plants, the predominant polyphenols are flavonoids, stilbenes, lignans, and phenolic acids [169]. Seaweeds also produce flavonoids, coumarins, phenolic terpenoids, phenolic acids, luteolin, regiolone, and neoeriocitrin as well other polyphenols that are unique to algae [170-172]. These include bromophenols and phlorotannins [173].

\subsubsection{Bromophenols}

Bromophenols are molecules composed of one to five phenol groups, bound to one or more bromine [174]. Bromophenols are produced by seaweed as part of their chemical defence system to protect them from herbivores [175], oxidation, bacteria, and fungi [176,177]. Tri-bromophenols are the most common isomers found in seaweed, followed by di- and mono- bromophenols [178]. Bromophenols occur most abundantly in red and green seaweeds, and to a lesser extent in brown genera. A study of 49 red, green, and brown seaweeds by Whitfield et al. [179] reported bromophenol contents ranging from 8 to $2590 \mathrm{ng} / \mathrm{g}$ in red, 0.9 to $2393 \mathrm{ng} / \mathrm{g}$ in green, and 2 to $454 \mathrm{ng} / \mathrm{g}$ in brown. Seaweed-derived bromophenols have antioxidant [180], anti-inflammatory [181], antibacterial [182], anti-cancer [183], antithrombotic [184], and antidiabetic [185] activity.

\subsubsection{Phlorotannins}

Phlorotannins, found only in brown seaweeds, are composed of repeating units of phloroglucinol—a phenyl ring bound to three hydroxyl groups. Due to their ability to precipitate proteins, they are considered tannins [186]. Phlorotannins have structural functions within the seaweed cell wall [187], and protect against oxidation [188] and predation by herbivores [189]. Phlorotannins are sub-classified into four main groups depending upon the type of chemical bonds that link their phloroglucinol units [190]. Fuhalols and phlorethols have ether bonds; fucols have phenyl bonds; fucophlorethols have phenyl and ether bonds; while eckols have dibenzodioxin bonds [191]. The molecular weight of phlorotannins ranges broadly depending upon the number of phloroglucinol units they contain [192]. Molecular weights have been reported from 1.2 to $6 \mathrm{kDa}$ [193], 30 to $100 \mathrm{kDa}$ [194], and as high as $300 \mathrm{kDa}$ [195]. Phlorotannin content differs broadly amongst species, and is influenced by seasonal variations and geographic location [196,197]. Content is generally expressed as gallic acid or phloroglucinol equivalents, or as a percentage of seaweed dry mass. A study of eight brown seaweeds over 14 months from the same location in France by Connan et al. [196] reported significant inter- and intra-species seasonal differences in phlorotannin content, with the highest values occurring in summer. 
Values ranged from $0.13 \%$ phlorotannin content (DW of total seaweed) in L. digitata, to $5.80 \%$ in A. nodosum and F. vesiculosus. Phlorotannins have been studied for their potential health effects. Reported bioactivities include antioxidant [198], antidiabetic [199], anticancer [200], antihypertensive [201], anti-inflammatory [202], antiviral [203], neuroprotective [204], antimicrobial [205], and prebiotic activities [10,206,207].

\subsection{In Vitro and In Vivo Gastrointestinal Digestion Studies with Seaweed Polyphenols}

The effect of polyphenols, particularly phlorotannins, on the gut, metabolic syndrome, and DNA damage has been reported in some in vitro and in vivo studies which are discussed below.

\subsubsection{Prebiotic Function and Attenuation of Metabolic Syndrome by Phlorotannins}

Charoensiddhi et al. [10] evaluated the prebiotic potential of phlorotannin enriched (PE) ethanolic extracts in vitro from E. radiata harvested in Australia. After $24 \mathrm{~h}$ fermentation, the phlorotannin extracts induced significant increases (all $p<0.05$ ) in some populations of beneficial bacteria, which were selected for the study due to their relevance to gut health [10]. These were: Bacteroidetes $\left(6.52 \pm 0.04 \log _{10}\right.$ cells $\left./ \mathrm{mL}\right)$ compared to the cellulose control $\left(6.40 \pm 0.05 \log _{10}\right.$ cells $\left./ \mathrm{mL}\right) ;$ F. prausnitzii $\left(6.57 \pm 0.05 \log _{10}\right.$ cells $\left./ \mathrm{mL}\right)$ compared to inulin and cellulose controls (6.17 \pm 0.04 and $6.07 \pm 0.06 \log _{10}$ cells $/ \mathrm{mL}$, respectively); $C$. coccoides $\left(7.97 \pm 0.05 \log _{10}\right.$ cells $\left./ \mathrm{mL}\right)$ compared to inulin and cellulose controls $(7.57 \pm 0.06$ and $7.40 \pm 0.05 \log _{10}$ cells $/ \mathrm{mL}$, respectively); and E. coli $\left(8.09 \pm 0.02 \log _{10}\right.$ cells $\left./ \mathrm{mL}\right)$ compared to inulin and cellulose controls $\left(6.81 \pm 0.03\right.$ and $6.94 \pm 0.03 \log _{10}$ cells $/ \mathrm{mL}$, respectively). However, the production of SCFA was not enhanced by fermentation with the phlorotannin extract.

Lin et al. [170] reported the effect of a polyphenolic extract from the green seaweed, Enteromorpha prolifera, harvested in China, on the gut microbiome and glucose metabolism of diabetic mice. Polyphenols were extracted from E. prolifera using ultrasound-assisted ethanol and ultrafiltration to a MW of $3 \mathrm{kDa}$. The extract was characterised by UPLC-MS and found to contain four polyphenols-luteolin-6-c-glucoside, regiolone, neoeriocitrin, and estr-5(10)-ene-3,17-diol. Diabetes was induced in ICR mice (20/group) using STZ. Ten of the diabetic mice received a high-sucrose/high-fat diet with no polyphenol supplement (model group); while 10 received a high-sucrose/high-fat diet with E. prolifera polyphenol extract (300 mg/kg BM/d) (diabetic group). A control group of non-diabetic mice received standard chow (normal group).

After 28 days, there was an increase $(p<0.05)$ in the abundance of beneficial Alistipes intestinal bacteria in the polyphenol-fed diabetic group compared to the model group. After 14 days, there was a significant reduction $(p<0.05)$ in the mean BM of the E. proliferafed diabetic group compared to the model group. After 28 days, fasting blood glucose levels of the diabetic group were lower $(p<0.05)$, and glucose tolerance was increased $(p<0.05)$ compared to the model group.

Histopathological analysis of the liver revealed that the polyphenol-fed diabetic group had less cell damage and inflammation of the hepatic cord than the model group. The mRNA expression of two proteins associated with glucose metabolism was also measured in liver tissue - phosphatidylinositol 3-kinase (PI3K) and c-Jun N-terminal kinase (JNK). The PI3K pathway regulates insulin signal transduction and glucose homeostasis [208], while over-activity of the JNK pathway is linked to insulin resistance and type-2diabetes [209]. After 28 days, mRNA expression of PI3K was increased in the diabetic group $(p<0.01)$ compared to the model group, and was even significantly higher than the normal group $(p<0.05)$. JNK1 expression in the diabetic group was successfully downregulated by polyphenol supplementation and was lower $(p<0.05)$ than the model group.

Yuan et al. [210] investigated the ability of polyphenol extracts from the brown seaweed, Lessonia trabeculata, harvested in China, to alter the gut microbiota of rats in response to type-2-diabetes. Microwave-assisted methanol extraction was followed by solvent fractionation and macroporous resin adsorption separation. The polyphenol-rich fractions 
produced were composed primarily of phlorotannins, followed by phenolic acids and gallocatechin derivatives. Diabetes was induced in C57BL/6J rats using streptozotocin (STZ). STZ damages the insulin-producing $\beta$ cells of the pancreas, resulting in hypoinsulinaemia and hyperglycaemia. Diabetic rats (8/group) (PE) were fed $200 \mathrm{mg}$ /day polyphenol extract $/ \mathrm{kg}$ BM along with their regular food for 4 weeks. A diabetes control (DC) group and a normal control (NC) group (of non-diabetic rats) received no polyphenol supplement with their food.

Hyperglycaemia, insulin resistance, and hyperlipidaemia were significantly $(p<0.01)$ reduced in the diabetic rats after 4 weeks administration of the seaweed polyphenol extract. Mean fasting blood glucose was lower $(p<0.05)$ in the PE group $(10.55 \pm 0.94 \mathrm{mmol} / \mathrm{L})$ compared to the DC control group $(13.99 \pm 0.87 \mathrm{mmol} / \mathrm{L})$ as was serum insulin $(14.69 \pm 0.11$ vs. $17.70 \pm 0.22 \mathrm{mU} / \mathrm{L}(p<0.01))$. The homeostatic model assessment of insulin resistance (HOMA-IR) value was lower in the PE group $(p<0.01)(6.89 \pm 0.42$ vs. $11.01 \pm 0.98)$ compared to the DC group. The reductions in lipid profiles in the PE group compared to the DC group were: total cholesterol $(4.92 \pm 0.14$ vs. $5.64 \pm 0.16 \mathrm{mmol} / \mathrm{L}(p<0.01))$, triglycerides $(0.99 \pm 0.04$ vs. $1.43 \pm 0.10 \mathrm{mmol} / \mathrm{L}(p<0.01))$, low-density lipoprotein cholesterol $(0.68 \pm 0.03$ vs. $1.06 \pm 0.06(p<0.0))$, glycated serum protein $(2.15 \pm 0.16$ vs. $2.74 \pm 0.15$ $(p<0.01))$ and non-esterified fatty acids $(1.86 \pm 0.05 \mathrm{vs} .2 .02 \pm 0.11 \mathrm{mmol} / \mathrm{L}(p<0.05))$. The dyslipidaemia observed in the DC group who did not receive polyphenol supplementation was most likely due to the deficiency of circulating insulin, which increases lipase activity and fatty acid mobilisation from adipose tissue [211]. 16S rRNA gene sequencing of faecal samples from the diabetic rats revealed that there was a significant $(p<0.01)$ increase in gut bacterial diversity within the polyphenol-fed PE group compared to the DC and NC groups. The PE group had a significantly greater abundance of Bacteroidetes, less Proteobacteria, and an improved (lower) ratio of Firmicutes to Bacteroidetes compared to DC $(p<0.01)$. An overabundance of Proteobacteria has been reported as a pro-inflammatory phylum and linked with the imbalance of glucose homeostasis in type-2-diabetes [170]. At the genus level, the PE group had approximately 10 times more Odoribacter $(p<0.008)$ and Muribaculum $(p<0.005)$, and twice the population of Alistipes $(p<0.006)$, Lachnospiraceae $(p<0.015)$ and Parabacteroides $(p<0.022)$ compared to the DC group. Lachnospiraceae and Alistipes are butyric acid producing bacteria that contribute to the maintenance of colonic epithelial tissue [212]. The Odoribacter genus, part of the Bacteroidetes phylum, is an acetic, propionic and butyric acid producer. Its abundance ameliorates inflammation by increasing SCFA availability [213]. An increase in Muribaculum and Parabacteroides numbers has been reported to combat dyslipidaemia, weight gain, inflammation, and insulin resistance resistance [214,215].

Quantification of gut SCFA showed a $61.1 \%$ increase in total SCFA production (from $491.31 \pm 10.39$ to $1276.34 \pm 16.86 \mu \mathrm{g} / \mathrm{g}(p<0.01))$ by the rats after 4 weeks of polyphenol supplementation. The PE group also produced $68.6 \%$ more acetic acid $(1202.49 \pm 11.55$ compared to $377.77 \pm 3.46 \mu \mathrm{g} / \mathrm{g}(p<0.01))$ and $74.4 \%$ more butyric acid $(39.77 \pm 1.85$ compared to $10.18 \pm 0.58 \mu \mathrm{g} / \mathrm{g}(p<0.01))$ than the DC group. The authors of the study concluded that seaweed polyphenols may have regulated dysbiosis of the gut microbiota in diabetic rats.

2.4.2. Impact of Digestion on Phlorotannin Bioactivity, Attenuation of DNA Damage, and Cancer Cell Proliferation In Vitro

Corona et al. [216] studied the effect of in vitro gastrointestinal digestion and colonic fermentation on the polyphenolic content and bioactivity of high molecular weight (HMW > $10 \mathrm{KDa}$ ) and low molecular weight (LMW 1-10 KDa) ethanol-extracted phlorotannins from A. nodosum harvested in Scotland. To assess changes in phlorotannin bioactivity post-gastric digestion and -fermentation, the ability of the extracts to prevent $\mathrm{H}_{2} \mathrm{O}_{2}$ induced DNA damage in HT-29 colon cancer cells and inhibit cell proliferation was also measured. The HMW extract had the greatest total polyphenol and total phlorotannin contents before and after digestion. The HMW extract also had the highest Trolox equivalent antioxidant capacity. The molecular weight of total phlorotannins before and after gastric digestion 
and colonic fermentation was evaluated by normal phase HPLC. Gastric digestion reduced the level of very high molecular weight components present in the HMW fraction by only $5.4 \%$, while colonic fermentation caused an $89.9 \%$ reduction. In the LMW extracts, gastric digestion reduced the level of very high molecular weight components by $52.8 \%$ and colonic fermentation by $62.0 \%$. In both cases, colonic fermentation had a far greater impact on the breakdown of phlorotannins compared to enzymatic gastric digestion, suggesting that phlorotannins have the potential to be metabolised by human gut bacteria.

A sulforhodamine B assay was used to measure changes in HT-29 colon cancer cell biomass. The addition of post-gastric digested HMW and LMW at a concentration of $500 \mu \mathrm{g} / \mathrm{mL}$ significantly inhibited $(p<0.01)$ HT-29 cell proliferation (number of cells by division), with HMW being the most effective. Post-gastric digested LMW did not inhibit cell growth (mass accumulation) at any concentration, but HMW did $(p<0.05)$ at concentrations of 250 and $500 \mu \mathrm{g} / \mathrm{mL}$. High molecular weight phlorotannins may therefore have a potential protective effect on colonocytes against cancer. $\mathrm{H}_{2} \mathrm{O}_{2}$ induced DNA damage in HT-29 cells was evaluated by single cell gel electrophoresis (Comet) assay. Three of the four phlorotannin extracts (at $100 \mu \mathrm{g} / \mathrm{mL}$ ) were successful in reducing DNA damage. Post-gastric digested HMW significantly $(p<0.01)$ reduced DNA damage compared to the control, while post-gastric digested LMW had no effect. However, both the HMW and LMW post-colonic fermented extracts significantly $(p<0.001)$ reduced DNA damage, suggesting that colonic bacteria may potentially metabolise phlorotannins into molecules with different bioactivity than their parent structures.

Although in vitro studies and animal trials do not replicate the human gut environment identically, these results show that the abundance of bacteria which normally colonise the mammalian gut may potentially be enhanced by the inclusion of dietary polyphenols. The findings are an indication of prebiotic potential, which may be used to inform the design of future human clinical studies. Table 2 summarises the polyphenol used in each study and its potential impact on the gut microbiota in vitro and in vivo, the modulation of hyperglycaemia in animal models, and attenuation of DNA damage in vitro.

Table 2. The potential impact of polyphenols on the gut microbiota in vitro and in vivo, modulation of hyperglycaemia in animal models and DNA damage in vitro.

\begin{tabular}{|c|c|c|c|c|c|}
\hline Polyphenol & Seaweed & Extraction Method & Study Type & Statistically Significant Effects & Ref. \\
\hline $\begin{array}{l}\text { * Phlorotannin } \\
\text { enriched fraction }\end{array}$ & E. radiata & Ethanol (90\%) & $\begin{array}{l}\text { Simulated in vitro } \\
\text { colonic digestion }\end{array}$ & $\begin{array}{l}\text { Increases (all } p<0.05) \text { in } \\
\text { Bacteroidetes }\left(6.52 \pm 0.04 \log _{10}\right. \\
\text { cells } / \mathrm{mL}) \text { compared to the } \\
\text { cellulose control }\left(6.40 \pm 0.05 \log _{10}\right. \\
\text { cells } / \mathrm{mL}) ; \text { F } \text { prausnitzii } \\
\left(6.57 \pm 0.05 \log _{10} \text { cells } / \mathrm{mL}\right) \\
\text { compared to cellulose and inulin } \\
\text { controls }(6.17 \pm 0.04 \text { and } \\
6.07 \pm 0.06 \log _{10} \text { cells } / \mathrm{mL}, \\
\text { respectively); C. coccoides } \\
\left(7.97 \pm 0.05 \log _{10} \text { cells } / \mathrm{mL}\right) \\
\text { compared to inulin and cellulose } \\
\text { controls }(7.57 \pm 0.06 \text { and } \\
7.40 \pm 0.05 \log _{10} \text { cells } / \mathrm{mL}, \\
\text { respectively); and } E . \text { coli } \\
\left(8.09 \pm 0.02 \log _{10} \text { cells } / \mathrm{mL}\right) \\
\text { compared to inulin and cellulose } \\
\text { controls }(6.81 \pm 0.03 \text { and } \\
6.94 \pm 0.03 \log _{10} \text { cells } / \mathrm{mL}, \\
\text { respectively). }\end{array}$ & {$[10]$} \\
\hline
\end{tabular}


Table 2. Cont.

\begin{tabular}{|c|c|c|c|c|c|}
\hline Polyphenol & Seaweed & Extraction Method & Study Type & Statistically Significant Effects & Ref. \\
\hline $\begin{array}{l}\text { ** Polyphenols } \\
(3 \mathrm{kDa}) \text { (luteolin-6-c- } \\
\text { glucoside, regiolone, } \\
\text { neoeriocitrin and estr- } \\
\text { 5(10)-ene-3,17-diol) }\end{array}$ & E. prolifera & $\begin{array}{l}\text { Ultrasound assisted } \\
\text { ethanol extraction } \\
(55 \%) \text { and } \\
\text { ultrafiltration ( } 3 \mathrm{kDa})\end{array}$ & $\begin{array}{l}\text { In vivo trial with } \\
\text { diabetic mice } \\
\text { (4 weeks, } 300 \mathrm{mg} \\
\text { polyphenol } \\
\text { extract/kg BM/day) }\end{array}$ & $\begin{array}{l}\text { Reduction after } 14 \text { days }(p<0.05) \\
\text { in mean BM of E. prolifera-fed } \\
\text { diabetic group compared to } \\
\text { model diabetic group. } \\
\text { Reduction after } 28 \text { days }(p<0.05) \\
\text { in mean fasting blood glucose } \\
\text { levels of E. prolifera-fed diabetic } \\
\text { group and glucose tolerance } \\
\text { increased ( } p<0.05) \text { compared to } \\
\text { the model diabetic group. } \\
\text { Increase in Alistipes }(p<0.05) \text { in } \\
\text { E. prolifera-fed diabetic group } \\
\text { compared to model diabetic } \\
\text { group. } \\
\text { Hypoglycaemic effect via increase } \\
\text { ( } p<0.01) \text { in phosphatidylinositol } \\
\text { 3-kinase and suppression } \\
(p<0.05) \text { of c-Jun N-terminal } \\
\text { kinase in E. prolifera-fed diabetic } \\
\text { group livers compared to model } \\
\text { diabetic group. }\end{array}$ & [170] \\
\hline
\end{tabular}

Increase in genera of the phylum Bacteroidetes in the PE group compared to the DC group:

Odoribacter $(p<0.008)$,

Muribaculum $(p<0.005)$

Alistipes $(p<0.006)$,

Lachnospiraceae $(p<0.015)$ and

Parabacteroides $(p<0.022)$.

Decrease in Proteobacteria, and ratio of Firmicutes to

Bacteroidetes ( $p<0.05$ PE vs. DC group).

Increase in total SCFA

$(491.31 \pm 10.39$ (DC),

$1276.34 \pm 16.86 \mu \mathrm{g} / \mathrm{g}(\mathrm{PE})$

$(p<0.01))$, acetic acid

** Polyphenol-rich fraction (primarily phlorotannins, phenolic acids and gallocatechin derivatives)

\section{L. trabeculata}

Microwave assisted methanol extraction, solvent fractionation and macroporous resin adsorption separation
In vivo trial with diabetic rats (4 weeks, $200 \mathrm{mg} /$ day phlorotannin extract/kg BM)
$(377.77 \pm 3.46$ (DC)

$1202.49 \pm 11.55 \mu \mathrm{g} / \mathrm{g}(\mathrm{PE})$

$(p<0.01))$ and butyric acid

$(10.18 \pm 0.58$ (DC)

$39.77 \pm 1.85 \mu \mathrm{g} / \mathrm{g}$ (PE) $(p<0.01))$.

Reduction in the PE group versus

the DC group in: fasting blood

glucose (10.55 $\pm 0.94 \mathrm{vs}$.

$13.99 \pm 0.87 \mathrm{mmol} / \mathrm{L}(p<0.05))$,

serum insulin $(14.69 \pm 0.11 \mathrm{vs}$.

$17.70 \pm 0.22 \mathrm{mU} / \mathrm{L}(p<0.01))$,

HOMA-IR insulin resistance

value $(6.89 \pm 0.42$ vs. $11.01 \pm 0.98$

$(p<0.01))$, total cholesterol

$(4.92 \pm 0.14$ vs.

$5.64 \pm 0.16 \mathrm{mmol} / \mathrm{L}(p<0.01))$

triglycerides $(0.99 \pm 0.04 \mathrm{vs}$.

$1.43 \pm 0.10 \mathrm{mmol} / \mathrm{L}(p<0.01))$,

LDL cholesterol $(0.68 \pm 0.03$ vs

$1.06 \pm 0.06(p<0.01))$, glycated

serum protein $(2.15 \pm 0.16 \mathrm{vs}$.

$2.74 \pm 0.15(p<0.01))$ and

non-esterified fatty acids

$(1.86 \pm 0.05 \mathrm{vs}$.

$2.02 \pm 0.11 \mathrm{mmol} / \mathrm{L}(p<0.05))$. 
Table 2. Cont

\begin{tabular}{|c|c|c|c|c|c|}
\hline Polyphenol & Seaweed & Extraction Method & Study Type & Statistically Significant Effects & Ref. \\
\hline $\begin{array}{l}\text { (i) * Phlorotannin } \\
\text { (HMW > } 10 \mathrm{kDa}) \\
\text { (ii) Phlorotannin } \\
\text { (LMW 1-10 kDa) }\end{array}$ & A. nodosum & Ethanol & $\begin{array}{l}\text { (a) In vitro } \\
\text { gastrointestinal } \\
\text { digestion and colonic } \\
\text { fermentation } \\
\text { (b) } \mathrm{H}_{2} \mathrm{O}_{2} \text { induced } \\
\text { DNA damage in } \\
\mathrm{HT}-29 \text { colon cancer } \\
\text { cells }\end{array}$ & $\begin{array}{l}\text { (a) Reduction in MW of } \\
\text { phlorotannins ( } 89.9 \% \text { HMW, } \\
62.0 \% \text { LMW) by colonic } \\
\text { fermentation, compared to } \\
\text { enzymatic gastric digestion ( } 5.4 \% \\
\mathrm{HMW}, 52.8 \% \text { LMW), suggesting } \\
\text { phlorotannins may potentially be } \\
\text { metabolised by human gut } \\
\text { bacteria. } \\
\text { (b) Compared to the control, } \\
\mathrm{HMW} \text { and LMW phlorotannin } \\
\text { extracts at a concentration of } \\
500 \mu \mathrm{g} / \mathrm{mL} \text { inhibited ( } p<0.01 \text { ) } \\
\mathrm{HT}-29 \text { colon cancer cell } \\
\text { proliferation (number of cells by } \\
\text { division), } \\
\mathrm{HMW} \text { inhibited ( } p<0.05 \text { ) HT-29 } \\
\text { cell growth (mass accumulation) } \\
\text { at concentrations of } 250 \text { and } 500 \\
\mu \mathrm{m} / \text { mL. } \\
\mathrm{H}_{2} \mathrm{O}_{2} \text { induced DNA damage in } \\
\mathrm{HT}-29 \text { cells reduced by } \\
\text { post-gastric digested HMW } \\
\text { extract ( } p<0.01 \text { and HMW and } \\
\text { LMW post-colonic fermented } \\
\text { extracts (both } p<0.001 \text { ). }\end{array}$ & [216] \\
\hline
\end{tabular}

${ }^{*}=$ in vitro studies; ${ }^{* *}=$ in vivo animal studies

\subsection{Seaweed-Derived Peptides}

Seaweed-derived peptides have reported bioactivity as inhibitors of renin [217], angiotensin converting enzyme-I (ACE-I) [9] dipeptidyl peptidase (DPP-IV) [218], platelet activating factor acetylhydrolase (PAF-AH) [219] and $\alpha$-amylase [220]. They also have reported immunostimulatory [221], antitumor [222], anti-coagulant [223], antioxidative [5], and anti-hyperglycaemic [224] activity. There is recent evidence that some peptides found in vitro correlate with animal studies [225]. A study conducted by Fitzgerald et al. [217] previously identified the potential heart health beneficial effects of peptides included in a bread product with peptides derived from the red seaweed Palmaria palmata using both in vitro and animal models [226]. Peptides were isolated from the seaweed and characterised to completion. However, another study carried out by Allsopp et al. [227] found that the same seaweed had a pro-inflammatory effect when consumed as a whole seaweed in a bread product. This highlights the importance of extraction and characterisation of seaweed bioactives for potential use as therapeutic agents. Allsopp et al. suggested that the iodine content of the seaweed may have been responsible for the observed pro-inflammatory effect in a human dietary intervention study.

Table 3 details the amino acid sequences of recently elucidated seaweed peptides and their bioactivities in vitro, in silico, or in vivo. 
Table 3. Amino acid sequences of recently elucidated seaweed-derived peptides and their bioactivities in vitro, in silico or in vivo.

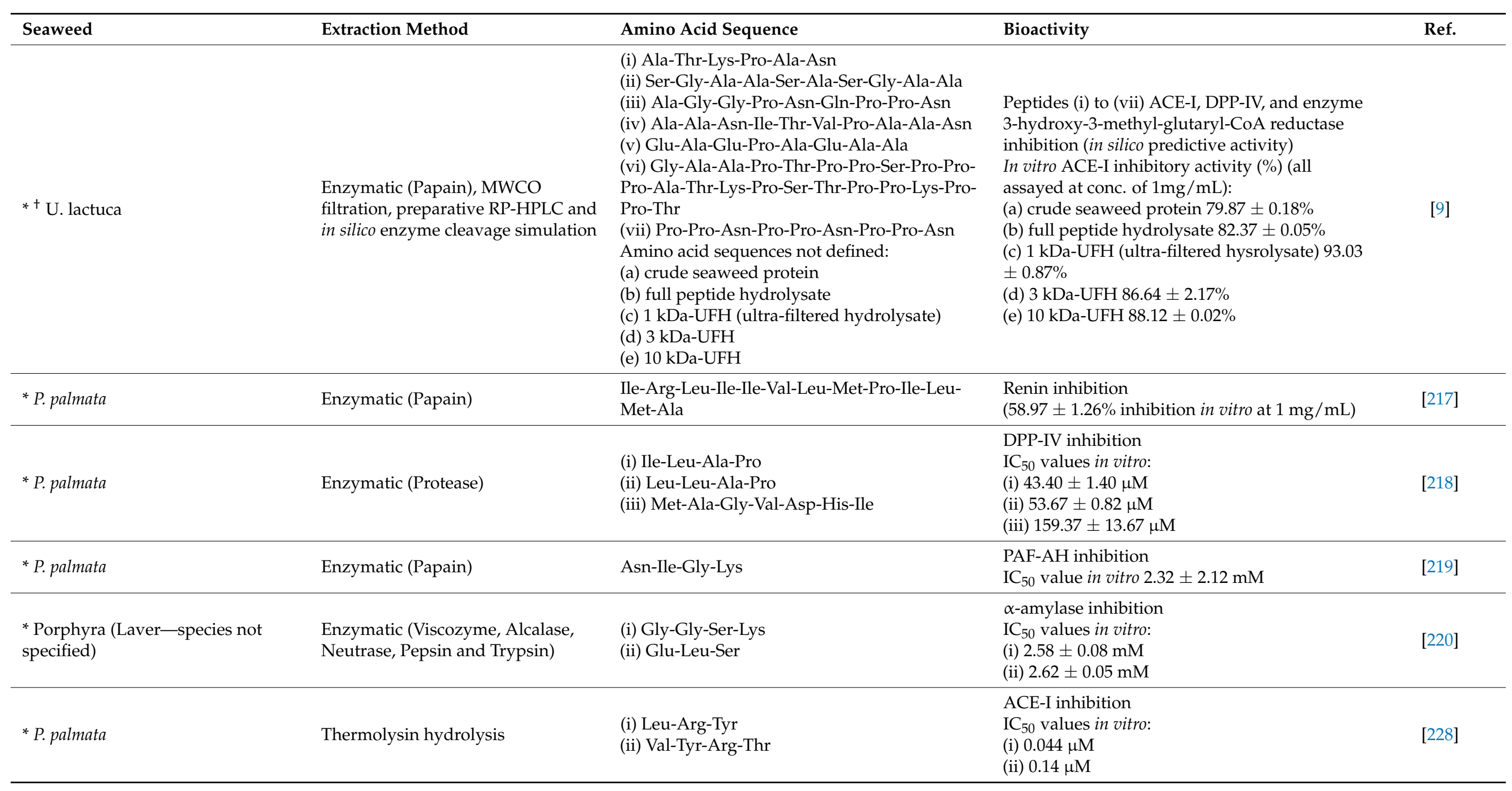


Table 3. Cont.

\begin{tabular}{|c|c|c|c|c|}
\hline Seaweed & Extraction Method & Amino Acid Sequence & Bioactivity & Ref. \\
\hline$* * *$ U. pinnatifida & Enzymatic (Protease) & $\begin{array}{l}\text { (i) Val-Tyr } \\
\text { (ii) Ile-Tyr } \\
\text { (iii) Phe-Tyr } \\
\text { (iv) Ile-Trp } \\
\text { (v) Ala-Trpvi) Val-Trp } \\
\text { (vii) Leu-Trp }\end{array}$ & $\begin{array}{l}\text { ACE-I inhibition } \\
\text { IC } 50 \text { values in vitro: } \\
\text { (i) } 35.2 \mu \mathrm{M} \\
\text { (ii) } 6.1 \mu \mathrm{M} \\
\text { (iii) } 42.3 \mu \mathrm{M} \\
\text { (iv) } 1.5 \mu \mathrm{M} \\
\text { (v) } 18.8 \mu \mathrm{M} \text { (vi) } 3.3 \mu \mathrm{M} \\
\text { (vii) } 23.6 \mu \mathrm{M} \\
\text { I vivo antihypertensive effect in spontaneously } \\
\text { hypertensive rats (single oral dose, } 1 \mathrm{mg} / \mathrm{kg} \text { of } \\
\text { BW). Blood pressure decreases } \\
\text { (pre-administration vs. } 9 \text { h post): } \\
\text { (i) Val-Tyr (228.2 } \pm 3.4 \text { vs. } 206.7 \pm 9.5 \mathrm{mmHg}) \\
(p<0.05) \\
\text { (ii) Ile-Tyr (205.6 } \pm 5.2 \text { vs. } 184.3 \pm 4.5 \mathrm{mmHg}) \\
(p<0.05) \\
\text { (iii) Phe-Tyr (208.7 } \pm 4.4 \text { vs. } 193.0 \pm 5.1 \\
(p<0.01) \\
\text { (iv) Ile-Trp }(213.3 \pm 3.4 \text { vs. } 199.5 \pm 5.9) \\
\text { ( } p<0.05)\end{array}$ & [229] \\
\hline *U. pinnatifida & Enzymatic (Pepsin) & $\begin{array}{l}\text { (i) Ala-Ile-Tyr-Lys } \\
\text { (ii) Tyr-Lys-Tyr-Tyr } \\
\text { (iii) Lys-Phe-Tyr-Gly } \\
\text { (iv) Tyr-Asn-Lys-Leu }\end{array}$ & $\begin{array}{l}\text { ACE-I inhibition } \\
\text { IC }_{50} \text { values in vitro:((i) } 213 \mu \mathrm{M} \\
\text { (ii) } 64.2 \mu \mathrm{M} \\
\text { (iii) } 90.5 \mu \mathrm{M} \\
\text { (iv) } 21.0 \mu \mathrm{M}\end{array}$ & [230] \\
\hline *P. palmata & Enzymatic (Protease) & Ser-Asp-Ile-Thr-Arg-Pro-Gly-Gly-Asn-Met & $\begin{array}{l}\text { Antioxidant activity after simulated } \\
\text { gastrointestinal digestion: } \\
\text { Oxygen radical absorbance capacity } \\
152.43 \pm 2.73 \mathrm{nM} \text { Trolox equivalents } \\
\text { (TE)/ } \mu \text { mol peptide and ferric reducing } \\
\text { antioxidant power activity } 21.23 \pm 0.90 \mathrm{nM} \\
\mathrm{TE} / \mu \text { mol peptide, }\end{array}$ & [231] \\
\hline
\end{tabular}


Proteins and peptides can be used as a food substrate by some families of colonic bacteria including Enterobacteriacea, Burkholderiacea, and Desulfovibrionacea [232] and the genera Peptostreptococcus and Clostridium [233]. Most dietary proteins are broken down by gastric enzymes in the upper gastrointestinal tract and absorbed by the host. The remaining proteins and peptides that reach the colon are metabolised by microbial proteases and peptidases via deamination or decarboxylation reactions to generate amino acids or SCFA, which are used in proteolytic fermentation, or to build microbial cell components $[234,235]$. The majority of microbial protein fermentation occurs in the distal colon, after passing through the proximal colon, where carbohydrate fermentation is dominant. Amino acids cannot be absorbed through the intestinal epithelium in the colon, therefore protein fermentation end-products can accumulate. The majority of protein fermentation end-products are branched-chain amino acids, while some bacteria such as Clostridia and Fusobacteria metabolise peptides into beneficial SCFA [236-239]. Other protein metabolites include hydrogen sulphide, phenylacetate, indoles, ammonia, and p-cresol, an excess of which can impair epithelial barrier function [240]. However, this has only been reported to occur in individuals with low fibre and high protein diets [241], as the availability of complex polysaccharides reduces protein fermentation by the gut microbiota $[242,243]$.

\subsection{Gastrointestinal Digestion Studies with Seaweed Peptides}

Aside from being metabolised into amino acids and beneficial SCFA, seaweed-derived peptides may potentially benefit the gut by enhancing the growth and proliferation of intestinal epithelial cells.

\section{Modulation of Intestinal Epithelial Cell Differentiation}

Lee et al. [244] evaluated the ability of a 20 amino acid peptide extracted from the red seaweed Porphyra yezoensis to modulate cell differentiation in rat intestinal epithelial (IEC-6) cells. Cells were treated with the P. yezoensis peptide (PY-PE) at concentrations of $125,250,500$, and $1000 \mathrm{ng} / \mathrm{mL}$ for $24 \mathrm{~h}$. An MTS tetrazolium assay showed that the PY-PE peptide significantly $(p<0.05)$ induced cell proliferation in a dose-dependent manner. Cells treated with $1000 \mathrm{ng} / \mathrm{mL}$ PY-PE experienced the greatest increase in numbers (65\%). In order to decipher the mechanism by which the peptide exerted this effect, proteins related to the insulin-like growth factor-I receptor (IGF-IR) signalling pathway were measured in the cells. Four main insulin receptor substrate (IRS) proteins are involved in the pathway: IGF-IR, IRS-1, sarcoma homology collagen (Shc), and phosphotyrosine (PY-99). These substrates are adaptor proteins that send signals to the cell nucleus [245]. Protein and mRNA expression of these substrates by the intestinal cells after treatment with PY-PE was evaluated by western blotting, and reverse transcription-polymerase chain reaction (RT-PCR) of complementary (c)DNA. After $24 \mathrm{~h}$, PY-PE successfully upregulated protein and mRNA expression of the four substrates, with the $1000 \mathrm{ng} / \mathrm{mL}$ PY-PE treatment having the most significant $(p<0.05)$ effect.

The IGF-IR pathway in turn activates the mitogen-activated protein kinase (MAPK) signalling pathway. MAPK is a kinase (phosphate transfer enzyme) that binds with threonine and serine and directs cellular responses [246]. Expression levels of three MAPK proteins were measured: extracellular signal-regulated kinase 1/2 (ERK1/2), anti-phosphoc-Jun N-terminal kinase (JNK), and anti-phospho-p38 (P38). Treatment with PY-PE did increase $(p<0.05)$ the expression of ERK1/2 in the intestinal cells in a dose dependent manner; however, the peptide had no effect on JNK or p38. The authors surmised that the peptide only affected ERK1/ 2 expression because it regulates cell growth and proliferation, while JNK and p38 are activated by cellular stress and inflammation.

The effect of PY-PE on the PI3K-Akt signalling pathway was also examined by measuring the intermediates p85, p110, PDK1, and p-Akt. This pathway is involved in cell proliferation and angiogenesis through serine and threonine phosphorylation [143]. Compared to the controls, protein and mRNA expression of p85, p110, PDK1 and p-Akt was 
increased $(p<0.05)$ in intestinal cells treated with PY-PE, dose dependently. Lastly, the p42/p44 mitogen-activated protein kinase (MAPK1) pathway was investigated. This pathway regulates the activation of transcription factors, such as activator protein-1 and its sub-proteins, c-Jun and c-Fos, which modulate cell proliferation and differentiation. Again, PY-PE treatment successfully upregulated protein and mRNA expression of c-Jun and c-Fos in a dose dependent manner.

Due to these positive results, the authors of the study conducted further analysis with the $P$. yezoensis derived peptide [247]. The proliferative effect of the peptide on the epidermal growth factor receptor (EGFR) signalling pathway was investigated in IEC-6 rat intestinal epithelial cells. The EGFR signalling pathway influences cell functions such as proliferation and involves several proteins including phosphorylated (p-)EGFR, Shc, growth factor receptor-bound protein 2 (Grb2) and son of sevenless (SOS) [248]. Treatment with the peptide (125-1000 $\mathrm{ng} / \mathrm{mL}, 24 \mathrm{~h}$ ) increased protein and mRNA expression of p-EGFR, Shc, Grb2 and SOS in the intestinal epithelial cells. As in the previous study, the greatest increases $(p<0.05)$ were induced by the highest concentration of peptide (1000 $\mathrm{ng} / \mathrm{mL})$.

EGFR activates the Ras/Raf-p42/p44 MAPK signalling pathway, which mediates signal transduction from the cell surface to the nucleus [249]. The P. yezoensis peptide increased expression levels of the proteins involved in this pathway: Ras, Raf, mitogen activated extracellular kinase (MEK), and p-extracellular signal-regulated kinase (ERK) compared with the untreated control cells.

The expression of intestinal epithelial cell cycle-related proteins was also examined. After $24 \mathrm{~h}$ treatment with the peptide, expression levels of proteins required for cell proliferation-cyclin D1, cyclin E, Cdk2, Cdk4, Cdk6 and pRb-increased $(p<0.05)$. Conversely, the expression of two other proteins, p21 and p27, decreased following treatment with the peptide. p21 and p27 are cyclin-dependent kinase inhibitors that regulate cell-cycle arrest for the purposes of differentiation, DNA repair, and apoptosis [250]. Although they are required for cell cycle completion, their over-expression has been linked to mucosal damage and ulcerative colitis [251].

Finally, the effect of the $P$. yezoensis peptide on cell cycle progression was measured using flow cytometry during the Gap 1 (G1) phase of cell division. Treatment with the peptide $(1000 \mathrm{ng} / \mathrm{mL})$ induced increases of $47.6,50.6,56.8,62.8$ and $64.4 \%$ following treatment with $0,125,250,500$, and $1000 \mathrm{ng} / \mathrm{mL}$ of peptide, respectively, in the proportion of cells in the G1 phase. The authors concluded from the two studies that the peptide derived from $P$. yezoensis seaweed has potential for development as a bio-functional food which promotes the proliferation of intestinal epithelial cells.

The bioactivity of the $P$. yezoensis peptide was most likely due to the ability of its structure to mimic the substrates of enzymes found in vivo, such as the kinases in the above $P$. yezoensis studies. This is known as enzymatic antagonism. Peptides can inhibit the catalytic action of enzymes on their substrates in a competitive, non-competitive, or uncompetitive manner. Competitive inhibitors can mimic and compete with normal substrates, binding with the active site of the enzyme in their stead. Non-competitive inhibitors bind to allosteric sites on the enzyme, disrupting the conformational arrangement of amino acids at the active site required for activity, thus preventing the substrate from being able to bind. Uncompetitive inhibitors bind to the enzyme-substrate complex, which changes its bioactivity [252]. Several peptides of algal origin have been shown to have chemical structures with the ability to act as enzymatic antagonists $[3,9,253-256]$.

Table 4 summarises the peptide used in each study and significant effects observed in intestinal epithelial cells in vitro. 
Table 4. Seaweed-derived peptides and significant effects observed in intestinal epithelial cells in vitro.

\begin{tabular}{|c|c|c|c|c|}
\hline Peptide & Seaweed & Study Type & Statistically Significant Effects & Ref. \\
\hline $\begin{array}{l}\text { * Ala-Leu-Glu-Gly-Gly-Lys-Ser-Ser- } \\
\text { Gly-Gly-Gly-Glu-Ala-Thr-Arg-Asp- } \\
\text { Pro-Glu-Pro-Thr }\end{array}$ & P. yezoensis & $\begin{array}{l}\text { In vitro rat intestinal epithelial } \\
\text { cells-investigating the modulation of cell } \\
\text { differentiation. }\end{array}$ & $\begin{array}{l}\text { At concentrations of } 125-1000 \mathrm{ng} / \mathrm{mL} \text {, the peptide, } \\
\text { dose-depenently }(p<0.05) \text { : } \\
\text { - Induced intestinal epithelial cell proliferation } \\
\text { - } \quad \text { Upregulated insulin receptor substrates IGF-IR, } \\
\text { IRS-1, Shc and PY-99 } \\
\text { Increased mRNA expression of p110, PDK1, p-Akt, } \\
\text { c-Jun, c-Fos, and MAPK protein ERK1/2 }\end{array}$ & [244] \\
\hline
\end{tabular}




\subsection{Bioaccessibility and Bioavailability}

Bioavailability may be defined as the fraction of ingested nutrient or bioactive compound that reaches the systemic circulation and is utilised by the body [257]. Numerous factors influence the bioavailability of compounds in food including the health status of the individual, age, diet, interactions with other dietary components during digestion, and intestinal and hepatic metabolism $[43,258]$. Bioavailability involves two different phasesbioaccessibility and bioactivity. Bioaccessibility is the quantity of the ingested compound that is released from its food matrix and is available for absorption in the intestine [259]. Bioactivity is the biological activity of a drug or food component and involves transport of the component to the target tissue, interaction with other biomolecules, biotransformation and/or metabolism, and the induction of a physiological response [260].

The oral bioaccessibility of food can be measured in vitro using static or dynamic digestive methods, or ex vivo using organ/tissue culture models. Bioavailability can be measured using an animal-free method such as the protein digestibility-corrected amino acid score for estimating in vivo protein digestibility [261], but is usually measured in vivo using animal or human models [262]. The advantages and limitations of in vitro versus ex vivo and in vivo methods are here outlined.

\subsubsection{In Vitro Bioaccessibility Methods}

In vitro simulated digestion methods are generally used as a preliminary test to determine the oral bioaccessibility of a food-derived component as they can be conducted in a laboratory using chemicals and enzymes that mimic the environment of the stomach and intestine without the need for live animals or human participants [263]. Experimental processes for in vitro simulated digestion involve several incubation steps $(1-3 \mathrm{~h})$ of the sample at physiological temperatures $\left(37^{\circ} \mathrm{C}\right)$ and conditions that simulate the mammalian digestive tract [264]. Oral digestion of the homogenised food sample begins with lingual $\alpha$-amylase at $\mathrm{pH} 5-7$, followed by adjustment of $\mathrm{pH}$ to $1-3$ to mimic the stomach environment and the addition of the endopeptidase, pepsin [36]. Finally, the $\mathrm{pH}$ is adjusted to 6-8 to mimic the small intestine and pancreatin (a combination of amylase, protease, and lipase) is added with or without bile [265].

In vitro methods are divided into four categories: these are solubility, dialysability, gastrointestinal models, and cell models [245].

Solubility and Dialysability

Solubility involves centrifugation of the digested sample and quantification of the nutrient of interest in the supernatant by various techniques such as atomic absorption spectrophotometry (AA), mass spectrometry and HPLC [266]. Laparra et al. [267] estimated the bioaccessibility of arsenic in Hizikia fusiforme, Porphyra and Enteromorpha species using an in vitro solubility method followed by AA.

Dialysability was first described by Miller et al. [268] in 1981 to measure the bioaccessibility of iron by equilibrium dialysis, and has been modified to quantify the bioaccessibility of other micronutrients. After acidic pepsin digestion of the food sample, dialysis tubing of the required MW is filled with a basic buffer such as sodium bicarbonate and added to a vessel containing the sample in its acidic environment. The sodium bicarbonate diffuses out of the dialysis tubing and neutralises the acidity. Pancreatin is added to the sample and incubated. The dialysate that diffuses in through the tubing is the bioaccessible portion of the food sample, which is then removed from the vessel and quantified [268].

\section{Static and Dynamic Gastrointestinal Models}

Gastrointestinal models can be static or dynamic. Static models are the simpler of the two methods and involve the oral, gastric, and small intestinal stages described above. The reactions are carried out in a single bioreactor or flask with stirring and $\mathrm{pH}$ adjustments made at each step by addition of an acid or base, usually hydrochloric acid and sodium hydroxide [260]. One of the limitations of static methods is the broad variance in results 
due to the diversity of reagents used worldwide, particularly digestive enzymes, that differ in activity depending upon their source, which can be human, porcine, rabbit, bacterial, or fungal [269]. Other parameters such as incubation time, $\mathrm{pH}$, ionic strength, the use of phospholipid surfactants, bile salts, and sample to liquid ratio also vary from one method to another [270]. In order to address this lack of cohesion in simulated digestive methods, the European Cooperation in Science and Technology (COST) began an EU-funded Action in 2011 called INFOGEST involving scientists from 45 countries [271]. In 2014, an international consensus was reached and a standardised static in vitro digestion method suitable for food was published by Minekus et al. [269] based on physiologically relevant conditions that can be applied for various endpoints. The method recommends specific concentrations and conditions for each step of static in vitro digestion. Pepsin was determined to be the factor causing most variation, the activity determination of which was found to be improved by $\mathrm{pH}$ stabilisation [269]. Subsequent inter-laboratory validation studies in 2016 by Egger et al. [265] using skim milk powder as a model food found that the harmonised INFOGEST method delivered increased consistency for the comparability of in vitro digestion studies. Recent studies have used the INFOGEST method to evaluate the potential bioaccessibility of seaweed components such as essential minerals [272], carrageenan [273], and to assess protein digestibility [274]. Static models have the advantage of being inexpensive, easy to use, and do not require specific equipment. However, continuous mechanical agitation is not representative of complex peristaltic movements and does not replicate the dynamic processes that occur during digestion, such as continuous changes in $\mathrm{pH}$ and secretions or gastric emptying [275].

Dynamic gastrointestinal models differ from static models in that a series of chambers are used to digest the food sample connected by peristaltic pumps [276]. The temperature, $\mathrm{pH}$, enzyme concentration, incubation time and agitation-rate of each chamber is controlled by a computer [264]. The first commercial dynamic gastrointestinal model was developed in 1995 by Minekus et al. [277] at the Netherlands Organisation for Applied Scientific Research (Toegepast Natuurwetenschappelijk Onderzoek (TNO)) called the TNO GastroIntestinal Model (TIM). The TIM-1 model has four compartments, representing the stomach, duodenum, jejunum, and ileum connected by peristaltic valve pumps. Bioaccessible fractions are collected by dialysis after the fourth compartment [277]. The non-bioaccessible fraction is transferred to the TIM-2 model, which has one compartment representing the large intestine. Human faecal inocula is added to study the effect of colonic fermentation on the food sample and nutrient absorption [277]. The main advantage of the TIM system is that it is a holistic in vitro gastrointestinal model which incorporates the large as well as the small intestine. In addition, samples can be taken at any stage of the digestive process without pausing the experiment [278]. Several studies have found that bioaccessibility results using the TIM system correlate with bioavailability of the same nutrient in vivo. The TIM system was used to measure the bioaccessibility of iron and phosphorus from wheat [279]; folate in folate-fortified milk products [280]; and the bran, flour, and protein aleurone layer of wheat [281] and were found to be comparable to in vivo data. The TIM system has been used to assess the bioaccessibility of heavy metals [282] and essential minerals [283] in seaweed. Drug bioaccessibility was assessed in a study by Blanquet et al. [284] comparing the ability of TIM-1 to measure the bioaccessibility of paracetamol and a lyophilised Lactobacillus strain with in vivo data. The TIM1 results were consistent with in vivo data, showing the value of TIM-1 as a predictive tool on biopharmaceutical behaviour. However, as with all in vitro methods, in vivo factors such as first pass effect, renal clearance, and metabolisation by intestinal epithelial are not represented [284].

The Institute of Food Research in Norwich, England also developed a dynamic method, published by Wickham et al. [285] in 2012, called the Dynamic Gastric Model (DGM). It was designed to simulate the discrete mechanical aspects of gastric digestion as well as the biochemical and is more complex than earlier dynamic models [276]. The masticated sample is added slowly over the course of several minutes to mimic the swallowing of food. The DGM system has several functionally distinct zones in which the masticated 
food bolus is processed to mimic the human stomach environment. A secretion distributer gradually introduces gastric acid and enzymes to the flexible main body around the food bolus, which is then gently kneaded. Contents then move to the antrum, where they are subjected to physiological shear and grinding forces [285]. The sample, or chyme, can be removed at this stage or further digested in the duodenal chamber with pancreatic enzymes, bile salts, lecithin and cholesterol, which is often used for gastro-resistant pharmaceutical formulations to monitor dispersal and dissolution in the duodenal phase [276]. A study by Vardakou et al. [286] compared the disintegration and dissolution capabilities of the DGM system with a standard Dissolution Apparatus USP-II using agar gel beads, and compared the results to those previously observed when the same beads were given to human volunteers [287]. The DGM system was found to be superior to the Dissolution Apparatus USP-II, and there was no significant difference between the human trial data and the DGM, indicating that it is comparable to the mechanical forces exerted by the human gastric digestion [286]. Dynamic gastrointestinal models are more representative of human gastrointestinal digestion because they simulate the changing physicochemical conditions and peristaltic forces of the gastrointestinal tract; however, they are more costly and have lower throughput than static models [264].

Although models concerning digestion and bioaccessibility determination of food bioactives are commonly used in research today, along with colonic digestion methods, they are not always accurate or fully representative of bioactive digestion. This is because every gut has a unique microbiome that cannot currently be replicated in in vitro simulated models. In addition, the gut proteome plays a role in the products available for uptake. However, in vitro simulated models do provide a useful guide concerning the breakdown of foods/food bioactives by enzymes in the stomach and gut. Further development of in vitro static and dynamic models is required to give a true representation of how the microbiome and proteome of the gut impact digestion of seaweed and food bioactives. Comparisons between static, dynamic, colonic and animal studies using pigs are necessary to improve these models [225].

\section{Cell Models}

The fourth category of in vitro methods is the cell culture model. In vitro-differentiated human and other mammalian epithelial cell monolayers that are representative of intestinal epithelial cells can be used to mimic the ability of food components to be absorbed, and actively or passively transported and assimilated across the intestinal epithelium [288]. Cell lines commonly used for bioaccessibility studies include Caco-2, HT-29 [289], GLUTag, murine STC-1, human NCI-H716, [290], and porcine IPEC-J2 [291]. The Caco-2 cell line is a human colon carcinoma cell line which has been extensively used in gastrointestinal studies due to its spontaneous differentiation forming a monolayer of cells, which express several morphological and functional characteristics of the mature enterocyte [292]. Glahn et al. [293] expanded upon the earlier in vitro membrane diffusion method described by Miller et al. [268] by developing a model for assessing bioaccessibility using Caco-2 cells to measure nutrient uptake after simulated peptic and intestinal digestion of casein and various meats. The method was designed to measure iron uptake by cells but can be applied to other micronutrients. The Glahn method overcomes the issue of damage to Caco-2 cells by digestive enzymes. Normally, if a food sample that had been digested in pepsin and pancreatin were added to the media in which cells were growing, the enzymes could digest the protein structure of the cells. The Glahn method utilises a 12,000-14,000 MW cut-off dialysis membrane to allow iron (or other nutrient of interest) to diffuse through onto the cells, while the larger enzyme molecules are held back. The iron that is absorbed by the cells can then be measured. The results using this method parallel human in vivo absorption studies [293]. It has been used recently by Trigo et al. [294] to determine the bioaccessibility of seaweed bioactives. Flores et al. [295] and Domínguez-González et al. [296] also used the Glahn cell culture method to assess the bioavailability of iron and iodine from seaweeds. The lack of mucus production by Caco- 2 cells can be a disadvantage for some studies, 
but may be overcome by co-culturing with a human mucus-producing cell line, such as HT29-MTX to more closely resemble in vivo conditions [288].

In summary, advantages of in vitro methods over ex vivo and in vivo include their low cost, large-scale capacity, high-throughput, and obviation of the need for human volunteers or animal testing, which is more ethical. The major limitation is the absence of the true physiological conditions of the human digestive tract such as peristalsis, phase I/II metabolism, bio-distribution, and renal excretion [262,297]. In vitro methods also do not fully reflect the conditions that affect digestibility in vivo such as interaction of the food sample with other macro- and micro-nutrients, fibre, anti-nutritional components such as phytic acid and lectins, gastric enzyme specificity, and the different absorptive capacities at each stage of the gastrointestinal tract [270,298-300]. In vitro methods offer a good preliminary measure of bioaccessibility, but bioavailability, which has a physiological or metabolic endpoint, cannot be fully quantified by in vitro methods $[263,266]$.

\subsubsection{Ex Vivo Bioavailability Methods}

Ex vivo organ or tissue models are also used to measure the oral bioavailability of bioactive food components. Ex vivo methods use living functional tissues or organs taken from an organism and maintain it in its natural physiological state [301]. The concept was first developed by Ussing [302] in 1946 to measure the active transport of sodium chloride ions in solution across frog skin. This was further developed into the Ussing chamber model, which quantifies the transport of ions, nutrients, or drugs across any epithelial tissue by measuring the potential or voltage difference that is produced as the sample diffuses in solution from one side of the epithelium to the other [303]. For oral bioavailability studies, the required mammalian intestinal mucosal tissue (from duodenum to colon) is mounted between two small chambers of buffered Ringer solution. The compound of interest, along with isotopic tracers, is added to the chamber on the lumenal (apical) side of the epithelium. To mimic haemoglobin delivery by arterial blood, levels of oxygen ( $95 \%$ ) and carbon dioxide (5\%) are maintained [304]. The active transport of the compound of interest by the epithelial cells from lumenal to mucosal side is measured by voltage difference. Interference by passive transport forces such as osmotic and electrochemical gradients is cancelled out by passing an electrical current of zero potential through the epithelium [303]. Advantages of the Ussing chamber model are its precision in measuring the electrical and transport parameters of intact epithelium, and the ability to study any type of intestinal epithelium, as well as others such as the placental barrier [275]. Its main limitations include relatively low-throughput, extensive preparation, short viability (150 $\mathrm{min})$, and limited range of measurements that do not fully describe the complex physiological system of the intestinal mucosa [305].

An intestinal segment model was developed to obtain a higher throughput ex vivo screening system compared to the Ussing chamber model [306]. The intestinal segment model was first described in 1954 by Agar et al. [307] to measure the uptake of histidine by rat intestinal segments. The intestinal segment model measures the absorption of compounds into the intestinal cells rather than their transport through the epithelium [308]. It also involves the use of numerous sections of epithelial tissue which are cut from the original and placed in physiologically balanced solution instead of being mounted, as in the Ussing technique [307]. The porcine ex vivo intestinal segment model is most commonly used due to the physiological resemblance of human and pig intestines [309]. Small circles of tissue segments are punched out and incubated in buffer in 24-wells plates with the test compound. After incubation, the quantity of the test compound absorbed by the intestinal segment is quantified [310]. The intestinal segment model has advantages over the Ussing chamber model in that it is less labour intensive and has a significantly higher throughput [310].

The advantage of ex vivo organ models, in general, over single cell lines is that they are a multi-cell system and therefore more representative of intestinal epithelial behaviour in terms of food absorption [311,312]. Compared to in vivo studies, ex vivo organ models 
remove the need for human participants. Limitations of ex vivo organ models include the lack of inclusion of gut microbial influence and time constraints. The epithelial intestinal tissue must be excised from the animal within $\sim 5$ min of sacrifice, and the viability of intestinal tissues once the experiment begins is only $150 \mathrm{~min}$ and therefore not suitable for many oral bioavailability studies that require more time [313]. The intestinal segment model has the added disadvantage of no distinction between the apical and basolateral side of the epithelium in the way that the mounted Ussing model does, as the segments are completely submerged in the same solution on both sides [314].

\subsubsection{In Vitro Fermentation Models}

In vitro fermentation models allow the impact of gut microbial populations on food bioaccessibility and bioactivity to be studied without using invasive human or animal methods. Batch or dynamic fermentation models can be used [315]. Batch fermentation models entail the use of a sealed vessel under anaerobic conditions containing the food sample or extract of interest in sterile media to which is added either a pure, or mixed, bacterial culture or faecal slurry, fermented for $\sim 2$ to $24 \mathrm{~h} \mathrm{[316].} \mathrm{The} \mathrm{advantage} \mathrm{of} \mathrm{batch}$ models is that they are simple to set up and inexpensive, however, since it is a static sealed model, fermentation products such as SCFA can accumulate, and there is a finite amount of substrate available for the bacteria, all of which can affect the fermentation environment [316]. Dynamic multistage models can be used to overcome this issue. In 1988, Gibson et al. [317] first described a three-stage continuous culture system with a mixed human faecal inocula fermented over 120 days that represented the environment of the proximal, transverse and distal colon. Since the 1980s, more sophisticated, computerised dynamic models have been developed including the TIM-2 (previously discussed), The Simulator of the Human Intestinal Microbial Ecosystem (SHIME ${ }^{\circledR}$ ) and SIMulator of the GastroIntestinal tract (SIMGI).

The SHIME model is a 5-step multi-chamber bioreactor developed by Molly et al. [318] in 1993 that simulates the entire digestive tract from stomach to colon. The SHIME system involves allowing the microbial inoculum acclimate for 14 to 20 days to produce an environment that is representative of the in vivo colon in terms of bacterial populations and SCFA production [319]. Two advanced models have been developed from the original SHIME system-TWIN-SHIME and M-SHIME. Possemiers et al. [320] devised the first TWIN-SHIME model, which involves running two parallel SHIME reactors, making it possible to assess the impact of different diets or antibiotics on the same gut microbiota, as well as the metabolism and bioaccessibility of nutrients, and the pre- and probiotic effect of selected foods or microorganisms. Van den Abbeele et al. [321] incorporated mucincovered microcosms in the M-SHIME model to create a more realistic microbial community of mucosal microbes such as Lactobacillus mucosae and Pediococcus acidilactici that are normally present on the gut epithelium. The SHIME model was used by Marzorati et al. [322] to investigate the potential of fucoidan to modulate a gut bacterial community, and by Fu et al. [323] and Calatayud et al. [324] to evaluate the effect of gut microbiota on the bioaccessibility of arsenic from the seaweeds Hizikia fusiforme and nori.

Advantages of SHIME include realistic representation of the upper and lower digestive tracts rather than the colon alone; long-term stability of the microbiome, which can be assessed as it adapts; option to set the model to parameters found in diverse groups such as humans, animals, diseased, healthy, elderly, or infants (Baby-SHIME) [325]; parallel comparison of alternate treatments (TWIN-SHIME); and ability to create a luminal or a mucosal microbiome (M-SHIME) [318,326,327]. Limitations of the SHIME model include a lack of realistic peristalsis, expensive set-up costs, and absence of a dialysis component and mucosal cells (in the original model) [326].

The SIMGI multicompartmental dynamic model is another five-chamber system that represents the entire human intestinal tract, developed by Barroso et al. [328] in 2015. It differs from other dynamic models in that the contents of the stomach chamber are mixed by peristaltic movements. Two rigid outer chambers surround an inner unit with flexible 
silicone walls. Alternating the pressure of the water flow between the outer chambers and inner unit creates a realistic simulation of gastric peristalsis [329]. The SIMGI system has the same advantages and limitations as the original SHIME model. However, SIMGI has the unique advantage of the inclusion of simulated peristalsis that is not found in SHIME or any other dynamic models, creating a more mechanically realistic stomach environment [329].

Overall, the advantage that all dynamic models have over static models is that they more closely represent the human gut because $\mathrm{pH}$ and nutrient availability within each chamber are controlled throughout the fermentation process, which also allows for much longer experiments than static batch models [330]. Dynamic models have good experimental stability and reproducibility [331]. Samples can be taken from each chamber during fermentation to assess changes in bacterial populations and their metabolites, and the ethical constraints that limit in vivo trials are absent [332]. Limitations of dynamic models include the lack of intestinal epithelial and immune cells in some systems; lack of hostmicrobe interplay [333]; no feed-back mechanisms in the system; and the use of parameters such as $\mathrm{pH}$, redox potential, and transit time based on healthy individuals which may not be representative of many groups [334].

\subsubsection{In Vivo Bioavailability Methods}

The most accurate method for measuring the bioavailability of a food component is in vivo evaluation [335]. In vitro and ex vivo methods provide very useful data on bioaccessibility, and to a certain extent, bioavailability if cell models are used but they can never fully express the digestive fate of a food component in a living person or animal. This is primarily due to the complex metabolism that occurs during absorption, where food metabolites reaching the blood system may be different from the original compounds [336]. Bioavailability involves the phases of liberation, absorption, metabolism, tissue distribution, bioactivity, and elimination [257]. Balance studies can be used to measure the oral bioavailability of a nutrient by the amount that is eliminated. This entails the collection of all urine and stools after giving a known amount of the nutrient to test subjects over several days or weeks [337]. Balance studies provide accuracy, but are laborious and more suited to laboratory animal models than human subjects [338]. Tissue distribution studies also provide bioavailability data on the extent of absorption, but are almost exclusively conducted on animals due to the invasive nature of the procedure [339,340]. In human in vivo studies, the oral bioavailability of a bioactive food component is most commonly measured by analysis of its metabolites in blood plasma and/or urine after a single dose, or controlled long-term consumption [336,341]. These are the methods used in the seaweed bioavailability studies discussed in the following sections.

Although in vivo studies are considered the gold standard for assessing the oral bioavailability of food components [263] some disadvantages exist. Compared to in vitro and ex vivo models, obtaining ethical approval for in vivo studies is far more difficult due to the potential harm that may be caused to animal or human participants, and in many cases, the necessary sacrifice of animal subjects [43]. In vivo studies are generally more expensive and time-consuming than other methods [342] and are not suitable for highthroughput screening of bioavailability [343]. It is more difficult to control all variables in vivo because of naturally occurring differences in living organisms, which can affect the reliability of results [344]. In vivo trials involving small cohorts may not be reflective of the bioavailability of a nutrient in the wider population [345].

However, these limitations are ultimately outweighed by the advantages. In vivo studies reflect the complete effect of digestion, first pass metabolism, Phase I/II biotransformation, host microbiota, and fermentation on an orally consumed nutrient [43,257]. In addition, in vivo studies show the impact of the nutrient on the body as a whole, rather than in one localised area or on one particular biological process [342]. Data from in vivo studies is more clinically relevant and any side-effects induced by the consumed sample can be observed [262,346]. Although gaps exist in in vitro methods of measuring digestion 
and bioavailability compared to animal models, in vitro studies still provide very relevant and useful data regarding bioaccessibility.

Table 5 summarises the advantages and limitations of each gastrointestinal digestion model system.

Table 5. Advantages and limitations of gastrointestinal (GI) digestion model systems.

\begin{tabular}{llll}
\hline In Vitro Bioaccessibility Methods & Advantages & Limitations \\
\hline & $\bullet$ & $\begin{array}{l}\text { Simple and inexpensive to conduct with } \\
\text { enzymes and dialysis filters that chemically } \\
\text { mimic oral, gastric and small intestinal }\end{array}$ & $\begin{array}{l}\text { Does not represent peristaltic movements, } \\
\text { sigection }\end{array}$ \\
Solubility and Dialysability & $\begin{array}{l}\text { Inexpensive } \\
\text { tract }\end{array}$ & No gut microbial component \\
& $-\quad$ No human or animal subjects required &
\end{tabular}

- Simple to conduct in single bioreactor or flask with stirring and $\mathrm{pH}$ adjustments

Static GI models

- Inexpensive

- No human or animal subjects required

- $\quad$ Broad variance in results due to reagent diversity, particularly digestive enzymes which differ in activity dependent on their source (human, porcine, rabbit, bacterial, or fungal)

- Continuous mechanical agitation is not representative of complex peristaltic movements, secretions, or gastric emptying of the GI tract

- No gut microbial component

- Addresses worldwide lack of cohesion in simulated digestive methods

- $\quad$ Standardised static method suitable for food based on physiologically relevant conditions which can be applied for various endpoints

INFOGEST static in vitro model

- $\quad$ Pepsin determined to be the factor causing most variation-activity determination may be improved by $\mathrm{pH}$ stabilisation

- Inexpensive

- No human or animal subjects required
- Holistic in vitro gastrointestinal model incorporating the large and small intestine

- More representative of human GI digestion as changing physicochemical conditions and peristaltic forces are simulated in functionally distinct zones

- Human faecal inoculum included to study

Dynamic GI models the effect of colonic fermentation on the food sample and nutrient absorption

- Samples can be taken at any stage of the digestive process without pausing the experiment

- $\quad$ Bioaccessibility results of dynamic models have been shown to correlate with bioavailability of the same nutrient in vivo

- No human or animal subjects required
- Continuous mechanical agitation is not representative of complex peristaltic movements, secretions, or gastric emptying of the GI tract

- No gut microbial component
- More costly and lower throughput than static models

- $\quad$ Lack of in vivo factors such as first pass effect, renal clearance, and metabolisation by intestinal epithelial cells. 
Table 5. Cont.

\begin{tabular}{|c|c|c|}
\hline In Vitro Bioaccessibility Methods & Advantages & Limitations \\
\hline Cell models & $\begin{array}{l}\text { - } \quad \text { Representative of intestinal epithelial cells } \\
\text { Parallels human in vivo absorption studies } \\
\text { May be used to mimic the ability of food } \\
\text { components to be actively or passively } \\
\text { transported and assimilated across the } \\
\text { intestinal epithelium } \\
\text { Human cell lines can be used as well as } \\
\text { animal cells } \\
\text { Mucus-producing cell lines can be } \\
\text { co-cultured to more closely resemble in vivo } \\
\text { conditions }\end{array}$ & $\begin{array}{l}\text { - Time-consuming to culture cell lines } \\
\text { - } \quad \text { First pass effect, renal clearance, interaction } \\
\text { of the food sample with other nutrients } \\
\text { and anti-nutrients, and different absorptive } \\
\text { capacities at each stage of the } \\
\text { gastrointestinal tract are not represented }\end{array}$ \\
\hline Ex vivo bioavailability methods & $\begin{array}{l}\text { Multi-cell systems are more representative of } \\
\text { intestinal epithelial behaviour in terms of } \\
\text { food absorption than single cell lines } \\
\text { Animal organ or tissue models can measure } \\
\text { the oral bioavailability of bioactive food } \\
\text { components } \\
\text { Mimics arterial blood haemoglobin delivery } \\
\text { by maintaining oxygen and carbon dioxide } \\
\text { levels } \\
\text { - Precise measurement of electrical and } \\
\text { transport parameters of intact epithelium } \\
\text { Any type of intestinal epithelium from } \\
\text { duodenum to colon can be studied, as well as } \\
\text { other epithelia, such as the placental barrier } \\
\text { No human subjects required }\end{array}$ & $\begin{array}{l}\text { - } \quad \text { Extensive preparation } \\
\text { - } \quad \text { Low throughput (mounted tissue models, } \\
\text { such as Ussing chambers) } \\
\text { Intestinal segment models have greater } \\
\text { throughput, but no distinction between } \\
\text { apical and basolateral side of the } \\
\text { epithelium as tissue segments are fully } \\
\text { submerged } \\
\text { Short viability-epithelial intestinal tissue } \\
\text { must be excised from animal within } \sim 5 \\
\text { min of sacrifice } \\
\text { Viability of intestinal tissues once the } \\
\text { experiment begins is only } \sim 150 \text { min and } \\
\text { not suitable for many oral bioavailability } \\
\text { studies that require more time } \\
\text { Limited range of measurements that do not } \\
\text { fully describe the complex physiological } \\
\text { system of the intestinal mucosa }\end{array}$ \\
\hline
\end{tabular}

- $\quad$ Static batch or dynamic fermentation models can be used

- $\quad$ Batch models are simple to set up and inexpensive

- $\quad$ Evaluates the impact of gut microbial populations on food bioaccessibility and bioactivity without using invasive human or animal methods

- Dynamic multistage models overcome the issue of fermentation product build-up in static batch models. $\mathrm{pH}$ and nutrient availability within each chamber are controlled throughout fermentation

- Computerised dynamic models such as TIM-2, SHIME and SIMGI create an anaerobic environment representative of the upper and lower digestive tracts rather than the colon alone in terms of bacterial populations and SCFA production

- Long-term stability of the microbiome-can be assessed as it adapts

- $\quad$ SHIME has option to set parameters found in diverse groups-humans, animals, diseased, healthy, elderly, or infants, and compare alternate treatments in parallel

- $\quad$ Possible to create a luminal or a mucosal microbiome

- Easier to obtain ethical approval compared to in vivo studies
- Dynamic multistage models are costly and complex to set-up

- In static sealed batch models, fermentation products such as SCFA and p-cresol can accumulate and there is a finite amount of substrate available for the bacteria

- $\quad$ Lack of realistic peristalsis; expensive set-up costs; and absence of a dialysis component and mucosal cells (in the original SHIME model)

- $\quad$ Lack of realistic peristalsis in SHIME model and absence of a dialysis component and mucosal cells (in the original model)

- $\quad$ Lack of intestinal epithelial and immune cells in some systems. No feed-back mechanisms

- Use of parameters such as $\mathrm{pH}$, redox potential, and transit time based on healthy individuals may not be representative of many groups 
Table 5. Cont.

\begin{tabular}{|c|c|c|}
\hline In Vitro Bioaccessibility Methods & Advantages & Limitations \\
\hline In vivo bioavailability methods & $\begin{array}{l}\text { - } \quad \text { Considered the gold standard and most } \\
\text { accurate method for measuring } \\
\text { bioavailability - analysis of metabolites in } \\
\text { blood plasma and/or urine after a single } \\
\text { dose, or controlled long-term consumption } \\
\text { Reflects complete effect of digestion, first } \\
\text { pass metabolism, Phase I/II } \\
\text { biotransformation, host microbiota and } \\
\text { fermentation on an orally consumed nutrient } \\
\text { - } \quad \begin{array}{l}\text { Balance studies collecting urine and stools to } \\
\text { measure oral bioavailability are accurate }\end{array} \\
\text { Tissue distribution studies provide } \\
\text { bioavailability data on the extent of } \\
\text { absorption } \\
\text { Data from in vivo studies is more clinically } \\
\text { relevant and any side-effects induced by the } \\
\text { consumed sample can be observed }\end{array}$ & $\begin{array}{l}\text { Balance studies are laborious and more } \\
\text { suited to laboratory animal models than } \\
\text { human subjects } \\
\text { Tissue distribution studies almost } \\
\text { exclusively conducted on animals due to } \\
\text { invasive nature } \\
\text { - } \quad \text { Difficult to obtain ethical approval due to } \\
\text { potential harm to animal or human } \\
\text { participants and sacrifice of animals } \\
\text { Usually more expensive and } \\
\text { time-consuming than other methods } \\
\text { Not suitable for high-throughput screening } \\
\text { of bioavailability } \\
\text { More difficult to control all variables due } \\
\text { to naturally occurring differences in living } \\
\text { organisms } \\
\text { In vivo trials involving small cohorts may } \\
\text { not be reflective of the bioavailability of a } \\
\text { nutrient in the wider population }\end{array}$ \\
\hline
\end{tabular}

A number of recent studies have evaluated the bioaccessibility of seaweed-derived polysaccharides, polyphenols, and peptides after ingestion in human and animal subjects and are discussed below.

\subsubsection{Bioaccessibility of Seaweed Polysaccharides}

Gueven et al. [347] showed that a single dose of orally ingested fucoidan is sufficient to affect the expression of genes related to immunity, inflammation, cancer, and neurological function. A placebo-controlled double-blind study was performed in nine healthy, male volunteers (age $25-65$ years-old). Fucoidan $(85.1 \%$ pure, MW $47.7 \mathrm{kDa}$ ) was water-extracted from U. pinnatifida harvested in Tasmania. A capsule containing $1 \mathrm{~g}$ seaweed extract (851 mg fucoidan) or a cellulose placebo was administered. Blood was taken immediately before and $24 \mathrm{~h}$ after ingestion. 754 micro RNA (miRNA) strands were isolated and analysed as biomarkers of physiological function. Fucoidan ingestion was found to affect 53 miRNAs. Fifteen were upregulated and 38 downregulated. Only one upregulated and five downregulated miRNAs were common to both the placebo and fucoidan groups. The pathways and processes affected by the identified miRNAs are associated with cell surface receptor signalling, the enhancement of brain-derived neurotrophic factor, epidermal growth factor receptor, insulin receptors, and the associated MAPK downstream signalling.

Ikeda-Ohtsubo et al. [348] evaluated the in vivo modulatory effects of fucoidan on the gut microbiota in an animal model. Fucoidan ( $>95 \%$ pure, MW $49.8 \mathrm{kDa}$ ) was extracted from Cladosiphon okamuranus (Okinawa mozuku) harvested in Japan. Adult zebrafish had their food supplemented (1:1) with fucoidan for 3 weeks. The presence of pro- and anti-inflammatory cytokines was determined by quantitative (q)PCR. Then, 16S rRNA sequencing was used to analyse changes in the microbiota. There was a significant decrease in expression levels of the pro-inflammatory cytokine IL-1 $\beta$ in the fucoidan-fed zebrafish compared to the control. In terms of beneficial changes to the microbiota, fucoidan feeding significantly enhanced the diversity and composition of intestinal bacterial. Bacteria of the families Rhizobiaceae (genus Shinella) and Comamonadaceae (genus unclassified) became dominant at the expense of E. coli-related Enterobacteriaceae. Intestinal Enterobacteriaceae have been reported to have pro-inflammatory effects [349]. The reduction in Enterobacteriaceae after fucoidan supplementation may have been responsible for the downregulation of the pro-inflammatory cytokine IL- $1 \beta$. This illustrates the potential modulatory role of seaweed polysaccharides in the diet-microbiota-host interplay.

Fucoidan extracted from Japanese Okinawa mozuku was also shown to be bioaccessible to rats fed $2 \%$ fucoidan-supplemented food for 8 weeks [350]. Immunohistochemical 
staining revealed that fucoidan had been absorbed across the intestinal epithelium and taken up by intestinal macrophages and hepatic Kupffer cells. The same research group went on to investigate factors concerning the absorption of the Okinawa mozuku-derived fucoidan in a cross-sectional human study $(n=396)$ by Kadena et al. [351]. Okinawa mozuku is a species of brown seaweed endemic to a small group of islands south of the Japanese mainland called the Okinawa prefecture or region. Of the study population, $68 \%$ were native to Okinawa, while $32 \%$ were from other regions of Japan. Participants (227 male, 169 female, age 20 to $>70$ years-old) were administered a drink of $3.75 \mathrm{~g}$ mozuku extract (containing $3 \mathrm{~g}$ pure fucoidan) in $200 \mathrm{~mL}$ purified water. The fucoidan had an average MW of $73.4 \mathrm{kDa}$ and a composition of $51.2 \%$ L-fucose, $14.4 \%$ uronic acid, and $18.8 \%$ sulphate. Participants refrained from consuming seaweed or fucoidan supplements the day before and throughout the day of trial. Urine samples were collected before administration and 3,6, and $9 \mathrm{~h}$ after. The presence of fucoidan was measured using a purpose-designed ELISA [352]. The assay antibody was specific to fucoidan and did not react with other sulphated polysaccharides. Fucoidan concentration was expressed as a corrected urinary creatinine value $(\mu \mathrm{g} / \mathrm{gCr})$ as fucoidan was calculated to be equivalent to one eighth of urinary excreted creatinine.

The results showed that intestinal absorption of Okinawa mozuku-derived fucoidan occurred in $97 \%$ of study participants (385 of 396). There was a highly significant difference $(p<0.01)$ in fucoidan absorption in native Okinawa participants compared to those from other regions. Eight of the 11 participants who did not excrete fucoidan lived outside Okinawa. After $9 \mathrm{~h}$, the total mean urinary fucoidan content of native Okinawa participants $(332.3 \mu \mathrm{g} / \mathrm{gCr})$ was $38.4 \%$ greater $(p<0.01)$ than those from other regions $(240.1 \mu \mathrm{g} / \mathrm{gCr})$. Of the group, $87.5 \%$ that excreted the highest levels fucoidan $(>1200 \mu \mathrm{g} / \mathrm{gCr})$ were native to Okinawa. By age bracket, participants in their $40 \mathrm{~s}$ had the greatest mean urinary fucoidan value $(392.8 \mu \mathrm{g} / \mathrm{gCr})$. The authors hypothesised that the gut bacteria of native Okinawa participants may have acquired genes from marine bacteria that produce the digestive enzyme fucoidanase. This horizontal transfer of genes from ocean-dwelling bacteria that normally colonise and feed on seaweed has previously been reported in populations that have consumed seaweed for thousands of years [353-357].

\subsubsection{Bioaccessibilty of Seaweed Polyphenols}

Human clinical studies on the bioaccessibility of seaweed polyphenols are limited to brown species, and phlorotannins in particular. Table 6 summarises the polyphenol used in each study and the impact of digestion on their bioaccessibilty. 
Table 6. Bioaccessibility of seaweed polyphenols.

\begin{tabular}{|c|c|c|c|c|c|}
\hline Seaweed & Polyphenol & Extraction Method & Study Type & Observed Effects & Ref. \\
\hline${ }^{*}{ }^{* * *}$ A. nodosum & Phlorotannins & $\begin{array}{l}\text { Ethanolic crude phlorotannin } \\
\text { extract (CE) and } \\
\text { high-molecular-weight (HMW) } \\
\text { fraction ( }>10 \mathrm{kDa}) \text { by tangential } \\
\text { flow ultrafiltration. Combined as } \\
\text { CE }(58 \%) \text { and HMW }(42 \%)\end{array}$ & $\begin{array}{l}\text { (i) In vitro gastrointestinal enzymatic } \\
\text { digestion, colonic fermentation, and } \\
\text { dialysis to simulate absorption into the } \\
\text { bloodstream. } \\
\text { (ii) Cross-sectional human clinical trial } \\
\text { (12 male, } 12 \text { female, healthy } \\
18-65 \text { years-old) (one capsule } 101.89 \mathrm{mg} \\
\text { phlorotannins). Blood and urine } \\
\text { collected ( } 0 \text { to } 24 \mathrm{~h} \text { ). }\end{array}$ & $\begin{array}{l}\text { Phlorotannin metabolites } \\
\text { detected in } 15 \text { of } \\
24 \text { participants after } 24 \mathrm{~h} \\
\text { (total phlorotannins ranged } \\
\text { from } 0.011-7.76 \mu \mathrm{g} / \mathrm{mL} \text { in } \\
\text { blood plasma and from } \\
0.15-33.52 \mu \mathrm{g} / \mathrm{mL} \text { in urine). }\end{array}$ & [206] \\
\hline${ }^{* * *}$ A. nodosum & Phlorotannins & $\begin{array}{l}\text { Ethanol CE extract and HMW } \\
\text { fraction }(>10 \mathrm{kDa}) \text { by tangential } \\
\text { flow ultrafiltration. Combined as } \\
\text { CE }(57 \%) \text { and HMW }(43 \%)\end{array}$ & $\begin{array}{l}24 \text { week crossover study ( } 8 \text { weeks, } \\
100 \text { mg phlorotannin/d, or placebo } \\
\text { capsule) ( } 39 \text { men, } 41 \text { women, mean BMI } \\
30.2, \text { mean age } 42.7 \text { years-old), } 8 \text { weeks } \\
\text { washout phase, then repeat } 8 \text { weeks } \\
\text { intervention or placebo treatment. } \\
\text { Plasma and urine collected before/after } \\
\text { each phase }(0,8,16 \text { and } 24 \text { weeks). }\end{array}$ & $\begin{array}{l}\text { Polyphenol metabolites } \\
(0.5-11.8 \mathrm{mg} / \text { day total } \\
\text { polyphenols }) \text { detected in } 36 \\
\text { of } 78 \text { participants. }\end{array}$ & [358] \\
\hline
\end{tabular}

\footnotetext{
${ }^{*}=$ in vitro studies; ${ }^{* * *}=$ human dietary intervention studies.
} 
These studies, along with others that have assessed the bioaccessibilty of polyphenols from terrestrial plants, have a commonality in that oral bioaccessibilty of polyphenols in some individuals is poor. There are a number of reasons for this, such as host-related factors. These can be systemic factors including age, gender, genetics, and existing health disorders; or intestinal factors, such as gastric enzyme activity, intestinal transit time, and gut microflora composition intestinal factors such as gastric enzyme activity, intestinal transit time, and gut microflora composition [359]. The food matrix in which polyphenols are consumed and interactions with macronutrients impact bioaccessibility. In the digestive tract, the amine group of proteins can form irreversible covalent bonds with the carboxylic group of polyphenols [360], which interferes with the ability of digestive enzymes to catabolise them. Since enzymes are proteins, polyphenols also interact with their amine groups, further inhibiting digestion. [361,362]. The capacity for polyphenols to bind with proteins increases with their molecular weight. Some seaweed polyphenols, such as phlorotannins, have a MW of up to $100 \mathrm{kDa}$ [363], making them suitable candidates for multiple protein-polyphenol interactions.

Lipids have been shown to enhance polyphenol bioaccessibilty. Hydrophobic interactions between lipids and polyphenols have a protective effect and increase the stability of polyphenols during digestion [364]. Complexing with lipids can also increase the accumulation of polyphenols in the liver, which acts as a slow-release reservoir that prolongs their residence time in the blood [365]. Polysaccharides, in the form of dietary fibre, can bind with polyphenols. The hydroxyl groups of polyphenols form hydrogen bonds with the oxygen atoms of polysaccharide glycosidic linkages [366] or covalent bonds, such as esters [367]. While this reduces the ability of gastric enzymes to make them bioaccessible in the upper gastrointestinal tract, polyphenols can be released from their non-digestible polysaccharide complex in the colon through the action of gut microbial digestive enzymes [368]. In fact, polysaccharides such as alginate have been used to encapsulate polyphenols, delaying their release until they reach the colon [369].

Despite their low oral bioaccessibility, the biological activity of polyphenols is generally found to be high, leading to a low bioaccessibility/high bioactivity paradox. This is most likely due to the biotransformation of polyphenols in the liver and enterocytes mediated by phase I cytochrome P450 enzymes and phase II conjugation enzymes (uridine 5'-diphospho-glucuronosyltransferase and sulphotransferase) [343]. Phase I and II biotransformation is a detoxification system that modifies compounds that the body perceives as xenobiotics for easier excretion via urine, faeces, and bile [370]. This biotransformation results in conjugated compounds with different polarity, MW, ionic form, and greater intrinsic biological effects than their parent compounds [371,372]. After compounds such as polyphenols are conjugated, they re-enter the gastrointestinal tract in bile via enterohepatic recirculation [373]. Gut bacterial enzymes, particularly $\beta$-glucuronidase, can metabolise many of these polyphenol conjugates, further modifying their chemical structure, bioactivity, and bioavailability [341]. This enterohepatic recycling prolongs the presence of polyphenols within the body. Therefore, the limited oral bioaccessibilty of seaweed polyphenols does not determine their ultimate bioactivity. The biotransformation of native polyphenols through the action of digestive enzymes and microbial fermentation produces metabolites with disparate bioaccessibilty and bioactivity.

\subsubsection{Bioaccessibility of Seaweed Peptides}

There is a dearth of literature on the in vivo bioaccessibility of seaweed-derived peptides in human studies; however, some in vivo studies have reported the effect of digestion on their bioactivity in animal models or in vitro. Table 7 summarises the peptide used in each study and the impact of digestion on their bioactivity. 
Table 7. Bioactivity of seaweed peptides.

\begin{tabular}{|c|c|c|c|c|c|}
\hline Seaweed & Peptide & Extraction Method & Study Type & Statistically Significant Effects Post-Digestion & Ref. \\
\hline ** U. pinnatifida & $\begin{array}{l}\text { (i) Tyr-His } \\
\text { (ii) Lys-Tyr } \\
\text { (iii) Phe-Tyr } \\
\text { (iv) Ile-Tyr }\end{array}$ & Hot water & $\begin{array}{l}\text { In vivo study in spontaneously } \\
\text { hypertensive rats. } \\
\text { (a) Single oral administration of each } \\
\text { dipeptide }(50 \mathrm{mg} / \mathrm{kg} \mathrm{BM}) \\
\text { (b) Continuous administration for } \\
7 \text { days }(10 \mathrm{mg} / \text { day } / \mathrm{kg} \mathrm{BM})\end{array}$ & $\begin{array}{l}\text { (a) All dipeptides decreased }(p<0.05) \text { blood pressure after single } \\
\text { oral dose: } \\
\text { i. Tyr-His decreased } 50 \mathrm{~mm} \mathrm{Hg} \text { after } 3 \mathrm{~h} \\
\text { ii. Lys-Tyr decreased } 45 \mathrm{~mm} \mathrm{Hg} \text { after } 6 \mathrm{~h} \\
\text { iii. Phe-Tyr decreased } 46 \mathrm{~mm} \mathrm{Hg} \text { after } 3 \mathrm{~h} \\
\text { iv. IleTyr decreased } \mathrm{Hg} 33 \mathrm{~mm} \mathrm{Hg} \text { after } 3 \mathrm{~h} \\
\text { (b) After } 7 \text { days continuous oral administration blood pressure } \\
\text { was lowered (all } p<0.05 \text { compared to pre-adminstraton): } \\
\text { i. Tyr-His decreased } 34 \mathrm{~mm} \mathrm{Hg} \\
\text { ii. Lys-Tyr decreased } 26 \mathrm{~mm} \mathrm{Hg} \\
\text { iii. Phe-Tyr decreased } 34 \mathrm{~mm} \mathrm{Hg} \\
\text { iv. IleTyr decreased } 25 \mathrm{~mm} \mathrm{Hg} \\
\text { Hypotensive effect of all four dipeptides lasted 3-8 weeks after } \\
\text { ceasing continuous administration. }\end{array}$ & [374] \\
\hline${ }^{*}$ ** U. pinnatifida & $\begin{array}{l}\text { (i) Ile-Trp } \\
\text { (ii) Val-Trp } \\
\text { (iii) Ile-Tyr } \\
\text { (iv) Ala-Trp } \\
\text { (v) Leu-Trp } \\
\text { (vi) Val-Tyr } \\
\text { (vii) Phe-Tyr }\end{array}$ & $\begin{array}{l}\text { Enzymatic (Protease from Bacillus } \\
\text { stearothermophilus) and HPLC } \\
\text { separation to butanol-soluble } \\
\text { fractions }\end{array}$ & $\begin{array}{l}\text { (a) vitro ACE-I inhibitory activity } \\
\text { digestion stability study with } \\
\text { pepsin, trypsin and } \\
\text { chymotrypsin. } \\
\text { (b) } \\
\text { In vivo study in spontaneously } \\
\text { hypertensive rats. Single oral } \\
\text { administration of each dipeptide } \\
(1 \mathrm{mg} / \mathrm{kg} \mathrm{BM}) \text {. }\end{array}$ & $\begin{array}{l}\text { (a) No loss in ACE-I inhibitory activity post in vitro } \\
\text { digestion.IC } 50 \text { values: } \\
\text { (i) Ile-Trp } 1.5 \mu \mathrm{M} \\
\text { (ii) Val-Trp } 3.3 \mu \mathrm{M} \\
\text { (iii) Ile-Tyr } 6.1 \mu \mathrm{M} \\
\text { (iv) Ala-Trp } 18.8 \mu \mathrm{M} \\
\text { (v) Leu-Trp } 23.6 \mu \mathrm{M} \\
\text { (vi) Val-Tyr } 35.2 \mu \mathrm{M} \\
\text { (vii) Phe-Tyr } 42.3 \mu \mathrm{M} \\
\text { (b) In vivo antihypertensive effect in spontaneously hypertensive } \\
\text { rats (single oral dose, all } 1 \mathrm{mg} / \mathrm{kg} \text { of BW). Blood pressure } \\
\text { decreases (pre-administration vs. } 9 \mathrm{~h} \text { post) } \\
\text { (i) Val-Tyr }(228.2 \pm 3.4 \text { vs. } 206.7 \pm 9.5 \mathrm{mmHg})(p<0.05) \\
\text { (ii) Ile-Tyr }(205.6 \pm 5.2 \text { vs. } 184.3 \pm 4.5 \mathrm{mmHg})(p<0.05) \\
\text { (iii) Phe-Tyr }(208.7 \pm 4.4 \text { vs. } 193.0 \pm 5.1(p<0.01) \\
\text { (iv) Ile-Trp }(213.3 \pm 3.4 \text { vs. } 199.5 \pm 5.9)(p<0.05) \\
\text { Captopril control }(238.7 \pm 6.9 \text { vs. } 224.9 \pm 4.1(p<0.05)\end{array}$ & [229] \\
\hline
\end{tabular}


Despite the lack of human clinical data on the bioavailability of seaweed peptides, in vivo animal trials and in vitro simulated gastrointestinal digestion studies provide relevant information on the ability of bioactive peptides, sometimes termed cryptides, to retain their efficacy after transit through the mammalian gut $[375,376]$.

\section{Conclusions}

The aetiology of many leading global chronic disorders such as inflammatory disease, immunodeficiency, metabolic syndrome and cancer has been linked to dysbiosis of the gut. In vitro, animal, and human studies collated in this review show that the consumption of seaweed components may have the potential to beneficially modulate the microbiota of the mammalian gut. Seaweed polysaccharides such as fucoidan, laminarin, alginate, ulvan and porphyran have shown particular efficacy as modulators of the gut by acting as prebiotics, which increase gut bacterial numbers and the production of short chain fatty acids. There are, however, many factors that can reduce the bioaccessibility and bioavailability of seaweed components. These include antagonistic or synergistic interactions with other food components; physiochemical digestibility parameters such as solubility, polarity, molecular weight, surrounding food matrix; and the impact of first-pass metabolism. However, the low bioavailability of some seaweed components can be modified by gastric, enterohepatic, and bacterial biotransformation resulting in compounds with enhanced bioactivity. Another factor that affects bioaccessibility and bioavailability is the composition of each individual's gut microbiota, which varies broadly. This may lead to the absence of certain bacterial families required for the metabolism of seaweed components. This can be augmented by introducing bacterial strains capable of digesting them. There is a dearth of data available in the literature on human dietary intervention studies with seaweed polysaccharides, polyphenols and peptides. Although in vitro studies and in vivo animal trials are an indication of the prebiotic potential of seaweed components, they are not fully representative of how the component will be metabolised in humans. Further randomised controlled clinical trials are required in large human cohorts, with measureable endpoints, to validate any putative health effects observed in animal models, simulated digestion models, or in vitro. With the practice of mariculture becoming more widespread globally, seaweeds represent a sustainable source of bioactive compounds with potential to be used as modulators of the gut microbiota.

Author Contributions: Conceptualisation, E.S., M.H. and M.C.; writing-original draft preparation, E.S.; writing - review and editing, E.S., M.H. and M.C.; funding acquisition, E.S. All authors have read and agreed to the published version of the manuscript.

Funding: This research was funded by the Research Leaders 2025 postdoctoral programme, cofunded by Teagasc and the European Union's Horizon 2020 research and innovation programme under the Marie Skłodowska-Curie grant agreement number 754380.

Conflicts of Interest: The authors declare no conflict of interest.

\section{References}

1. Feng, W.; Hu, Y.; An, N.; Feng, Z.; Liu, J.; Mou, J.; Hu, T.; Guan, H.; Zhang, D.; Mao, Y. Alginate oligosaccharide alleviates monocrotaline-induced pulmonary hypertension via anti-oxidant and anti-inflammation pathways in rats. Int. Heart J. 2020, 61, 160-168. [CrossRef] [PubMed]

2. Cotas, J.; Marques, V.; Afonso, M.B.; Rodrigues, C.M.; Pereira, L. Antitumour potential of Gigartina pistillata carrageenans against colorectal cancer stem cell-enriched tumourspheres. Mar. Drugs 2020, 18, 50. [CrossRef] [PubMed]

3. Pacheco, L.V.; Parada, J.; Pérez-Correa, J.R.; Mariotti-Celis, M.S.; Erpel, F.; Zambrano, A.; Palacios, M. Bioactive polyphenols from southern Chile seaweed as inhibitors of enzymes for starch digestion. Mar. Drugs 2020, 18, 353. [CrossRef]

4. Lee, H.-G.; Lu, Y.A.; Li, X.; Hyun, J.-M.; Kim, H.-S.; Lee, J.J; Kim, T.H.; Kim, H.M.; Kang, M.-C. Anti-obesity effects of Grateloupia elliptica, a red seaweed, in mice with high-fat diet-induced obesity via suppression of adipogenic factors in white adipose tissue and increased thermogenic factors in brown adipose tissue. Nutrients 2020, 12, 308. [CrossRef] [PubMed]

5. Pimentel, F.B.; Cermeño, M.; Kleekayai, T.; Harnedy, P.A.; FitzGerald, R.J.; Alves, R.C.; Oliveira, M.B.P. Effect of in vitro simulated gastrointestinal digestion on the antioxidant activity of the red seaweed Porphyra dioica. Food Res. Int. 2020, 136, 109309. [CrossRef] [PubMed] 
6. Irwin, Z.; McSorley, E.M.; Slevin, M.M.; Rowan, L.; McMillen, P.; McCullagh, D.; Magee, P.J.; Gill, C.I.; Cherry, P.; Crowe, W. The effect of a fibre extract from the red seaweed, Palmaria palmata, on lipid metabolism and inflammation in healthy adults. Proc. Nutr. Soc. 2020, 79. [CrossRef]

7. Seca, A.M.; Pinto, D.C. Overview on the antihypertensive and anti-obesity effects of secondary metabolites from seaweeds. Mar. Drugs 2018, 16, 237. [CrossRef]

8. Collins, K.G.; Fitzgerald, G.F.; Stanton, C.; Ross, R.P. Looking beyond the terrestrial: The potential of seaweed derived bioactives to treat non-communicable diseases. Mar. Drugs 2016, 14, 60. [CrossRef]

9. Garcia-Vaquero, M.; Mora, L.; Hayes, M. In vitro and in silico approaches to generating and identifying angiotensin-converting enzyme I inhibitory peptides from green macroalga Ulva lactuca. Mar. Drugs 2019, 17, 204. [CrossRef]

10. Charoensiddhi, S.; Conlon, M.A.; Vuaran, M.S.; Franco, C.M.M.; Zhang, W. Polysaccharide and phlorotannin-enriched extracts of the brown seaweed Ecklonia radiata influence human gut microbiota and fermentation in vitro. J. Appl. Phycol. 2017, 29, 2407-2416. [CrossRef]

11. Dobrinčić, A.; Balbino, S.; Zorić, Z.; Pedisić, S.; Bursać Kovačević, D.; Elez Garofulić, I.; Dragović-Uzelac, V. Advanced technologies for the extraction of marine brown algal polysaccharides. Mar. Drugs 2020, 18, 168. [CrossRef]

12. Hao, T. Research advances on the chemical structures and medicinal values of seaweed polysaccharides. J. Anhui Agric. Sci. 2018, 2018, 14. Available online: http:/ / en.cnki.com.cn/Article_en/CJFDTotal-AHNY201810014.htm (accessed on 11 May 2020).

13. Wijesinghe, W.A.J.P.; Jeon, Y.-J. Biological activities and potential cosmeceutical applications of bioactive components from brown seaweeds: A review. Phytochem. Rev. 2011, 10, 431-443. [CrossRef]

14. Salehi, B.; Sharifi-Rad, J.; Seca, A.M.L.; Pinto, D.C.G.A.; Michalak, I.; Trincone, A.; Mishra, A.P.; Nigam, M.; Zam, W.; Martins, N. Current trends on seaweeds: Looking at chemical composition, phytopharmacology, and cosmetic applications. Molecules 2019, 24, 4182. [CrossRef] [PubMed]

15. Rosa, G.P.; Tavares, W.R.; Sousa, P.M.C.; Pagès, A.K.; Seca, A.M.L.; Pinto, D.C.G.A. Seaweed secondary metabolites with beneficial health effects: An overview of successes in in vivo studies and clinical trials. Mar. Drugs 2019, 18, 8. [CrossRef]

16. Marzullo, P.; Di Renzo, L.; Pugliese, G.; De Siena, M.; Barrea, L.; Muscogiuri, G.; Colao, A.; Savastano, S. From obesity through gut microbiota to cardiovascular diseases: A dangerous journey. Int. J. Obes. Suppl. 2020, 10, 35-49. [CrossRef] [PubMed]

17. Barko, P.C.; McMichael, M.A.; Swanson, K.S.; Williams, D.A. The gastrointestinal microbiome: A Review. J. Vet. Intern. Med. 2018, 32, 9-25. [CrossRef] [PubMed]

18. Milani, C.; Duranti, S.; Bottacini, F.; Casey, E.; Turroni, F.; Mahony, J.; Belzer, C.; Delgado Palacio, S.; Arboleya Montes, S.; Mancabelli, L.; et al. The first microbial colonizers of the human gut: Composition, activities, and health implications of the infant gut microbiota. Microbiol. Mol. Biol. Rev. 2017, 81, e00036-17. [CrossRef] [PubMed]

19. Rinninella, E.; Raoul, P.; Cintoni, M. What is the healthy gut microbiota composition? A changing ecosystem across age, environment, diet, and diseases. Microorganisms 2019, 7, 14. [CrossRef]

20. Flint, H.J. Chapter 6-Variability and stability of the human gut microbiome. In Why Gut Microbes Matter: Understanding Our Microbiome; Flint, H., Ed.; Springer Nature: Cham, Switzerland, 2020; pp. 63-79. [CrossRef]

21. Arumugam, M.; Raes, J.; Pelletier, E.; Le Paslier, D.; Yamada, T.; Mende, D.R.; Fernandes, G.R.; Tap, J.; Bruls, T.; Batto, J.-M.; et al. Enterotypes of the human gut microbiome. Nature 2011, 473, 174-180. [CrossRef] [PubMed]

22. Özgün, C.O.U.; Knut, R.; Dzung, B.D. Modulation of the gut microbiota by prebiotic fibres and bacteriocins. Microb. Ecol. Health Dis. 2017, 28, 1348886. [CrossRef]

23. Busnelli, M.; Manzini, S. The gut microbiota affects host pathophysiology as an endocrine organ: A focus on cardiovascular disease. Nutrients 2020, 12, 79. [CrossRef]

24. Markowiak-Kopeć, P.; Śliżewska, K. The effect of probiotics on the production of short-chain fatty acids by human intestinal microbiome. Nutrients 2020, 12, 1107. [CrossRef] [PubMed]

25. Parada Venegas, D.; De la Fuente, M.K.; Landskron, G.; González, M.J.; Quera, R.; Dijkstra, G.; Harmsen, H.J.; Faber, K.N.; Hermoso, M.A. Short chain fatty acids (SCFAs)-mediated gut epithelial and immune regulation and its relevance for inflammatory bowel diseases. Front. Immunol. 2019, 10, 277. [CrossRef] [PubMed]

26. Silva, Y.P.; Bernardi, A.; Frozza, R.L. The role of short-chain fatty acids from gut microbiota in gut-brain communication. Front. Endocrinol. 2020, 11, 25. [CrossRef] [PubMed]

27. Chambers, E.S.; Preston, T.; Frost, G.; Morrison, D.J. Role of gut microbiota-generated short-chain fatty acids in metabolic and cardiovascular health. Curr. Nutr. Rep. 2018, 7, 198-206. [CrossRef] [PubMed]

28. Carding, S.; Verbeke, K.; Vipond, D.T.; Corfe, B.M.; Owen, L.J. Dysbiosis of the gut microbiota in disease. Microb. Ecol. Health Dis. 2015, 26, 26191. [CrossRef] [PubMed]

29. Ganesan, K.; Chung, S.K.; Vanamala, J.; Xu, B. Causal relationship between diet-induced gut microbiota changes and diabetes: A novel strategy to transplant Faecalibacterium prausnitzii in preventing diabetes. Int. J. Mol. Sci. 2018, 19, 3720. [CrossRef] [PubMed]

30. Levy, M.; Kolodziejczyk, A.A.; Thaiss, C.A.; Elinav, E. Dysbiosis and the immune system. Nat. Rev. Immunol. 2017, 17, 219-232. [CrossRef]

31. Rowin, J.; Xia, Y.; Jung, B.; Sun, J. Gut inflammation and dysbiosis in human motor neuron disease. Physiol. Rep. 2017,5 , e13443. [CrossRef] [PubMed]

32. Zhao, L.; Zhang, F.; Ding, X.; Wu, G.; Lam, Y.Y.; Wang, X.; Fu, H.; Xue, X.; Lu, C.; Ma, J.; et al. Gut bacteria selectively promoted by dietary fibers alleviate type 2 diabetes. Science 2018, 359, 1151-1156. [CrossRef] [PubMed] 
33. Charoensiddhi, S.; Abraham, R.E.; Su, P.; Zhang, W. Chapter Four-Seaweed and seaweed-derived metabolites as prebiotics. In Advances in Food and Nutrition Research; Toldrá, F., Ed.; Academic Press: Cambridge, MA, USA, 2020; Volume 91, pp. 97-156. [CrossRef]

34. Hu, B.; Gong, Q.; Wang, Y.; Ma, Y.; Li, J.; Yu, W. Prebiotic effects of neoagaro-oligosaccharides prepared by enzymatic hydrolysis of agarose. Anaerobe 2006, 12, 260-266. [CrossRef] [PubMed]

35. Alam, M.A.; Parra-Saldivar, R.; Bilal, M.; Afroze, C.A.; Ahmed, M.N.; Iqbal, H.M.N.; Xu, J. Algae-derived bioactive molecules for the potential treatment of SARS-CoV-2. Molecules 2021, 26, 2134. [CrossRef]

36. Ajanth Praveen, M.; Karthika Parvathy, K.R.; Jayabalan, R.; Balasubramanian, P. Dietary fiber from Indian edible seaweeds and its in-vitro prebiotic effect on the gut microbiota. Food Hydrocoll. 2019, 96, 343-353. [CrossRef]

37. Kawabata, K.; Yoshioka, Y.; Terao, J. Role of intestinal microbiota in the bioavailability and physiological functions of dietary polyphenols. Molecules 2019, 24, 370. [CrossRef]

38. Quigley, E.M.M. Prebiotics and probiotics in digestive health. Clin. Gastroenterol. Hepatol. 2019, 17, 333-344. [CrossRef]

39. Coelho, M.C.; Ribeiro, T.B.; Oliveira, C.; Batista, P.; Castro, P.; Monforte, A.R.; Rodrigues, A.S.; Teixeira, J.; Pintado, M. In vitro gastrointestinal digestion impact on the bioaccessibility and antioxidant capacity of bioactive compounds from tomato flours obtained after conventional and ohmic heating extraction. Foods 2021, 10, 554. [CrossRef]

40. Neal, M.J. Chap 3-Drug absorption, distribution and excretion In Medical Pharmacology at a Glance, 9th ed.; Neal, M.J., Ed.; John Wiley \& Sons: Oxford, UK, 2020. Available online: https:/ / www.wiley.com/en-au/Medical+Pharmacology+at+a+Glance\%2C+9th+ Edition-p-9781119548096 (accessed on 15 May 2020).

41. Srinivasan, V.S. Bioavailability of nutrients: A practical approach to in vitro demonstration of the availability of nutrients in multivitamin-mineral combination products. J. Nutr. 2001, 131, 1349S-1350S. [CrossRef]

42. Fernández-García, E.; Carvajal-Lérida, I.; Pérez-Gálvez, A. In vitro bioaccessibility assessment as a prediction tool of nutritional efficiency. Nutr. Res. 2009, 29, 751-760. [CrossRef]

43. Santos, D.I.; Saraiva, J.M.A.; Vicente, A.A.; Moldão-Martins, M. Chapter 2-Methods for determining bioavailability and bioaccessibility of bioactive compounds and nutrients. In Innovative Thermal and Non-Thermal Processing, Bioaccessibility and Bioavailability of Nutrients and Bioactive Compounds; Barba, F.J., Saraiva, J.M.A., Cravotto, G., Lorenzo, J.M., Eds.; Woodhead Publishing: Cambridge, UK, 2019; pp. 23-54. [CrossRef]

44. Pozharitskaya, O.N.; Shikov, A.N.; Faustova, N.M.; Obluchinskaya, E.D.; Kosman, V.M.; Vuorela, H.; Makarov, V.G. Pharmacokinetic and tissue distribution of fucoidan from Fucus vesiculosus after oral administration to rats. Mar. Drugs 2018, 16, 132. [CrossRef] [PubMed]

45. Nishikawa, T.; Yokose, T.; Yamamoto, Y.; Yamaguchi, K.; Oda, T. Detection and pharmacokinetics of alginate oligosaccharides in mouse plasma and urine after oral administration by a liquid chromatography/tandem mass spectrometry (LC-MS/MS) method. Biosci. Biotechnol. Biochem. 2008, 72, 2184-2190. [CrossRef]

46. Ventura, S.; Rodrigues, M.; Falcão, A.; Alves, G. Safety evidence on the administration of Fucus vesiculosus L. (bladderwrack) extract and lamotrigine: Data from pharmacokinetic studies in the rat. Drug Chem. Toxicol. 2020, 43, 560-566. [CrossRef]

47. Zhang, E.; Chu, F.; Zhao, T.; Chai, Y.; Liang, H.; Song, S.; Ji, A. Determination of fucoidan in rat plasma by HPLC and its application in pharmacokinetics. Pak. J. Pharm. Sci. 2020, 33. [CrossRef]

48. Lu, J.; Pan, Q.; Zhou, J.; Weng, Y.; Chen, K.; Shi, L.; Zhu, G.; Chen, C.; Li, L.; Geng, M.; et al. Pharmacokinetics, distribution, and excretion of sodium oligomannate, a recently approved anti-Alzheimer's disease drug in China. J. Pharm. Anal. 2021. [CrossRef]

49. Pozharitskaya, O.N.; Shikov, A.N.; Obluchinskaya, E.D.; Vuorela, H. The pharmacokinetics of fucoidan after topical application to rats. Mar. Drugs 2019, 17, 687. [CrossRef]

50. Corino, C.; Di Giancamillo, A.; Modina, S.C.; Rossi, R. Prebiotic effects of seaweed polysaccharides in pigs. Animals 2021, 11, 1573. [CrossRef] [PubMed]

51. Shikov, A.N.; Flisyuk, E.V.; Obluchinskaya, E.D.; Pozharitskaya, O.N. Pharmacokinetics of marine-derived drugs. Mar. Drugs 2020, 18, 557. [CrossRef]

52. Mohammed, A.S.A.; Naveed, M.; Jost, N. Polysaccharides; classification, chemical properties, and future perspective applications in fields of pharmacology and biological medicine (A review of current applications and upcoming potentialities). J. Polym. Environ. 2021. [CrossRef]

53. Rasmussen, R.S.; Morrissey, M.T. Marine Biotechnology for Production of Food Ingredients. In Advances in Food and Nutrition Research; Academic Press: Cambridge, MA, USA, 2007; Volume 52, pp. 237-292. [CrossRef]

54. Peñalver, R.; Lorenzo, J.M.; Ros, G.; Amarowicz, R.; Pateiro, M.; Nieto, G. Seaweeds as a functional ingredient for a healthy diet. Mar. Drugs 2020, 18, 301. [CrossRef] [PubMed]

55. Wong, K.H.; Cheung, P.C.K. Nutritional evaluation of some subtropical red and green seaweeds: Part I—Proximate composition, amino acid profiles and some physico-chemical properties. Food Chem. 2000, 71, 475-482. [CrossRef]

56. Cherry, P.; O’Hara, C.; Magee, P.J.; McSorley, E.M.; Allsopp, P.J. Risks and benefits of consuming edible seaweeds. Nutr. Rev. 2019, 77, 307-329. [CrossRef]

57. Kraan, S. Chapter 22-Algal polysaccharides, novel applications and outlook. In Carbohydrates-Comprehensive Studies on Glycobiology and Glycotechnology; Chang, C.F., Ed.; IntechOpen: Rijeka, Croatia, 2012. [CrossRef]

58. de Jesus Raposo, M.F.; de Morais, A.M.; de Morais, R.M. Emergent sources of prebiotics: Seaweeds and microalgae. Mar. Drugs 2016, 14, 27. [CrossRef] 
59. Sanz-Pintos, N.; Pérez-Jiménez, J.; Buschmann, A.H.; Vergara-Salinas, J.R.; Pérez-Correa, J.R.; Saura-Calixto, F. Macromolecular antioxidants and dietary fiber in edible seaweeds. J. Food Sci. 2017, 82, 289-295. [CrossRef]

60. Fernando, I.P.S.; Kim, K.-N.; Kim, D.; Jeon, Y.-J. Algal polysaccharides: Potential bioactive substances for cosmeceutical applications. Crit. Rev. Biotechnol. 2019, 39, 99-113. [CrossRef]

61. Olsson, J.; Toth, G.B.; Albers, E. Biochemical composition of red, green and brown seaweeds on the Swedish west coast. J. Appl. Phycol. 2020. [CrossRef]

62. Tannock, G.W.; Liu, Y. Guided dietary fibre intake as a means of directing short-chain fatty acid production by the gut microbiota. J. R. Soc. N. Z. 2020, 50, 434-455. [CrossRef]

63. Hjorth, M.F.; Astrup, A. The role of viscous fiber for weight loss: Food for thought and gut bacteria. Am. J. Clin. Nutr. 2020. [CrossRef] [PubMed]

64. Bindels, L.B.; Delzenne, N.M.; Cani, P.D.; Walter, J. Towards a more comprehensive concept for prebiotics. Nat. Rev. Gastroenterol. Hepatol. 2015, 12, 303-310. [CrossRef] [PubMed]

65. Li, M.; Shang, Q.; Li, G.; Wang, X.; Yu, G. Degradation of marine algae-derived carbohydrates by Bacteroidetes isolated from human gut microbiota. Mar. Drugs 2017, 15, 92. [CrossRef] [PubMed]

66. Tamura, K.; Hemsworth, G.R.; Déjean, G.; Rogers, T.E.; Pudlo, N.A.; Urs, K.; Jain, N.; Davies, G.J.; Martens, E.C.; Brumer, H. Molecular mechanism by which prominent human gut bacteroidetes utilize mixed-linkage beta-glucans, major health-promoting cereal polysaccharides. Cell Rep. 2017, 21, 417-430. [CrossRef] [PubMed]

67. Salyers, A.A.; Vercellotti, J.R.; West, S.E.; Wilkins, T.D. Fermentation of mucin and plant polysaccharides by strains of Bacteroides from the human colon. Appl. Environ. Microbiol. 1977, 33, 319-322. Available online: https://aem.asm.org/content/33/2/319 .short (accessed on 11 August 2020). [CrossRef] [PubMed]

68. Becker, S.; Tebben, J.; Coffinet, S.; Wiltshire, K.; Iversen, M.H.; Harder, T.; Hinrichs, K.-U.; Hehemann, J.-H. Laminarin is a major molecule in the marine carbon cycle. Proc. Natl. Acad. Sci. USA 2020, 117, 6599-6607. [CrossRef] [PubMed]

69. Zaharudin, N.; Tullin, M.; Pekmez, C.T.; Sloth, J.J.; Rasmussen, R.R.; Dragsted, L.O. Effects of brown seaweeds on postprandial glucose, insulin and appetite in humans-A randomized, 3-way, blinded, cross-over meal study. Clin. Nutr. 2020. [CrossRef] [PubMed]

70. Hui, Y.; Tamez-Hidalgo, P.; Cieplak, T.; Satessa, G.D.; Kot, W.; Søren, S.K.; Nielsen, M.O.; Nielsen, D.S.; Krych, L. Supplementation of a lacto-fermented rapeseed-seaweed blend promotes gut microbial- and gut immune-modulation in weaner piglets. bioRxiv 2020, 2020.09.22.308106. [CrossRef]

71. Chen, L.; Xu, W.; Chen, D.; Chen, G.; Liu, J.; Zeng, X.; Shao, R.; Zhu, H. Digestibility of sulfated polysaccharide from the brown seaweed Ascophyllum nodosum and its effect on the human gut microbiota in vitro. Int. J. Biol. Macromol. 2018, 112, $1055-1061$. [CrossRef] [PubMed]

72. You, L.; Gong, Y.; Li, L.; Hu, X.; Brennan, C.; Kulikouskaya, V. Beneficial effects of three brown seaweed polysaccharides on gut microbiota and their structural characteristics: An overview. Int. J. Food Sci. Tech. 2020, 55, 1199-1206. [CrossRef]

73. de Borba Gurpilhares, D.; Cinelli, L.P.; Simas, N.K.; Pessoa, A., Jr.; Sette, L.D. Marine prebiotics: Polysaccharides and oligosaccharides obtained by using microbial enzymes. Food Chem. 2019, 280, 175-186. [CrossRef] [PubMed]

74. Garcia-Vaquero, M.; Rajauria, G.; O’Doherty, J.V.; Sweeney, T. Polysaccharides from macroalgae: Recent advances, innovative technologies and challenges in extraction and purification. Food Res. Int. 2017, 99, 1011-1020. [CrossRef] [PubMed]

75. Usov, A.; Zelinsky, N. Chapter 2-Chemical structures of algal polysaccharides. In Functional Ingredients from Algae for Foods and Nutraceuticals; Domínguez, H., Ed.; Woodhead Publishing: Cambridge, UK, 2013; pp. 23-86. [CrossRef]

76. Tanna, B.; Mishra, A. Nutraceutical potential of seaweed polysaccharides: Structure, bioactivity, safety, and toxicity. Compr. Rev. Food Sci. Food Saf. 2019, 18, 817-831. [CrossRef]

77. Koh, H.S.A.; Lu, J.; Zhou, W. Structure characterization and antioxidant activity of fucoidan isolated from Undaria pinnatifida grown in New Zealand. Carbohydr. Polym. 2019, 212, 178-185. [CrossRef]

78. Deniaud-Bouët, E.; Hardouin, K.; Potin, P.; Kloareg, B.; Hervé, C. A review about brown algal cell walls and fucose-containing sulfated polysaccharides: Cell wall context, biomedical properties and key research challenges. Carbohydr. Polym. 2017, 175, 395-408. [CrossRef] [PubMed]

79. Skriptsova, A.V. Fucoidans of brown algae: Biosynthesis, localization, and physiological role in thallus. Russ. J. Mar. Biol. 2015, 41, 145-156. [CrossRef]

80. Usoltseva, R.V.; Anastyuk, S.D.; Surits, V.V.; Shevchenko, N.M.; Thinh, P.D.; Zadorozhny, P.A.; Ermakova, S.P. Comparison of structure and in vitro anticancer activity of native and modified fucoidans from Sargassum feldmannii and S. duplicatum. Int. J. Biol. Macromol. 2019, 124, 220-228. [CrossRef] [PubMed]

81. Elizondo-Gonzalez, R.; Cruz-Suarez, L.E.; Ricque-Marie, D.; Mendoza-Gamboa, E.; Rodriguez-Padilla, C.; Trejo-Avila, L.M. In vitro characterization of the antiviral activity of fucoidan from Cladosiphon okamuranus against Newcastle Disease Virus. Virol. J. 2012, 9, 307. [CrossRef] [PubMed]

82. Hwang, P.A.; Phan, N.N.; Lu, W.J.; Ngoc Hieu, B.T.; Lin, Y.C. Low-molecular-weight fucoidan and high-stability fucoxanthin from brown seaweed exert prebiotics and anti-inflammatory activities in Caco-2 cells. Food Nutr. Res. 2016, 60. [CrossRef]

83. Irhimeh, M.R.; Fitton, J.H.; Lowenthal, R.M. Pilot clinical study to evaluate the anticoagulant activity of fucoidan. Blood Coagul. Fibrinolysis 2009, 20, 607-610. [CrossRef] 
84. Tsai, H.-L.; Tai, C.-J.; Huang, C.-W.; Chang, F.-R.; Wang, J.-Y. Efficacy of low-molecular-weight fucoidan as a supplemental therapy in metastatic colorectal cancer patients: A double-blind randomized controlled trial. Mar. Drugs 2017, 15, 122. [CrossRef]

85. Maruyama, H.; Tamauchi, H.; Hashimoto, M.; Nakano, T. Antitumor activity and immune response of Mekabu fucoidan extracted from sporophyll of Undaria pinnatifida. In Vivo 2003, 17, 245-249. Available online: http:/ / europepmc.org/abstract/MED/129295 74 (accessed on 19 May 2020).

86. Lin, H.-T.V.; Tsou, Y.-C.; Chen, Y.-T.; Lu, W.-J.; Hwang, P.-A. Effects of low-molecular-weight fucoidan and high stability fucoxanthin on glucose homeostasis, lipid metabolism, and liver function in a mouse model of type II diabetes. Mar. Drugs 2017, 15, 113. [CrossRef]

87. Okolie, C.L.; Mason, B.; Mohan, A.; Pitts, N.; Udenigwe, C.C. The comparative influence of novel extraction technologies on in vitro prebiotic-inducing chemical properties of fucoidan extracts from Ascophyllum nodosum. Food Hydrocoll. 2019, 90, 462-471. [CrossRef]

88. Kan, J.; Cheng, J.; Xu, L.; Hood, M.; Zhong, D.; Cheng, M.; Liu, Y.; Chen, L.; Du, J. The combination of wheat peptides and fucoidan protects against chronic superficial gastritis and alters gut microbiota: A double-blinded, placebo-controlled study. Eur. J. Nutr. 2020, 59, 1655-1666. [CrossRef] [PubMed]

89. Takahashi, M.; Takahashi, K.; Abe, S.; Yamada, K.; Suzuki, M.; Masahisa, M.; Endo, M.; Abe, K.; Inoue, R.; Hoshi, H. Improvement of psoriasis by alteration of the gut environment by oral administration of fucoidan from Cladosiphon okamuranus. Mar. Drugs 2020, 18, 154. [CrossRef]

90. Parnell, J.A.; Reimer, R.A. Prebiotic fiber modulation of the gut microbiota improves risk factors for obesity and the metabolic syndrome. Gut Microbes 2012, 3, 29-34. [CrossRef]

91. Zhang, X.; Liu, Y.; Chen, X.-Q.; Aweya, J.J.; Cheong, K.-L. Catabolism of Saccharina japonica polysaccharides and oligosaccharides by human fecal microbiota. LWT 2020, 130, 109635. [CrossRef]

92. Shang, Q.; Shan, X.; Cai, C.; Hao, J.; Li, G.; Yu, G. Dietary fucoidan modulates the gut microbiota in mice by increasing the abundance of Lactobacillus and Ruminococcaceae. Food Funct. 2016, 7, 3224-3232. [CrossRef]

93. Olatunji, O. Aquatic Biopolymers: Understanding Their Industrial Significance and Environmental Implications; Springer Nature: Cham, Switzerland, 2020.

94. Baweja, P.; Sahoo, D. Chapter 2-Classification of algae. In The Algae World; Sahoo, D., Seckbach, J., Eds.; Springer: Dordrecht, The Netherlands, 2015; pp. 31-55. [CrossRef]

95. Usman, A.; Khalid, S.; Usman, A.; Hussain, Z.; Wang, Y. Chapter 5-Algal polysaccharides, novel application, and outlook. In Algae Based Polymers, Blends, and Composites; Zia, K.M., Zuber, M., Ali, M., Eds.; Elsevier: Amsterdam, The Netherlands, 2017; pp. 115-153. [CrossRef]

96. Kadam, S.U.; O’Donnell, C.P.; Rai, D.K.; Hossain, M.B.; Burgess, C.M.; Walsh, D.; Tiwari, B.K. Laminarin from Irish brown seaweeds Ascophyllum nodosum and Laminaria hyperborea: Ultrasound assisted extraction, characterization and bioactivity. Mar. Drugs 2015, 13, 4270-4280. [CrossRef] [PubMed]

97. Song, K.; Xu, L.; Zhang, W.; Cai, Y.; Jang, B.; Oh, J.; Jin, J.O. Laminarin promotes anti-cancer immunity by the maturation of dendritic cells. Oncotarget 2017, 8, 38554-38567. [CrossRef] [PubMed]

98. Miao, H.-Q.; Elkin, M.; Aingorn, E.; Ishai-Michaeli, R.; Stein, C.A.; Vlodavsky, I. Inhibition of heparanase activity and tumor metastasis by laminarin sulfate and synthetic phosphorothioate oligodeoxynucleotides. Int. J. Cancer 1999, 83, 424-431. [CrossRef]

99. Cuong, D.X. Laminarin (beta-glucan) of brown algae Sargassum mcclurei: Extraction, antioxidant activity, lipoxygenase inhibition activity, and physicochemistry properties. World J. Food Sci. Technol. 2020, 4, 31. [CrossRef]

100. Lee, J.; Kim, Y.-J.; Kim, H.; Kim, Y.-S.; Park, W. Immunostimulatory effect of laminarin on RAW 264.7 mouse macrophages. Molecules 2012, 17, 5404-5411. [CrossRef]

101. Leonard, S.; Sweeney, T.; Bahar, B.; O’Doherty, J. Effect of maternal seaweed extract supplementation on suckling piglet growth, humoral immunity, selected microflora, and immune response after an ex vivo lipopolysaccharide challenge. J. Anim. Sci. 2012, 90, 505-514. [CrossRef]

102. Vigors, S.; O’Doherty, J.V.; Rattigan, R.; McDonnell, M.J.; Rajauria, G.; Sweeney, T. Effect of a laminarin rich macroalgal extract on the caecal and colonic microbiota in the post-weaned pig. Mar. Drugs 2020, 18, 157. [CrossRef] [PubMed]

103. Rattigan, R.; Sweeney, T.; Maher, S.; Thornton, K.; Rajauria, G.; O’Doherty, J.V. Laminarin-rich extract improves growth performance, small intestinal morphology, gene expression of nutrient transporters and the large intestinal microbial composition of piglets during the critical post-weaning period. Br. J. Nutr. 2019, 123, 255-263. [CrossRef] [PubMed]

104. Lynch, M.B.; Sweeney, T.; Callan, J.J.; O'Sullivan, J.T.; O'Doherty, J.V. The effect of dietary Laminaria-derived laminarin and fucoidan on nutrient digestibility, nitrogen utilisation, intestinal microflora and volatile fatty acid concentration in pigs. J. Sci. Food Agric. 2010, 90, 430-437. [CrossRef] [PubMed]

105. Zhang, Y.; Zhao, N.; Yang, L.; Hong, Z.; Cai, B.; Le, Q.; Yang, T.; Shi, L.; He, J.; Cui, C.-B. Insoluble dietary fiber derived from brown seaweed Laminaria japonica ameliorate obesity-related features via modulating gut microbiota dysbiosis in high-fat diet-fed mice. Food Funct. 2020. [CrossRef]

106. O'Sullivan, L.; Murphy, B.; McLoughlin, P.; Duggan, P.; Lawlor, P.G.; Hughes, H.; Gardiner, G.E. Prebiotics from marine macroalgae for human and animal health applications. Mar. Drugs 2010, 8, 2038-2064. [CrossRef]

107. Pereira, L.; Cotas, J. Chapter 1-Introductory chapter: Alginates-a general overview. In Alginates-Recent Uses of This Natural Polymer; Pereira, L., Ed.; IntechOpen: Rijeka, Croatia, 2020. [CrossRef] 
108. Mei, X.; Chang, Y.; Shen, J.; Zhang, Y.; Xue, C. Expression and characterization of a novel alginate-binding protein: A promising tool for investigating alginate. Carbohydr. Polym. 2020, 246, 116645. [CrossRef]

109. Ramos, P.E.; Silva, P.; Alario, M.M.; Pastrana, L.M.; Teixeira, J.A.; Cerqueira, M.A.; Vicente, A.A. Effect of alginate molecular weight and $M / G$ ratio in beads properties foreseeing the protection of probiotics. Food Hydrocoll. 2018, 77, 8-16. [CrossRef]

110. Mancini, F.; Montanari, L.; Peressini, D.; Fantozzi, P. Influence of alginate concentration and molecular weight on functional properties of mayonnaise. LWT 2002, 35, 517-525. [CrossRef]

111. Jönsson, M.; Allahgholi, L.; Sardari, R.R.; Hreggviðsson, G.O.; Nordberg Karlsson, E. Extraction and modification of macroalgal polysaccharides for current and next-generation applications. Molecules 2020, 25, 930. [CrossRef]

112. Bai, S.; Chen, H.; Zhu, L.; Liu, W.; Yu, H.D.; Wang, X.; Yin, Y. Comparative study on the in vitro effects of Pseudomonas aeruginosa and seaweed alginates on human gut microbiota. PLoS ONE 2017, 12, e0171576. [CrossRef] [PubMed]

113. Li, M.; Li, G.; Shang, Q.; Chen, X.; Liu, W.; Pi, X.; Zhu, L.; Yin, Y.; Yu, G.; Wang, X. In vitro fermentation of alginate and its derivatives by human gut microbiota. Anaerobe 2016, 39, 19-25. [CrossRef] [PubMed]

114. Mizuno, H.; Bamba, S.; Abe, N.; Sasaki, M. Effects of an alginate-containing variable-viscosity enteral nutrition formula on defecation, intestinal microbiota, and short-chain fatty acid production. J. Funct. Foods 2020, 67, 103852. [CrossRef]

115. Georg-Jensen, M.; Pedersen, C.; Kristensen, M.; Frost, G.; Astrup, A. Efficacy of alginate supplementation in relation to appetite regulation and metabolic risk factors: Evidence from animal and human studies. Obes. Rev. 2013, 14, 129-144. [CrossRef] [PubMed]

116. Guo, L.; Goff, H.D.; Xu, F.; Liu, F.; Ma, J.; Chen, M.; Zhong, F. The effect of sodium alginate on nutrient digestion and metabolic responses during both in vitro and in vivo digestion process. Food Hydrocoll. 2020, 107, 105304. [CrossRef]

117. Hu, Y.; Feng, Z.; Feng, W.; Hu, T.; Guan, H.; Mao, Y. AOS ameliorates monocrotaline-induced pulmonary hypertension by restraining the activation of P-selectin/p38MAPK/NF-kB pathway in rats. Biomed. Pharmacother. 2019, 109, 1319-1326. [CrossRef]

118. Amimi, A.; Mouradi, A.; Bennasser, L.; Givernaud, T. Seasonal variations in thalli and carrageenan composition of Gigartina pistillata (Gmelin) Stackhouse (Rhodophyta, Gigartinales) harvested along the Atlantic coast of Morocco. Phycol. Res. 2007, 55, 143-149. [CrossRef]

119. Jiao, G.; Yu, G.; Zhang, J.; Ewart, H.S. Chemical structures and bioactivities of sulfated polysaccharides from marine algae. Mar. Drugs 2011, 9, 196-223. [CrossRef]

120. Oladzadabbasabadi, N.; Ebadi, S.; Nafchi, A.M.; Karim, A.; Kiahosseini, S.R. Functional properties of dually modified sago starch/K-carrageenan films: An alternative to gelatin in pharmaceutical capsules. Carbohydr. Polym. 2017, 160, 43-51. [CrossRef]

121. McKim, J.; Willoughby, J.; Blakemore, W.; Weiner, M. Clarifying the confusion between poligeenan, degraded carrageenan, and carrageenan: A review of the chemistry, nomenclature, and in vivo toxicology by the oral route. Crit. Rev. Food Sci. Nutr. 2018, 59, 1-70. [CrossRef]

122. Uno, Y.; Omoto, T.; Goto, Y.; Asai, I.; Nakamura, M.; Maitani, T. Molecular weight distribution of carrageenans studied by a combined gel permeation/inductively coupled plasma (GPC/ICP) method. Food Addit. Contam. 2001, 18, 763-772. [CrossRef]

123. Du Preez, R.; Paul, N.; Mouatt, P.; Majzoub, M.E.; Thomas, T.; Panchal, S.K.; Brown, L. Carrageenans from the red seaweed Sarconema filiforme attenuate symptoms of diet-induced metabolic syndrome in rats. Mar. Drugs 2020, 18, 97. [CrossRef] [PubMed]

124. Sun, Y.; Cui, X.; Duan, M.; Ai, C.; Song, S.; Chen, X. In vitro fermentation of K-carrageenan oligosaccharides by human gut microbiota and its inflammatory effect on HT29 cells. J. Func. Foods 2019, 59, 80-91. [CrossRef]

125. Isaka, S.; Cho, K.; Nakazono, S.; Abu, R.; Ueno, M.; Kim, D.; Oda, T. Antioxidant and anti-inflammatory activities of porphyran isolated from discolored nori (Porphyra yezoensis). Int. J. Biol. Macromol. 2015, 74, 68-75. [CrossRef]

126. Xu, S.-Y.; Aweya, J.J.; Li, N.; Deng, R.-Y.; Chen, W.-Y.; Tang, J.; Cheong, K.-L. Microbial catabolism of Porphyra haitanensis polysaccharides by human gut microbiota. Food Chem. 2019, 289, 177-186. [CrossRef] [PubMed]

127. Qiu, H.-M.; Veeraperumal, S.; Lv, J.-H.; Wu, T.-C.; Zhang, Z.-P.; Zeng, Q.-K.; Liu, Y.; Chen, X.-Q.; Aweya, J.J.; Cheong, K.-L. Physicochemical properties and potential beneficial effects of porphyran from Porphyra haitanensis on intestinal epithelial cells. Carbohydr. Polym. 2020, 246, 116626. [CrossRef] [PubMed]

128. Zhao, T.; Zhang, Q.; Qi, H.; Zhang, H.; Niu, X.; Xu, Z.; Li, Z. Degradation of porphyran from Porphyra haitanensis and the antioxidant activities of the degraded porphyrans with different molecular weight. Int. J. Biol. Macromol. 2006, 38, 45-50. [CrossRef]

129. Bhatia, S.; Sharma, A.; Sharma, K.; Kavale, M.; Chaugule, B.; Dhalwal, K.; Namdeo, A.; Mahadik, K. Novel algal polysaccharides from marine source: Porphyran. Pharmacogn. Rev. 2008, 2, 271. Available online: https://www.phcogrev.com/sites/default/ files/PhcogRev-2-4-271.pdf (accessed on 8 June 2020).

130. He, D.; Wu, S.; Yan, L.; Zuo, J.; Cheng, Y.; Wang, H.; Liu, J.; Zhang, X.; Wu, M.; Choi, J.-I.; et al. Antitumor bioactivity of porphyran extracted from Pyropia yezoensis Chonsoo2 on human cancer cell lines. J. Sci. Food Agric. 2019, 99, 6722-6730. [CrossRef]

131. Kwon, M.-J.; Nam, T.-J. Chromatographically purified porphyran from Porphyra yezoensis effectively inhibits proliferation of human cancer cells. Food Sci. Biotechnol. 2007, 16, 873-878. Available online: https://www.koreascience.or.kr/article/JAKO20070 9905796598.page (accessed on 13 July 2020).

132. Seong, H.; Bae, J.-H.; Seo, J.S.; Kim, S.-A.; Kim, T.-J.; Han, N.S. Comparative analysis of prebiotic effects of seaweed polysaccharides laminaran, porphyran, and ulvan using in vitro human fecal fermentation. J. Funct. Foods 2019, 57, 408-416. [CrossRef]

133. Xu, S.-Y.; Chen, X.-Q.; Liu, Y.; Cheong, K.-L. Ultrasonic/microwave-assisted extraction, simulated digestion, and fermentation in vitro by human intestinal flora of polysaccharides from Porphyra haitanensis. Int. J. Biol. Macromol. 2020, 152, 748-756. [CrossRef] 
134. Kulshreshtha, G.; Rathgeber, B.; Stratton, G.; Thomas, N.; Evans, F.; Critchley, A.; Hafting, J.; Prithiviraj, B. Feed supplementation with red seaweeds, Chondrus crispus and Sarcodiotheca gaudichaudii, affects performance, egg quality, and gut microbiota of layer hens. Poult. Sci. 2014, 93, 2991-3001. [CrossRef]

135. Liu, J.; Kandasamy, S.; Zhang, J.; Kirby, C.W.; Karakach, T.; Hafting, J.; Critchley, A.T.; Evans, F.; Prithiviraj, B. Prebiotic effects of diet supplemented with the cultivated red seaweed Chondrus crispus or with fructo-oligo-saccharide on host immunity, colonic microbiota and gut microbial metabolites. BMC Complement. Altern. Med. 2015, 15, 279. [CrossRef]

136. Balasubramanian, B.; Shanmugam, S.; Park, S.; Recharla, N.; Koo, J.S.; Andretta, I.; Kim, I.H. Supplemental impact of marine red seaweed (Halymenia palmata) on the growth performance, total tract nutrient digestibility, blood profiles, intestine histomorphology, meat quality, fecal gas emission, and microbial counts in broilers. Animals 2021, 11, 1244. [CrossRef]

137. Lahaye, M. NMR spectroscopic characterisation of oligosaccharides from two Ulva rigida ulvan samples (Ulvales, Chlorophyta) degraded by a lyase. Carbohydr. Res. 1998, 314, 1-12. [CrossRef]

138. Michel, G.; Czjzek, M. Chapter 16-Polysaccharide-degrading enzymes from marine bacteria. In Marine Enzymes for Biocatalysis: Sources, Biocatalytic Characteristics and Bioprocesses of Marine Enzymes; Trincone, A., Ed.; Woodhead Publishing: Cambridge, UK, 2013; pp. 429-464. [CrossRef]

139. Kidgell, J.T.; Magnusson, M.; de Nys, R.; Glasson, C.R.K. Ulvan: A systematic review of extraction, composition and function. Algal Res. 2019, 39, 101422. [CrossRef]

140. Adrien, A.; Bonnet, A.; Dufour, D.; Baudouin, S.; Maugard, T.; Bridiau, N. Anticoagulant activity of sulfated ulvan isolated from the green macroalga Ulva rigida. Mar. Drugs 2019, 17, 291. [CrossRef] [PubMed]

141. Klongklaew, N.; Praiboon, J.; Tamtin, M.; Srisapoome, P. Antibacterial and antiviral activities of local Thai green macroalgae crude extracts in pacific white shrimp (Litopenaeus vannamei). Mar. Drugs 2020, 18, 140. [CrossRef] [PubMed]

142. Chi, Y.; Zhang, M.; Wang, X.; Fu, X.; Guan, H.; Wang, P. Ulvan lyase assisted structural characterization of ulvan from Ulva pertusa and its antiviral activity against vesicular stomatitis virus. Int. J. Biol. Macromol. 2020, 157, 75-82. [CrossRef] [PubMed]

143. Berri, M.; Olivier, M.; Holbert, S.; Dupont, J.; Demais, H.; Le Goff, M.; Collen, P.N. Ulvan from Ulva armoricana (Chlorophyta) activates the PI3K/Akt signalling pathway via TLR4 to induce intestinal cytokine production. Algal Res. 2017, $28,39-47$. [CrossRef]

144. Cañedo-Castro, B.; Piñón-Gimate, A.; Carrillo, S.; Ramos, D.; Casas-Valdez, M. Prebiotic effect of Ulva rigida meal on the intestinal integrity and serum cholesterol and triglyceride content in broilers. J. Appl. Phycol. 2019, 31, 3265-3273. [CrossRef]

145. Shalaby, M.; Amin, H. Potential using of ulvan polysaccharides from Ulva lactuca as a prebiotic in symbiotic yogurt production. J. Probiot. Health 2019, 7, 1-9. [CrossRef]

146. Kong, Q.; Dong, S.; Gao, J.; Jiang, C. In vitro fermentation of sulfated polysaccharides from E. prolifera and L. japonica by human fecal microbiota. Int. J. Biol. Macromol. 2016, 91, 867-871. [CrossRef]

147. Strain, C.R.; Collins, K.C.; Naughton, V.; McSorley, E.M.; Stanton, C.; Smyth, T.J.; Soler-Vila, A.; Rea, M.C.; Ross, P.R.; Cherry, P.; et al. Effects of a polysaccharide-rich extract derived from Irish-sourced Laminaria digitata on the composition and metabolic activity of the human gut microbiota using an in vitro colonic model. Eur. J. Nutr. 2020, 59, 309-325. [CrossRef] [PubMed]

148. Charoensiddhi, S.; Conlon, M.A.; Vuaran, M.S.; Franco, C.M.M.; Zhang, W. Impact of extraction processes on prebiotic potential of the brown seaweed Ecklonia radiata by in vitro human gut bacteria fermentation. J. Funct. Foods 2016, 24, 221-230. [CrossRef]

149. Charoensiddhi, S.; Conlon, M.A.; Methacanon, P.; Franco, C.M.M.; Su, P.; Zhang, W. Gut health benefits of brown seaweed Ecklonia radiata and its polysaccharides demonstrated in vivo in a rat model. J. Funct. Foods 2017, 37, 676-684. [CrossRef]

150. Wang, Y.; Chen, G.; Peng, Y.; Rui, Y.; Zeng, X.; Ye, H. Simulated digestion and fermentation in vitro with human gut microbiota of polysaccharides from Coralline pilulifera. LWT 2019, 100, 167-174. [CrossRef]

151. Cui, M.; Zhou, R.; Wang, Y.; Zhang, M.; Liu, K.; Ma, C. Beneficial effects of sulfated polysaccharides from the red seaweed Gelidium pacificum Okamura on mice with antibiotic-associated diarrhea. Food Funct. 2020, 11, 4625-4637. [CrossRef] [PubMed]

152. Sun, L.; Warren, F.J.; Gidley, M.J. Natural products for glycaemic control: Polyphenols as inhibitors of alpha-amylase. Trends Food Sci. Technol. 2019, 91, 262-273. [CrossRef]

153. Mannino, A.M.; Micheli, C. Ecological function of phenolic compounds from Mediterranean fucoid algae and seagrasses: An overview on the genus Cystoseira sensu lato and Posidonia oceanica (L.) Delile. J. Mar. Sci. Eng. 2020, 8, 19. [CrossRef]

154. Holdt, S.L.; Kraan, S. Bioactive compounds in seaweed: Functional food applications and legislation. J. Appl. Phycol. 2011, 23, 543-598. [CrossRef]

155. Poole, J.; Diop, A.; Rainville, L.C.; Barnabé, S. Bioextracting polyphenols from the brown seaweed Ascophyllum nodosum from Québec's north shore coastline. Ind. Biotechnol. 2019, 15, 212-218. [CrossRef]

156. Wekre, M.E.; Kåsin, K.; Underhaug, J.; Holmelid, B.; Jordheim, M. Quantification of polyphenols in seaweeds: A case study of Ulva intestinalis. Antioxidants 2019, 8, 612. [CrossRef]

157. Quideau, S.; Deffieux, D.; Douat-Casassus, C.; Pouységu, L. Plant polyphenols: Chemical properties, biological activities, and synthesis. Angew. Chem. Int. Ed. 2011, 50, 586-621. [CrossRef]

158. Freile-Pelegrin, Y.; Robledo, D. Chapter 6-Bioactive phenolic compounds from algae. In Bioactive Compounds from Marine Foods: Plant and Animal Sources; Hernández-Ledesma, B., Herrero, M., Eds.; Wiley-Blackwell: Chichester, UK, 2014; pp. 113-129. [CrossRef] 
159. Murray, M.; Dordevic, A.L.; Cox, K.; Scholey, A.; Ryan, L.; Bonham, M.P. Twelve weeks' treatment with a polyphenol-rich seaweed extract increased HDL cholesterol with no change in other biomarkers of chronic disease risk in overweight adults: A placebo-controlled randomised trial. J. Nutr. Biochem. 2021, 108777. [CrossRef] [PubMed]

160. Haskell-Ramsay, C.F.; Jackson, P.A.; Dodd, F.L.; Forster, J.S.; Bérubé, J.; Levinton, C.; Kennedy, D.O. Acute post-prandial cognitive effects of brown seaweed extract in humans. Nutrients 2018, 10, 85. [CrossRef] [PubMed]

161. Hata, Y.; Nakajima, K.; Uchida, J.-I.; Hidaka, H.; Nakano, T. Clinical effects of brown seaweed, Undaria pinnatifida (wakame), on blood pressure in hypertensive subjects. J. Clin. Biochem. Nutr. 2001, 30, 43-53. [CrossRef]

162. Derosa, G.; Pascuzzo, M.D.; D’Angelo, A.; Maffioli, P. Ascophyllum nodosum, Fucus vesiculosus and chromium picolinate nutraceutical composition can help to treat type 2 diabetic patients. Diabetes. Metab. Syndr. Obes. 2019, 12, 1861-1865. [CrossRef]

163. Murray, M.; Dordevic, A.L.; Ryan, L.; Bonham, M.P. A single-dose of a polyphenol-rich Fucus vesiculosus extract is insufficient to blunt the elevated postprandial blood glucose responses exhibited by healthy adults in the evening: A randomised crossover trial. Antioxidants 2019, 8, 49. [CrossRef]

164. Cardona, F.; Andrés-Lacueva, C.; Tulipani, S.; Tinahones, F.J.; Queipo-Ortuño, M.I. Benefits of polyphenols on gut microbiota and implications in human health. J. Nutr. Biochem. 2013, 24, 1415-1422. [CrossRef]

165. Tomás-Barberán, F.A.; Selma, M.V.; Espín, J.C. Interactions of gut microbiota with dietary polyphenols and consequences to human health. Curr. Opin. Clin. Nutr. Metab. Care 2016, 19, 471-476. [CrossRef]

166. Kumar Singh, A.; Cabral, C.; Kumar, R.; Ganguly, R.; Kumar Rana, H.; Gupta, A.; Rosaria Lauro, M.; Carbone, C.; Reis, F.; Pandey, A.K. Beneficial effects of dietary polyphenols on gut microbiota and strategies to improve delivery efficiency. Nutrients 2019, 11, 2216. [CrossRef]

167. Stevens, J.F.; Maier, C.S. The chemistry of gut microbial metabolism of polyphenols. Phytochem. Rev. 2016, 15, 425-444. [CrossRef] [PubMed]

168. Selma, M.V.; Espin, J.C.; Tomas-Barberan, F.A. Interaction between phenolics and gut microbiota: Role in human health. J. Agric. Food. Chem. 2009, 57, 6485-6501. [CrossRef] [PubMed]

169. Samanta, A.; Das, G.; Das, S.K. Roles of flavonoids in plants. Int. J. Pharm. Sci. Tech. 2011, 6, 12-35. Available online: https:/ / www.researchgate.net/profile/Sanjoy_Das10/publication/279499208_Roles_of_flavonoids_in_Plants/links/56 67098108ae8905db8b8b47.pdf (accessed on 27 July 2020).

170. Lin, G.; Liu, X.; Yan, X.; Liu, D.; Yang, C.; Liu, B.; Huang, Y.; Zhao, C. Role of green macroalgae Enteromorpha prolifera polyphenols in the modulation of gene expression and intestinal microflora profiles in type 2 diabetic mice. Int. J. Mol. Sci. 2019, 20, 25. [CrossRef] [PubMed]

171. Yoshie-Stark, Y.; Hsieh, Y.-P.; Suzuki, T. Distribution of flavonoids and related compounds from seaweeds in Japan. J. Tokyo Univ. Fish. 2003, 89, 1-6. Available online: https://www.researchgate.net/publication/285022048_Distribution_of_flavonoids_and_ related_compounds_from_seaweeds_in_Japan (accessed on 3 July 2020).

172. Culioli, G.; Ortalo-Magné, A.; Valls, R.; Hellio, C.; Clare, A.S.; Piovetti, L. Antifouling activity of meroditerpenoids from the marine brown alga Halidrys siliquosa. J. Nat. Prod. 2008, 71, 1121-1126. [CrossRef] [PubMed]

173. Gómez-Guzmán, M.; Rodríguez-Nogales, A.; Algieri, F.; Gálvez, J. Potential role of seaweed polyphenols in cardiovascularassociated disorders. Mar. Drugs 2018, 16, 250. [CrossRef]

174. Dong, H.; Dong, S.; Erik Hansen, P.; Stagos, D.; Lin, X.; Liu, M. Progress of bromophenols in marine algae from 2011 to 2020 : Structure, bioactivities, and applications. Mar. Drugs 2020, 18, 411. [CrossRef]

175. Shibata, T.; Miyasaki, T.; Miyake, H.; Tanaka, R.; Kawaguchi, S. The influence of phlorotannins and bromophenols on the feeding behavior of marine herbivorous gastropod Turbo cornutus. Am. J. Plant Sci. 2014, 5, 387-392. [CrossRef]

176. Nielsen, B.V.; Maneein, S.; Farid, A.; Mahmud, M.; Milledge, J.J. The effects of halogenated compounds on the anaerobic digestion of macroalgae. Fermentation 2020, 6, 85. [CrossRef]

177. Hay, M.E.; Fenical, W. Marine plant-herbivore interactions: The ecology of chemical defense. Annu. Rev. Ecol. Syst. 1988, 19, 111-145. [CrossRef]

178. Whitfield, F.; Helidoniotis, F.; Drew, M. Effect of Diet and Environment on the Volatile Flavour Components of Crustaceans; CSIRO and Fisheries Research \& Development Corporation: North Ryde, NSW, Australia, 1995. Available online: http:/ / www.frdc.com.au/ Archived-Reports /FRDC\%20Projects /1992-075-DLD.pdf (accessed on 8 June 2020).

179. Whitfield, F.B.; Helidoniotis, F.; Shaw, K.J.; Svoronos, D. Distribution of bromophenols in species of marine algae from eastern Australia. J. Agric. Food. Chem. 1999, 47, 2367-2373. [CrossRef]

180. Luo, J.; Xu, Q.; Jiang, B.; Zhang, R.; Jia, X.; Li, X.; Wang, L.; Guo, C.; Wu, N.; Shi, D. Selectivity, cell permeability and oral availability studies of novel bromophenol derivative HPN as protein tyrosine phosphatase 1B inhibitor. Br. J. Pharmacol. 2018, 175, 140-153. [CrossRef] [PubMed]

181. Zhang, Y.; Glukhov, E.; Yu, H.; Gerwick, L.; Dorrestein, P.; Gerwick, W. Monomeric and dimeric bromophenols from the red alga Ceramium sp. with antioxidant and anti-inflammatory activities. ChemRxiv 2020. [CrossRef]

182. Cherian, C.; Vennila, J.J.; Sharan, L. Marine bromophenols as an effective inhibitor of virulent proteins (peptidyl arginine deiminase, gingipain R and hemagglutinin A) in Porphyromas gingivalis. Arch. Oral Biol. 2019, 100, 119-128. [CrossRef]

183. Shi, D.; Li, J.; Guo, S.; Su, H.; Fan, X. The antitumor effect of bromophenol derivatives in vitro and Leathesia nana extract in vivo. Chin. J. Oceanol. Limnol. 2009, 27, 277-282. [CrossRef] 
184. Shi, D.; Li, X.; Li, J.; Guo, S.; Su, H.; Fan, X. Antithrombotic effects of bromophenol, an alga-derived thrombin inhibitor. Chin. J. Oceanol. Limnol. 2010, 28, 96-98. [CrossRef]

185. Nguyen, T.H.; Nguyen, T.L.P.; Tran, T.V.A.; Do, A.D.; Kim, S.M. Antidiabetic and antioxidant activities of red seaweed Laurencia dendroidea. Asian Pac. J. Trop. Biomed. 2019, 9, 501. [CrossRef]

186. Wang, C.; Jiang, D.; Sun, Y.; Gu, Y.; Ming, Y.; Zheng, J.; Yu, C.; Chen, X.; Qi, H. Synergistic effects of UVA irradiation and phlorotannin extracts of Laminaria japonica on properties of grass carp myofibrillar protein gel. J. Sci. Food Agric. 2020. [CrossRef]

187. Lemesheva, V.; Birkemeyer, C.; Garbary, D.; Tarakhovskaya, E. Vanadium-dependent haloperoxidase activity and phlorotannin incorporation into the cell wall during early embryogenesis of Fucus vesiculosus (Phaeophyceae). Eur. J. Phycol. 2020, 55, 275-284. [CrossRef]

188. Gómez, I.; Huovinen, P. Induction of phlorotannins during UV exposure mitigates inhibition of photosynthesis and DNA damage in the kelp Lessonia nigrescens. Photochem. Photobiol. 2010, 86, 1056-1063. [CrossRef] [PubMed]

189. Arnold, T.M.; Targett, N.M. To grow and defend: Lack of tradeoffs for brown algal phlorotannins. Oikos 2003, 100, 406-408. [CrossRef]

190. Lopes, G.; Barbosa, M.; Vallejo, F.; Gil-Izquierdo, Á.; Andrade, P.B.; Valentão, P.; Pereira, D.M.; Ferreres, F. Profiling phlorotannins from Fucus spp. of the Northern Portuguese coastline: Chemical approach by HPLC-DAD-ESI/MSn and UPLC-ESI-QTOF/MS. Algal Res. 2018, 29, 113-120. [CrossRef]

191. Sonani, R.; Rastogi, R.; Madamwar, D. Chapter 5-Natural Antioxidants From Algae: A Therapeutic Perspective. In Algal Green Chemistry: Recent Progress in Biotechnology; Rastogi, R.P., Madamwar, D., Pandey, A., Eds.; Elsevier: Amsterdam, The Netherlands, 2017; pp. 91-120. [CrossRef]

192. Heffernan, N.; Brunton, N.P.; FitzGerald, R.J.; Smyth, T.J. Profiling of the molecular weight and structural isomer abundance of macroalgae-derived phlorotannins. Mar. Drugs 2015, 13, 509-528. [CrossRef]

193. Steevensz, A.J.; MacKinnon, S.L.; Hankinson, R.; Craft, C.; Connan, S.; Stengel, D.B.; Melanson, J.E. Profiling phlorotannins in brown macroalgae by liquid chromatography-high resolution mass spectrometry. Phytochem. Anal. 2012, 23, 547-553. [CrossRef] [PubMed]

194. Barwell, C.J.; Blunden, G.; Manandhar, P.D. Isolation and characterization of brown algal polyphenols as inhibitors of $\alpha$-amylase, lipase and trypsin. J. Appl. Phycol. 1989, 1, 319-323. [CrossRef]

195. Geiselman, J.A.; McConnell, O.J. Polyphenols in brown algae Fucus vesiculosus and Ascophyllum nodosum: Chemical defenses against the marine herbivorous snail, Littorina littorea. J. Chem. Ecol. 1981, 7, 1115-1133. [CrossRef]

196. Connan, S.; Goulard, F.; Stiger, V.; Deslandes, E.; Gall, E.A. Interspecific and temporal variation in phlorotannin levels in an assemblage of brown algae. Bot. Mar. 2004, 47, 410-416. [CrossRef]

197. Kim, S.M.; Kang, S.W.; Jeon, J.-S.; Jung, Y.-J.; Kim, W.-R.; Kim, C.Y.; Um, B.-H. Determination of major phlorotannins in Eisenia bicyclis using hydrophilic interaction chromatography: Seasonal variation and extraction characteristics. Food Chem. 2013, 138, 2399-2406. [CrossRef]

198. Li, Y.; Fu, X.; Duan, D.; Liu, X.; Xu, J.; Gao, X. Extraction and identification of phlorotannins from the brown alga, Sargassum fusiforme (Harvey) Setchell. Mar. Drugs 2017, 15, 49. [CrossRef]

199. Lee, S.-H.; Yong-Li; Karadeniz, F.; Kim, M.-M.; Kim, S.-K. $\alpha$-Glucosidase and $\alpha$-amylase inhibitory activities of phloroglucinal derivatives from edible marine brown alga, Ecklonia cava. J. Sci. Food Agric. 2009, 89, 1552-1558. [CrossRef]

200. Abdelhamid, A.; Lajili, S.; Elkaibi, M.; Muller, C.; Majdoub, H.; Jamil, K.; Bouraoui, A. Optimized extraction, preliminary characterization and evaluation of the in vitro anticancer activity of phlorotannin-rich fraction from the brown seaweed, Cystoseira sedoides. J. Aquat. Food Prod. Technol. 2019, 28, 892-909. [CrossRef]

201. Kim, H.-J.; Yong, H.I.; Lee, B.W.; Park, S.; Baek, K.H.; Kim, T.H.; Jo, C. Plasma-polymerized phlorotannins and their enhanced biological activities. J. Agric. Food. Chem. 2020, 68, 2357-2365. [CrossRef]

202. Dong, X.; Bai, Y.; Xu, Z.; Shi, Y.; Sun, Y.; Janaswamy, S.; Yu, C.; Qi, H. Phlorotannins from Undaria pinnatifida sporophyll: Extraction, antioxidant, and anti-inflammatory activities. Mar. Drugs 2019, 17, 434. [CrossRef]

203. Artan, M.; Li, Y.; Karadeniz, F.; Lee, S.-H.; Kim, M.-M.; Kim, S.-K. Anti-HIV-1 activity of phloroglucinol derivative, 6,6'-bieckol, from Ecklonia cava. Biorg. Med. Chem. 2008, 16, 7921-7926. [CrossRef] [PubMed]

204. Zhou, X.; Yi, M.; Ding, L.; He, S.; Yan, X. Isolation and Purification of a neuroprotective phlorotannin from the marine algae Ecklonia maxima by size exclusion and high-speed counter-current chromatography. Mar. Drugs 2019, 17, 212. [CrossRef]

205. Tang, J.; Wang, W.; Chu, W. Antimicrobial and anti-quorum sensing activities of phlorotannins from seaweed (Hizikia fusiforme). Front. Cell. Infect. Microbiol. 2020, 10. [CrossRef] [PubMed]

206. Corona, G.; Ji, Y.; Anegboonlap, P.; Hotchkiss, S.; Gill, C.; Yaqoob, P.; Spencer, J.P.; Rowland, I. Gastrointestinal modifications and bioavailability of brown seaweed phlorotannins and effects on inflammatory markers. Br. J. Nutr. 2016, 115, 1240-1253. [CrossRef]

207. Wang, Y.; Xu, Z.; Bach, S.J.; McAllister, T.A. Effects of phlorotannins from Ascophyllum nodosum (brown seaweed) on in vitro ruminal digestion of mixed forage or barley grain. Anim. Feed Sci. Technol. 2008, 145, 375-395. [CrossRef]

208. Zhao, C.; Yang, C.; Chen, M.; Lv, X.; Liu, B.; Yi, L.; Cornara, L.; Wei, M.-C.; Yang, Y.-C.; Tundis, R.; et al. Regulatory efficacy of brown seaweed Lessonia nigrescens extract on the gene expression profile and intestinal microflora in type 2 diabetic mice. Mol. Nutr. Food Res. 2018, 62, 1700730. [CrossRef] 
209. Hirosumi, J.; Tuncman, G.; Chang, L.; Görgün, C.Z.; Uysal, K.T.; Maeda, K.; Karin, M.; Hotamisligil, G.S. A central role for JNK in obesity and insulin resistance. Nature 2002, 420, 333-336. [CrossRef] [PubMed]

210. Yuan, Y.; Zheng, Y.; Zhou, J.; Geng, Y.; Zou, P.; Li, Y.; Zhang, C. Polyphenol-rich extracts from brown macroalgae Lessonia trabeculate attenuate hyperglycemia and modulate gut microbiota in high-fat diet and streptozotocin-induced diabetic rats. J. Agric. Food. Chem. 2019, 67, 12472-12480. [CrossRef] [PubMed]

211. Xu, J.; Liu, T.; Li, Y.; Yuan, C.; Ma, H.; Seeram, N.P.; Liu, F.; Mu, Y.; Huang, X.; Li, L. Hypoglycemic and hypolipidemic effects of triterpenoid-enriched Jamun (Eugenia jambolana Lam.) fruit extract in streptozotocin-induced type 1 diabetic mice. Food Funct. 2018, 9, 3330-3337. [CrossRef]

212. Chang, P.V.; Hao, L.; Offermanns, S.; Medzhitov, R. The microbial metabolite butyrate regulates intestinal macrophage function via histone deacetylase inhibition. Proc. Natl Acad. Sci. USA 2014, 111, 2247-2252. [CrossRef] [PubMed]

213. Morgan, X.C.; Tickle, T.L.; Sokol, H.; Gevers, D.; Devaney, K.L.; Ward, D.V.; Reyes, J.A.; Shah, S.A.; LeLeiko, N.; Snapper, S.B.; et al. Dysfunction of the intestinal microbiome in inflammatory bowel disease and treatment. Genome Biol. 2012, 13, R79. [CrossRef]

214. Do, M.H.; Lee, H.-B.; Lee, E.; Park, H.-Y. The effects of gelatinized wheat starch and high salt diet on gut microbiota and metabolic disorder. Nutrients 2020, 12, 301. [CrossRef]

215. Wu, T.-R.; Lin, C.-S.; Chang, C.-J.; Lin, T.-L.; Martel, J.; Ko, Y.-F.; Ojcius, D.M.; Lu, C.-C.; Young, J.D.; Lai, H.-C. Gut commensal Parabacteroides goldsteinii plays a predominant role in the anti-obesity effects of polysaccharides isolated from Hirsutella sinensis. Gut 2019, 68, 248-262. [CrossRef]

216. Corona, G.; Coman, M.; Guo, Y.; Hotchkiss, S.; Gill, C.; Yaqoob, P.; Spencer, J.; Rowland, I. Effect of simulated gastrointestinal digestion and fermentation on polyphenolic content and bioactivity of brown seaweed phlorotannin-rich extracts. Mol. Nutr. Food Res. 2017, 61, 1700223. [CrossRef] [PubMed]

217. Fitzgerald, C.; Mora-Soler, L.; Gallagher, E.; O'Connor, P.; Prieto, J.; Soler-Vila, A.; Hayes, M. Isolation and characterization of bioactive pro-peptides with in vitro renin inhibitory activities from the macroalga Palmaria palmata. J. Agric. Food. Chem. 2012, 60, 7421-7427. [CrossRef] [PubMed]

218. Harnedy, P.A.; O'Keeffe, M.B.; FitzGerald, R.J. Purification and identification of dipeptidyl peptidase (DPP) IV inhibitory peptides from the macroalga Palmaria palmata. Food Chem. 2015, 172, 400-406. [CrossRef]

219. Fitzgerald, C.; Gallagher, E.; O'Connor, P.; Prieto, J.; Mora-Soler, L.; Grealy, M.; Hayes, M. Development of a seaweed derived platelet activating factor acetylhydrolase (PAF-AH) inhibitory hydrolysate, synthesis of inhibitory peptides and assessment of their toxicity using the Zebrafish larvae assay. Peptides 2013, 50, 119-124. [CrossRef]

220. Admassu, H.; Gasmalla, M.A.; Yang, R.; Zhao, W. Identification of bioactive peptides with $\alpha$-amylase inhibitory potential from enzymatic protein hydrolysates of red seaweed (Porphyra spp). J. Agric. Food. Chem. 2018, 66, 4872-4882. [CrossRef]

221. Cian, R.E.; Hernández-Chirlaque, C.; Gámez-Belmonte, R.; Drago, S.R.; Sánchez de Medina, F.; Martínez-Augustin, O. Green alga Ulva spp. hydrolysates and their peptide fractions regulate cytokine production in splenic macrophages and lymphocytes involving the TLR4-NFkB/MAPK pathways. Mar. Drugs 2018, 16, 235. [CrossRef]

222. Minkova, K.M.; Toshkova, R.A.; Gardeva, E.G.; Tchorbadjieva, M.I.; Ivanova, N.J.; Yossifova, L.S.; Gigova, L.G. Antitumor activity of B-phycoerythrin from Porphyridium cruentum. J. Pharm. Res. 2011, 4, 1480-1482. Available online: https:/ / www.researchgate.net/profile/Liliya_Yossifova/publication/228107475_Antitumor_activity_of_B-phycoerythrin_ from_Porphyridium_cruentum/links/Ofcfd50732fa2025d2000000.pdf (accessed on 16 September 2020).

223. Venkatraman, K.L.; Syed, A.A.; Indumathi, P.; Mehta, A. VITPOR AI, a coagulation factor XIIa inhibitor from Porphyra yezoensis: In vivo mode of action and assessment of platelet function analysis. Protein Pept. Lett. 2020, 27, 243-250. [CrossRef]

224. McLaughlin, C.M.; Sharkey, S.J.; Harnedy-Rothwell, P.; Parthsarathy, V.; Allsopp, P.J.; McSorley, E.M.; FitzGerald, R.J.; O’Harte, F.P.M. Twice daily oral administration of Palmaria palmata protein hydrolysate reduces food intake in streptozotocin induced diabetic mice, improving glycaemic control and lipid profiles. J. Funct. Foods 2020, 73, 104101. [CrossRef]

225. Dave, L.A.; Hayes, M.; Mora, L.; Rutherfurd, S.M.; Montoya, C.A.; Moughan, P.J. Bioactive peptides originating from gastrointestinal endogenous proteins in the growing pig: In vivo identification. Curr. Pharm. Des. 2021, 27, 1382-1395. [CrossRef] [PubMed]

226. Fitzgerald, C.; Aluko, R.E.; Hossain, M.; Rai, D.K.; Hayes, M. Potential of a renin inhibitory peptide from the red seaweed Palmaria palmata as a functional food ingredient following confirmation and characterization of a hypotensive effect in spontaneously hypertensive rats. J. Agric. Food. Chem. 2014, 62, 8352-8356. [CrossRef] [PubMed]

227. Allsopp, P.; Crowe, W.; Bahar, B.; Harnedy, P.A.; Brown, E.S.; Taylor, S.S.; Smyth, T.J.; Soler-Vila, A.; Magee, P.J.; Gill, C.I.R.; et al The effect of consuming Palmaria palmata-enriched bread on inflammatory markers, antioxidant status, lipid profile and thyroid function in a randomised placebo-controlled intervention trial in healthy adults. Eur. J. Nutr. 2016, 55, 1951-1962. [CrossRef] [PubMed]

228. Furuta, T.; Miyabe, Y.; Yasui, H.; Kinoshita, Y.; Kishimura, H. Angiotensin I converting enzyme inhibitory peptides derived from phycobiliproteins of dulse Palmaria palmata. Mar. Drugs 2016, 14, 32. [CrossRef] [PubMed]

229. Sato, M.; Hosokawa, T.; Yamaguchi, T.; Nakano, T.; Muramoto, K.; Kahara, T.; Funayama, K.; Kobayashi, A.; Nakano, T. Angiotensin I-converting enzyme inhibitory peptides derived from Wakame (Undaria pinnatifida) and their antihypertensive effect in spontaneously hypertensive rats. J. Agric. Food. Chem. 2002, 50, 6245-6252. [CrossRef]

230. Suetsuna, K.; Nakano, T. Identification of an antihypertensive peptide from peptic digest of wakame (Undaria pinnatifida). J. Nutr. Biochem. 2000, 11, 450-454. [CrossRef] 
231. Harnedy, P.A.; O'Keeffe, M.B.; FitzGerald, R.J. Fractionation and identification of antioxidant peptides from an enzymatically hydrolysed Palmaria palmata protein isolate. Food Res. Int. 2017, 100, 416-422. [CrossRef]

232. Amaretti, A.; Gozzoli, C.; Simone, M.; Raimondi, S.; Righini, L.; Pérez-Brocal, V.; García-López, R.; Moya, A.; Rossi, M. Profiling of protein degraders in cultures of human gut microbiota. Front. Microbiol. 2019, 10. [CrossRef]

233. Neis, E.P.J.G.; Dejong, C.H.C.; Rensen, S.S. The role of microbial amino acid metabolism in host metabolism. Nutrients 2015, 7 , 2930-2946. [CrossRef]

234. Diether, N.E.; Willing, B.P. Microbial fermentation of dietary protein: An important factor in diet-microbe-host interaction. Microorganisms 2019, 7, 19. [CrossRef]

235. Fan, P.; Li, L.; Rezaei, A.; Eslamfam, S.; Che, D.; Ma, X. Metabolites of dietary protein and peptides by intestinal microbes and their impacts on gut. Curr. Protein Pept. Sci. 2015, 16, 646-654. [CrossRef]

236. Oliphant, K.; Allen-Vercoe, E. Macronutrient metabolism by the human gut microbiome: Major fermentation by-products and their impact on host health. Microbiome 2019, 7, 91. [CrossRef] [PubMed]

237. Kim, J.; Hetzel, M.; Boiangiu, C.D.; Buckel, W. Dehydration of (R)-2-hydroxyacyl-CoA to enoyl-CoA in the fermentation of $\alpha$-amino acids by anaerobic bacteria. FEMS Microbiol. Rev. 2004, 28, 455-468. [CrossRef] [PubMed]

238. Blachier, F.; Mariotti, F.; Huneau, J.F.; Tomé, D. Effects of amino acid-derived luminal metabolites on the colonic epithelium and physiopathological consequences. Amino Acids 2007, 33, 547-562. [CrossRef] [PubMed]

239. Feng, W.; Ao, H.; Peng, C. Gut microbiota, short-chain fatty acids, and herbal medicines. Front. Pharmacol. 2018, 9, 1354. [CrossRef]

240. Portune, K.J.; Beaumont, M.; Davila, A.-M.; Tomé, D.; Blachier, F.; Sanz, Y. Gut microbiota role in dietary protein metabolism and health-related outcomes: The two sides of the coin. Trends Food Sci. Technol. 2016, 57 Pt B, 213-232. [CrossRef]

241. Yao, C.K.; Muir, J.G.; Gibson, P.R. Review article: Insights into colonic protein fermentation, its modulation and potential health implications. Aliment. Pharmacol. Ther. 2016, 43, 181-196. [CrossRef] [PubMed]

242. Korpela, K. Diet, microbiota, and metabolic health: Trade-off between saccharolytic and proteolytic fermentation. Annu. Rev. Food Sci. Technol. 2018, 9, 65-84. [CrossRef]

243. Wang, X.; Gibson, G.R.; Costabile, A.; Sailer, M.; Theis, S.; Rastall, R.A. Prebiotic supplementation of in vitro fecal fermentations inhibits proteolysis by gut bacteria, and host diet shapes gut bacterial metabolism and response to intervention. Appl. Environ. Microbiol. 2019, 85, e02749-18. [CrossRef]

244. Lee, M.K.; Kim, I.H.; Choi, Y.H.; Nam, T.J. A peptide from Porphyra yezoensis stimulates the proliferation of IEC-6 cells by activating the insulin-like growth factor I receptor signaling pathway. Int. J. Mol. Med. 2015, 35, 533-538. [CrossRef]

245. Remacle-Bonnet, M.; Garrouste, F.; Baillat, G.; Andre, F.; Marvaldi, J.; Pommier, G. Membrane rafts segregate pro- from antiapoptotic insulin-like growth factor-I receptor signaling in colon carcinoma cells stimulated by members of the tumor necrosis factor superfamily. Am. J. Pathol. 2005, 167, 761-773. [CrossRef]

246. Braicu, C.; Buse, M.; Busuioc, C.; Drula, R.; Gulei, D.; Raduly, L.; Rusu, A.; Irimie, A.; Atanasov, A.G.; Slaby, O.; et al. A comprehensive review on MAPK: A promising therapeutic target in cancer. Cancers 2019, 11, 1618. [CrossRef]

247. Lee, M.-K.; Kim, I.-H.; Choi, Y.-H.; Choi, J.-W.; Kim, Y.-M.; Nam, T.-J. The proliferative effects of Pyropia yezoensis peptide on IEC-6 cells are mediated through the epidermal growth factor receptor signaling pathway. Int. J. Mol. Med. 2015, 35, 909-914. [CrossRef] [PubMed]

248. Katz, M.; Amit, I.; Yarden, Y. Regulation of MAPKs by growth factors and receptor tyrosine kinases. Biochim. Biophys. Acta Bioenerg. 2007, 1773, 1161-1176. [CrossRef]

249. Li, L.; Zhao, G.D.; Shi, Z.; Qi, L.L.; Zhou, L.Y.; Fu, Z.X. The Ras/Raf/MEK/ERK signaling pathway and its role in the occurrence and development of HCC. Oncol. Lett. 2016, 12, 3045-3050. [CrossRef] [PubMed]

250. Klopfleisch, R.; Gruber, A.D. Differential expression of cell cycle regulators p21, p27 and p53 in metastasizing canine mammary adenocarcinomas versus normal mammary glands. Res. Vet. Sci. 2009, 87, 91-96. [CrossRef]

251. Paunovic, B.; Khomenko, T.; Deng, X.; Xiong, X.; Sandor, Z.; Szabo, S. Overexpression of cyclin-dependent kinase (CDK) inhibitors p21 and p27 is a common mechanism of experimental duodenal ulcer and ulcerative colitis. FASEB J. 2010, 24, 1027.4. [CrossRef]

252. Abdelhedi, O.; Nasri, M. Basic and recent advances in marine antihypertensive peptides: Production, structure-activity relationship and bioavailability. Trends Food Sci. Technol. 2019, 88, 543-557. [CrossRef]

253. Samarakoon, K.; Jeon, Y.-J. Bio-functionalities of proteins derived from marine algae: A review. Food Res. Int. 2012, 48, 948-960. [CrossRef]

254. Vizcaíno, A.J.; Galafat, A.; Sáez, M.I.; Martínez, T.F.; Alarcón, F.J. Partial characterization of protease inhibitors of Ulva ohnoi and their effect on digestive proteases of marine fish. Mar. Drugs 2020, 18, 319. [CrossRef]

255. Mahomoodally, M.F.; Bibi Sadeer, N.; Zengin, G.; Cziáky, Z.; Jekő, J.; Diuzheva, A.; Sinan, K.I.; Palaniveloo, K.; Kim, D.H.; Rengasamy, K.R.R. In vitro enzyme inhibitory properties, secondary metabolite profiles and multivariate analysis of five seaweeds. Mar. Drugs 2020, 18, 198. [CrossRef]

256. Pan, S.; Wang, S.; Jing, L.; Yao, D. Purification and characterisation of a novel angiotensin-I converting enzyme (ACE)-inhibitory peptide derived from the enzymatic hydrolysate of Enteromorpha clathrata protein. Food Chem. 2016, 211, 423-430. [CrossRef]

257. Rein, M.J.; Renouf, M.; Cruz-Hernandez, C.; Actis-Goretta, L.; Thakkar, S.K.; da Silva Pinto, M. Bioavailability of bioactive food compounds: A challenging journey to bioefficacy. Br. J. Clin. Pharmacol. 2013, 75, 588-602. [CrossRef] 
258. Nova, P.; Pimenta-Martins, A.; Laranjeira Silva, J.; Silva, A.M.; Gomes, A.M.; Freitas, A.C. Health benefits and bioavailability of marine resources components that contribute to health-what's new? Crit. Rev. Food Sci. Nutr. 2020, 1-13. [CrossRef]

259. Thakur, N.; Raigond, P.; Singh, Y.; Mishra, T.; Singh, B.; Lal, M.K.; Dutt, S. Recent updates on bioaccessibility of phytonutrients. Trends Food Sci. Technol. 2020, 97, 366-380. [CrossRef]

260. Alegría, A.; Garcia-Llatas, G.; Cilla, A. Chapter 1-Static digestion models: General introduction. In The Impact of Food Bioactives on Health: In Vitro and Ex Vivo Models; Verhoeckx, K., Cotter, P., López-Expósito, I., Kleiveland, C., Lea, T., Mackie, A., Requena, T., Swiatecka, D., Wichers, H., Eds.; Springer: Cham, Switzerland, 2015; pp. 3-12. [CrossRef]

261. Plank, D.W. In Vitro Method for Estimating In Vivo Protein Digestibility; General Mills Inc.: Minneapolis, MN, USA, 2017. Available online: https:/ / patents.google.com/patent/US9738920B2/en (accessed on 19 July 2020).

262. Bohn, T.; Carrière, F.; Day, L.; Deglaire, A.; Egger, L.; Freitas, D.; Golding, M.; Lefeunteun, S.; Macierzanka, A.; Ménard, O.; et al. Correlation between in vitro and in vivo data on food digestion. What can we predict with static in vitro digestion models? Crit. Rev. Food Sci. Nutr. 2017, 58, 2239-2261. [CrossRef] [PubMed]

263. Dima, C.; Assadpour, E.; Dima, S.; Jafari, S.M. Bioavailability and bioaccessibility of food bioactive compounds; overview and assessment by in vitro methods. Compr. Rev. Food Sci. Food Saf. 2020, 19, 2862-2884. [CrossRef] [PubMed]

264. Alminger, M.; Aura, A.-M.; Bohn, T.; Dufour, C.; El, S.N.; Gomes, A.; Karakaya, S.; Martínez-Cuesta, M.C.; McDougall, G.J.; Requena, T.; et al. In vitro models for studying secondary plant metabolite digestion and bioaccessibility. Compr. Rev. Food Sci. Food Saf. 2014, 13, 413-436. [CrossRef]

265. Egger, L.; Ménard, O.; Delgado-Andrade, C.; Alvito, P.; Assunção, R.; Balance, S.; Barberá, R.; Brodkorb, A.; Cattenoz, T.; Clemente, A.; et al. The harmonized INFOGEST in vitro digestion method: From knowledge to action. Food Res. Int. 2016, 88, 217-225. [CrossRef]

266. Etcheverry, P.; Grusak, M.A.; Fleige, L.E. Application of in vitro bioaccessibility and bioavailability methods for calcium, carotenoids, folate, iron, magnesium, polyphenols, zinc, and vitamins B6, B12, D, and E. Front. Physiol. 2012, 3, 317. [CrossRef] [PubMed]

267. Laparra, J.M.; Vélez, D.; Montoro, R.; Barberá, R.; Farré, R. Estimation of arsenic bioaccessibility in edible seaweed by an in vitro digestion method. J. Agric. Food. Chem. 2003, 51, 6080-6085. [CrossRef] [PubMed]

268. Miller, D.D.; Schricker, B.R.; Rasmussen, R.R.; Van Campen, D. An in vitro method for estimation of iron availability from meals. Am. J. Clin. Nutr. 1981, 34, 2248-2256. [CrossRef]

269. Minekus, M.; Alminger, M.; Alvito, P.; Ballance, S.; Bohn, T.; Bourlieu, C.; Carriere, F.; Boutrou, R.; Corredig, M.; Dupont, D. A standardised static in vitro digestion method suitable for food-an international consensus. Food Funct. 2014, 5, 1113-1124. [CrossRef]

270. Boisen, S.; Eggum, B. Critical evaluation of in vitro methods for estimating digestibility in simple-stomach animals. Nutr. Res. Rev. 1991, 4, 141-162. [CrossRef] [PubMed]

271. Dupont, D.; Bordoni, A.; Brodkorb, A.; Capozzi, F.; Velickovic, T.C.; Corredig, M.; Cotter, P.D.; De Noni, I.; Gaudichon, C.; Golding, M. An international network for improving health properties of food by sharing our knowledge on the digestive process. Food Dig. 2011, 2, 23-25. [CrossRef]

272. Afonso, C.; Cardoso, C.; Ripol, A.; Varela, J.; Quental-Ferreira, H.; Pousão-Ferreira, P.; Ventura, M.S.; Delgado, I.M.; Coelho, I.; Castanheira, I.; et al. Composition and bioaccessibility of elements in green seaweeds from fish pond aquaculture. Food Res. Int. 2018, 105, 271-277. [CrossRef]

273. Soukoulis, C.; Tsevdou, M.; Andre, C.M.; Cambier, S.; Yonekura, L.; Taoukis, P.S.; Hoffmann, L. Modulation of chemical stability and in vitro bioaccessibility of beta-carotene loaded in kappa-carrageenan oil-in-gel emulsions. Food Chem. 2017, 220, 208-218. [CrossRef] [PubMed]

274. Kazir, M.; Abuhassira, Y.; Robin, A.; Nahor, O.; Luo, J.; Israel, A.; Golberg, A.; Livney, Y.D. Extraction of proteins from two marine macroalgae, Ulva sp. and Gracilaria sp. for food application, and evaluating digestibility, amino acid composition and antioxidant properties of the protein concentrates. Food Hydrocoll. 2019, 87, 194-203. [CrossRef]

275. Guerra, A.; Etienne-Mesmin, L.; Livrelli, V.; Denis, S.; Blanquet-Diot, S.; Alric, M. Relevance and challenges in modeling human gastric and small intestinal digestion. Trends Biotechnol. 2012, 30, 591-600. [CrossRef] [PubMed]

276. Thuenemann, E.C.; Mandalari, G.; Rich, G.T.; Faulks, R.M. Chapter 6-Dynamic gastric model (DGM). In The Impact of Food Bioactives on Health: In Vitro and Ex Vivo Models; Verhoeckx, K., Cotter, P., López-Expósito, I., Kleiveland, C., Lea, T., Mackie, A., Requena, T., Swiatecka, D., Wichers, H., Eds.; Springer: Cham, Switzerland, 2015; pp. 47-59. [CrossRef]

277. Minekus, M.; Marteau, P.; Havenaar, R.; Veld, J.H.H.I.T. A multicompartmental dynamic computer-controlled model simulating the stomach and small intestine. Altern. Lab. Anim. 1995, 23, 197-209. [CrossRef]

278. Etienne-Mesmin, L.; Livrelli, V.; Privat, M.; Denis, S.; Cardot, J.-M.; Alric, M.; Blanquet-Diot, S. Effect of a new probiotic Saccharomyces cerevisiae strain on survival of Escherichia coli 0157:H7 in a dynamic gastrointestinal model. Appl. Environ. Microbiol. 2011, 77, 1127-1131. [CrossRef]

279. Larsson, M.; Minekus, M.; Havenaar, R. Estimation of the bioavailability of iron and phosphorus in cereals using a dynamic in vitro gastrointestinal model. J. Sci. Food Agric. 1997, 74, 99-106. [CrossRef]

280. Verwei, M.; Freidig, A.P.; Havenaar, R.; Groten, J.P. Predicted serum folate concentrations based on in vitro studies and kinetic modeling are consistent with measured folate concentrations in humans. J. Nutr. 2006, 136, 3074-3078. [CrossRef] [PubMed] 
281. Mateo Anson, N.; Havenaar, R.; Bast, A.; Haenen, G.R.M.M. Antioxidant and anti-inflammatory capacity of bioaccessible compounds from wheat fractions after gastrointestinal digestion. J. Cereal Sci. 2010, 51, 110-114. [CrossRef]

282. Torres-Escribano, S.; Denis, S.; Blanquet-Diot, S.; Calatayud, M.; Barrios, L.; Vélez, D.; Alric, M.; Montoro, R. Comparison of a static and a dynamic in vitro model to estimate the bioaccessibility of $\mathrm{As}, \mathrm{Cd}, \mathrm{Pb}$ and $\mathrm{Hg}$ from food reference materials Fucus sp. (IAEA-140/TM) and Lobster hepatopancreas (TORT-2). Sci. Total Environ. 2011, 409, 604-611. [CrossRef] [PubMed]

283. Bellmann, S.; Miyazaki, K.; Chonan, O.; Ishikawa, F.; Havenaar, R. Fucoidan from Cladosiphon okamuranus Tokida added to food has no adverse effect on availability for absorption of divalent minerals in the dynamic multicompartmental model of the upper gastrointestinal tract. Food Digestion 2014, 5, 19-25. [CrossRef]

284. Blanquet, S.; Zeijdner, E.; Beyssac, E.; Meunier, J.-P.; Denis, S.; Havenaar, R.; Alric, M. A dynamic artificial gastrointestinal system for studying the behavior of orally administered drug dosage forms under various physiological conditions. Pharm. Res. 2004, 21, 585-591. [CrossRef] [PubMed]

285. Wickham, M.; Faulks, R.; Mann, J.; Mandalari, G. The design, operation, and application of a dynamic gastric model. Dissolut. Technol. 2012, 19, 15-22. [CrossRef]

286. Vardakou, M.; Mercuri, A.; Barker, S.; Craig, D.; Faulks, R.; Wickham, M. Achieving antral grinding forces in biorelevant in vitro models: Comparing the USP Dissolution Apparatus II and the Dynamic Gastric Model with human in vivo data. AAPS PharmSciTech. 2011, 12, 620-626. [CrossRef]

287. Marciani, L.; Gowland, P.A.; Fillery-Travis, A.; Manoj, P.; Wright, J.; Smith, A.; Young, P.; Moore, R.; Spiller, R.C. Assessment of antral grinding of a model solid meal with echo-planar imaging. Am. J. Physiol. Gastrointest. Liver Physiol. 2001, 280, G844-G849. [CrossRef]

288. Lea, T. Chapter 9-Epithelial cell models; general introduction. In The Impact of Food Bioactives on Health: In Vitro and Ex Vivo Models; Verhoeckx, K., Cotter, P., López-Expósito, I., Kleiveland, C., Lea, T., Mackie, A., Requena, T., Swiatecka, D., Wichers, H., Eds.; Springer: Cham, Switzerland, 2015; pp. 95-102. [CrossRef]

289. Lv, Q.; He, Q.; Wu, Y.; Chen, X.; Ning, Y.; Chen, Y. Investigating the bioaccessibility and bioavailability of cadmium in a cooked rice food matrix by using an 11-day rapid Caco-2/HT-29 co-culture cell model combined with an in vitro digestion model. Biol. Trace Elem. Res. 2019, 190, 336-348. [CrossRef]

290. Kuhre, R.E.; Wewer Albrechtsen, N.J.; Deacon, C.F.; Balk-Møller, E.; Rehfeld, J.F.; Reimann, F.; Gribble, F.M.; Holst, J.J. Peptide production and secretion in GLUTag, NCI-H716, and STC-1 cells: A comparison to native L-cells. J. Mol. Endocrinol. 2016, 56, 201-211. [CrossRef]

291. Reggi, S.; Giromini, C.; Dell'Anno, M.; Baldi, A.; Rebucci, R.; Rossi, L. In vitro digestion of chestnut and quebracho tannin extracts: Antimicrobial effect, antioxidant capacity and cytomodulatory activity in swine intestinal IPEC-J2 cells. Animals 2020, 10, 195. [CrossRef]

292. Sambuy, Y.; De Angelis, I.; Ranaldi, G.; Scarino, M.L.; Stammati, A.; Zucco, F. The Caco-2 cell line as a model of the intestinal barrier: Influence of cell and culture-related factors on Caco-2 cell functional characteristics. Cell Biol. Toxicol. 2005, 21, 1-26. [CrossRef]

293. Glahn, R.P.; Wien, E.M.; van Campen, D.R.; Miller, D.D. Caco-2 cell iron uptake from meat and casein digests parallels in vivo studies: Use of a novel in vitro method for rapid estimation of iron bioavailability. J. Nutr. 1996, 126, 332-339. [CrossRef]

294. Trigo, J.P.; Engström, N.; Steinhagen, S.; Juul, L.; Harrysson, H.; Toth, G.B.; Pavia, H.; Scheers, N.; Undeland, I. In vitro digestibility and Caco-2 cell bioavailability of sea lettuce (Ulva fenestrata) proteins extracted using pH-shift processing. Food Chem. 2021, 356, 129683. [CrossRef]

295. Flores, S.R.L.; Dobbs, J.; Dunn, M.A. Mineral nutrient content and iron bioavailability in common and Hawaiian seaweeds assessed by an in vitro digestion/Caco-2 cell model. J. Food Compos. Anal. 2015, 43, 185-193. [CrossRef]

296. Domínguez-González, M.R.; Chiocchetti, G.M.; Herbello-Hermelo, P.; Vélez, D.; Devesa, V.; Bermejo-Barrera, P. Evaluation of iodine bioavailability in seaweed using in vitro methods. J. Agric. Food. Chem. 2017, 65, 8435-8442. [CrossRef] [PubMed]

297. Hur, S.J.; Lim, B.O.; Decker, E.A.; McClements, D.J. In vitro human digestion models for food applications. Food Chem. 2011, 125, 1-12. [CrossRef]

298. Boisen, S.; Fernández, J.A. Prediction of the total tract digestibility of energy in feedstuffs and pig diets by in vitro analyses. Anim. Feed Sci. Technol. 1997, 68, 277-286. [CrossRef]

299. Hayes, M. Food proteins and bioactive peptides: New and novel sources, characterisation strategies and applications. Foods 2018, 7, 38. [CrossRef]

300. Popova, A.; Mihaylova, D. Antinutrients in plant-based foods: A review. Open Biotechnol. J. 2019, 13, 68-76. [CrossRef]

301. Fabiano, A.; Brilli, E.; Mattii, L.; Testai, L.; Moscato, S.; Citi, V.; Tarantino, G.; Zambito, Y. Ex vivo and in vivo study of Sucrosomial ${ }^{\circledR}$ iron intestinal absorption and bioavailability. Int. J. Mol. Sci. 2018, 19, 2722. [CrossRef]

302. Ussing, H.H. The active ion transport through the isolated frog skin in the light of tracer studies. Acta Physiol. Scand. 1949, 17, 1-37. [CrossRef] [PubMed]

303. Clarke, L.L. A guide to Ussing chamber studies of mouse intestine. Am. J. Physiol. Gastrointest. Liver Physiol. 2009, 296, G1151-G1166. [CrossRef] [PubMed]

304. Awati, A.; Rutherfurd, S.M.; Plugge, W.; Reynolds, G.W.; Marrant, H.; Kies, A.K.; Moughan, P.J. Ussing chamber results for amino acid absorption of protein hydrolysates in porcine jejunum must be corrected for endogenous protein. J. Sci. Food Agric. 2009, 89, 1857-1861. [CrossRef] 
305. Westerhout, J.; Wortelboer, H.; Verhoeckx, K. Chapter 24-Ussing chamber. In The Impact of Food Bioactives on Health: In Vitro and Ex Vivo Models; Verhoeckx, K., Cotter, P., López-Expósito, I., Kleiveland, C., Lea, T., Mackie, A., Requena, T., Swiatecka, D., Wichers, H., Eds.; Springer: Cham, Switzerland, 2015; pp. 263-273. [CrossRef]

306. Luo, Z.; Liu, Y.; Zhao, B.; Tang, M.; Dong, H.; Zhang, L.; Lv, B.; Wei, L. Ex vivo and in situ approaches used to study intestinal absorption. J. Pharmacol. Toxicol. Methods 2013, 68, 208-216. [CrossRef]

307. Agar, W.T.; Hird, F.J.R.; Sidhu, G.S. The uptake of amino acids by the intestine. Biochim. Biophys. Acta 1954, 14, 80-84. [CrossRef]

308. Hillgren, K.M.; Kato, A.; Borchardt, R.T. In vitro systems for studying intestinal drug absorption. Med. Res. Rev. 1995, 15, 83-109. [CrossRef]

309. Nossol, C.; Barta-Böszörményi, A.; Kahlert, S.; Zuschratter, W.; Faber-Zuschratter, H.; Reinhardt, N.; Ponsuksili, S.; Wimmers, K.; Diesing, A.-K.; Rothkötter, H.-J. Comparing two intestinal porcine epithelial cell lines (IPECs): Morphological differentiation, function and metabolism. PLoS ONE 2015, 10, e0132323. [CrossRef]

310. Ripken, D.; Hendriks, H. Chapter 23-Porcine ex vivo intestinal segment model. In The Impact of Food Bioactives on Health: In Vitro and Ex Vivo Models; Verhoeckx, K., Cotter, P., López-Expósito, I., Kleiveland, C., Lea, T., Mackie, A., Requena, T., Swiatecka, D., Wichers, H., Eds.; Springer: Cham, Switzerland, 2015; pp. 255-262. [CrossRef]

311. Pearce, S.C.; Coia, H.G.; Karl, J.P.; Pantoja-Feliciano, I.G.; Zachos, N.C.; Racicot, K. Intestinal in vitro and ex vivo models to study host-microbiome interactions and acute stressors. Front. Physiol. 2018, 9. [CrossRef]

312. Roeselers, G.; Ponomarenko, M.; Lukovac, S.; Wortelboer, H.M. Ex vivo systems to study host-microbiota interactions in the gastrointestinal tract. Best Pract. Res. Clin. Gastroenterol. 2013, 27, 101-113. [CrossRef]

313. van de Merbel, A.F.; van der Horst, G.; van der Mark, M.H.; van Uhm, J.I.M.; van Gennep, E.J.; Kloen, P.; Beimers, L.; Pelger, R.C.M.; van der Pluijm, G. An ex vivo tissue culture model for the assessment of individualized drug responses in prostate and bladder cancer. Front. Oncol. 2018, 8. [CrossRef]

314. Ripken, D.; van der Wielen, N.; Wortelboer, H.M.; Meijerink, J.; Witkamp, R.F.; Hendriks, H.F.J. Steviol glycoside rebaudioside a induces glucagon-like peptide-1 and peptide yy release in a porcine ex vivo intestinal model. J. Agric. Food. Chem. 2014, 62, 8365-8370. [CrossRef] [PubMed]

315. Aura, A.-M.; Maukonen, J. Chapter 25-One compartment fermentation model. In The Impact of Food Bioactives on Health: In Vitro and Ex Vivo Models; Verhoeckx, K., Cotter, P., López-Expósito, I., Kleiveland, C., Lea, T., Mackie, A., Requena, T., Swiatecka, D., Wichers, H., Eds.; Springer: Cham, Switzerland, 2015; pp. 281-292. [CrossRef]

316. Ouwehand, A.C.; Tiihonen, K.; Mäkeläinen, H.; Rautonen, N.; Hasselwander, O.; Sworn, G. Chapter 5-Non-starch polysaccharides in the gastrointestinal tract. In Designing Functional Foods; McClements, D.J., Decker, E.A., Eds.; Woodhead Publishing: Cambridge, UK, 2009; pp. 126-147. [CrossRef]

317. Gibson, G.R.; Cummings, J.H.; Macfarlane, G.T. Use of a three-stage continuous culture system to study the effect of mucin on dissimilatory sulfate reduction and methanogenesis by mixed populations of human gut bacteria. Appl. Environ. Microbiol. 1988, 54, 2750-2755. [CrossRef]

318. Molly, K.; Vande Woestyne, M.; Verstraete, W. Development of a 5-step multi-chamber reactor as a simulation of the human intestinal microbial ecosystem. Appl. Microbiol. Biotechnol. 1993, 39, 254-258. [CrossRef] [PubMed]

319. Van den Abbeele, P.; Grootaert, C.; Marzorati, M.; Possemiers, S.; Verstraete, W.; Gérard, P.; Rabot, S.; Bruneau, A.; El Aidy, S.; Derrien, M. Microbial community development in a dynamic gut model is reproducible, colon region specific, and selective for Bacteroidetes and Clostridium cluster IX. Appl. Environ. Microbiol. 2010, 76, 5237-5246. [CrossRef] [PubMed]

320. Possemiers, S.; Rabot, S.; Espín, J.C.; Bruneau, A.; Philippe, C.; González-Sarrías, A.; Heyerick, A.; Tomás-Barberán, F.A.; De Keukeleire, D.; Verstraete, W. Eubacterium limosum activates isoxanthohumol from hops (Humulus lupulus L.) into the potent phytoestrogen 8-prenylnaringenin in vitro and in rat intestine. J. Nutr. 2008, 138, 1310-1316. [CrossRef] [PubMed]

321. Van den Abbeele, P.; Roos, S.; Eeckhaut, V.; MacKenzie, D.A.; Derde, M.; Verstraete, W.; Marzorati, M.; Possemiers, S.; Vanhoecke, B.; Van Immerseel, F. Incorporating a mucosal environment in a dynamic gut model results in a more representative colonization by Lactobacilli. Microb. Biotechnol. 2012, 5, 106-115. [CrossRef] [PubMed]

322. Marzorati, M.; Verhelst, A.; Luta, G.; Sinnott, R.; Verstraete, W.; de Wiele, T.V.; Possemiers, S. In vitro modulation of the human gastrointestinal microbial community by plant-derived polysaccharide-rich dietary supplements. Int. J. Food Microbiol. 2010, 139, 168-176. [CrossRef]

323. Fu, Y.; Yin, N.; Cai, X.; Du, H.; Wang, P.; Sultana, M.S.; Sun, G.; Cui, Y. Arsenic speciation and bioaccessibility in raw and cooked seafood: Influence of seafood species and gut microbiota. Environ. Pollut. 2021, 280, 116958. [CrossRef]

324. Calatayud, M.; Xiong, C.; Du Laing, G.; Raber, G.; Francesconi, K.; van de Wiele, T. Salivary and gut microbiomes play a significant role in in vitro oral bioaccessibility, biotransformation, and intestinal absorption of arsenic from food. Environ. Sci. Technol. 2018, 52, 14422-14435. [CrossRef]

325. Boever, P.D.; Wouters, R.; Vermeirssen, V.; Boon, N.; Verstraete, W. Development of a six-stage culture system for simulating the gastrointestinal microbiota of weaned infants. Microb. Ecol. Health Dis. 2001, 13, 111-123. [CrossRef]

326. Van de Wiele, T.; Van den Abbeele, P.; Ossieur, W.; Possemiers, S.; Marzorati, M. Chapter 27-The simulator of the human intestinal microbial ecosystem (SHIME ${ }^{\circledR}$ ). In The Impact of Food Bioactives on Health: In Vitro and Ex Vivo Models; Verhoeckx, K., Cotter, P., López-Expósito, I., Kleiveland, C., Lea, T., Mackie, A., Requena, T., Swiatecka, D., Wichers, H., Eds.; Springer: Cham, Switzerland, 2015; pp. 305-317. [CrossRef] 
327. Williams, C.; Walton, G.; Jiang, L.; Plummer, S.; Garaiova, I.; Gibson, G. Comparative analysis of intestinal tract models. Annu. Rev. Food Sci. Technol. 2015, 6. [CrossRef] [PubMed]

328. Barroso, E.; Cueva, C.; Peláez, C.; Martínez-Cuesta, M.C.; Requena, T. Development of human colonic microbiota in the computer-controlled dynamic SIMulator of the GastroIntestinal tract SIMGI. LWT 2015, 61, 283-289. [CrossRef]

329. Barroso, E.; Cueva, C.; Peláez, C.; Martínez-Cuesta, M.C.; Requena, T. Chapter 28-The computer-controlled multicompartmental dynamic model of the gastrointestinal system SIMGI. In The Impact of Food Bioactives on Health: In Vitro and Ex Vivo Models; Verhoeckx, K., Cotter, P., López-Expósito, I., Kleiveland, C., Lea, T., Mackie, A., Requena, T., Swiatecka, D., Wichers, H., Eds.; Springer: Cham, Switzerland, 2015; pp. 319-327. [CrossRef]

330. Payne, A.; Zihler, A.; Chassard, C.; Lacroix, C. Advances and perspectives in in vitro human gut fermentation modeling. Trends Biotechnol. 2011, 30, 17-25. [CrossRef]

331. Nissen, L.; Casciano, F.; Gianotti, A. Intestinal fermentation in vitro models to study food-induced gut microbiota shift: An updated review. FEMS Microbiol. Lett. 2020, 367. [CrossRef]

332. Wissenbach, D.K.; Oliphant, K.; Rolle-Kampczyk, U.; Yen, S.; Höke, H.; Baumann, S.; Haange, S.B.; Verdu, E.F.; Allen-Vercoe, E.; von Bergen, M. Optimization of metabolomics of defined in vitro gut microbial ecosystems. Int. J. Med. Microbiol. 2016, 306, 280-289. [CrossRef]

333. Marzorati, M.; Vanhoecke, B.; De Ryck, T.; Sadaghian Sadabad, M.; Pinheiro, I.; Possemiers, S.; Van den Abbeele, P.; Derycke, L.; Bracke, M.; Pieters, J.; et al. The HMI ${ }^{\mathrm{TM}}$ module: A new tool to study the Host-Microbiota Interaction in the human gastrointestinal tract in vitro. BMC Microbiol. 2014, 14, 133. [CrossRef]

334. Venema, K.; van den Abbeele, P. Experimental models of the gut microbiome. Best Pract. Res. Clin. Gastroenterol. 2013, 27, 115-126. [CrossRef]

335. Wood, R.J.; Tamura, T. Methodological issues in assessing bioavailability of nutrients and other bioactive substances in dietary supplements: Summary of workshop discussion. J. Nutr. 2001, 131, 1396S-1398S. [CrossRef]

336. Carbonell-Capella, J.M.; Buniowska, M.; Barba, F.J.; Esteve, M.J.; Frígola, A. Analytical methods for determining bioavailability and bioaccessibility of bioactive compounds from fruits and vegetables: A review. Compr. Rev. Food Sci. Food 2014, 13, 155-171. [CrossRef]

337. Jahreis, G.; Hausmann, W.; Kiessling, G.; Franke, K.; Leiterer, M. Bioavailability of iodine from normal diets rich in dairy products-results of balance studies in women. Exp. Clin. Endocrinol. Diabetes 2001, 109, 163-167. [CrossRef]

338. Lu, Y.L.; Li, S.J.; Liu, G.Y.; Li, X.C.; Yang, D.; Jia, J.Y.; Zhang, M.Q.; Zheng, H.C.; Yu, C.; Zhu, F.; et al. Oral bioavailability and mass balance studies of a novel anti-arrhythmic agent sulcardine sulfate in Sprague-Dawley rats and beagle dogs. Eur. J. Drug Metab. Pharmacokinet. 2017, 42, 453-459. [CrossRef]

339. Shin, B.S.; Hong, S.H.; Bulitta, J.B.; Hwang, S.W.; Kim, H.J.; Lee, J.B.; Yang, S.D.; Kim, J.E.; Yoon, H.S.; Kim, D.J.; et al. Disposition, oral bioavailability, and tissue distribution of zearalenone in rats at various dose levels. J. Toxicol. Environ. Health A 2009, 72, 1406-1411. [CrossRef]

340. Bohn, T.; Desmarchelier, C.; Dragsted, L.O.; Nielsen, C.S.; Stahl, W.; Rühl, R.; Keijer, J.; Borel, P. Host-related factors explaining interindividual variability of carotenoid bioavailability and tissue concentrations in humans. Mol. Nutr. Food Res. 2017, 61, 1600685. [CrossRef] [PubMed]

341. Manach, C.; Scalbert, A.; Morand, C.; Rémésy, C.; Jiménez, L. Polyphenols: Food sources and bioavailability. Am. J. Clin. Nutr. 2004, 79, 727-747. [CrossRef] [PubMed]

342. Dias, D.M.; Costa, N.M.B.; Nutti, M.R.; Tako, E.; Martino, H.S.D. Advantages and limitations of in vitro and in vivo methods of iron and zinc bioavailability evaluation in the assessment of biofortification program effectiveness. Crit. Rev. Food Sci. Nutr. 2018, 58, 2136-2146. [CrossRef] [PubMed]

343. García, Y.; Díaz-Castro, J. Advantages and disadvantages of the animal models v. in vitro studies in iron metabolism: A review. Animal 2013, 7, 1651-1658. [CrossRef] [PubMed]

344. Martinez, M.N.; Rathbone, M.J.; Burgess, D.; Huynh, M. Breakout session summary from AAPS/CRS joint workshop on critical variables in the in vitro and in vivo performance of parenteral sustained release products. J. Control. Release 2010, $142,2-7$. [CrossRef] [PubMed]

345. Gibson, T.M.; Ferrucci, L.M.; Tangrea, J.A.; Schatzkin, A. Epidemiological and clinical studies of nutrition. Semin. Oncol. 2010, 37, 282-296. [CrossRef] [PubMed]

346. Huang, J.; Liu, C.; Wang, Y.; Wang, C.; Xie, M.; Qian, Y.; Fu, L. Application of in vitro and in vivo models in the study of food allergy. Food Sci. Hum. Wellness 2018, 7, 235-243. [CrossRef]

347. Gueven, N.; Spring, K.J.; Holmes, S.; Ahuja, K.; Eri, R.; Park, A.Y.; Fitton, J.H. Micro RNA expression after ingestion of fucoidan; a clinical study. Mar. Drugs 2020, 18, 143. [CrossRef]

348. Ikeda-Ohtsubo, W.; López Nadal, A.; Zaccaria, E.; Iha, M.; Kitazawa, H.; Kleerebezem, M.; Brugman, S. Intestinal microbiota and immune modulation in Zebrafish by fucoidan from Okinawa mozuku (Cladosiphon okamuranus). Front. Nutr. 2020, 7. [CrossRef]

349. Roche-Lima, A.; Carrasquillo-Carrión, K.; Gómez-Moreno, R.; Cruz, J.M.; Velázquez-Morales, D.M.; Rogozin, I.B.; Baerga-Ortiz, A. The presence of genotoxic and/or pro-inflammatory bacterial genes in gut metagenomic databases and their possible link with inflammatory bowel diseases. Front. Genet. 2018, 9. [CrossRef]

350. Nagamine, T.; Nakazato, K.; Tomioka, S.; Iha, M.; Nakajima, K. Intestinal absorption of fucoidan extracted from the brown seaweed, Cladosiphon okamuranus. Mar. Drugs 2015, 13, 48-64. [CrossRef] 
351. Kadena, K.; Tomori, M.; Iha, M.; Nagamine, T. Absorption study of mozuku fucoidan in Japanese volunteers. Mar. Drugs 2018, 16, 254. [CrossRef]

352. Tokita, Y.; Nakajima, K.; Mochida, H.; Iha, M.; Nagamine, T. Development of a fucoidan-specific antibody and measurement of fucoidan in serum and urine by sandwich ELISA. Biosci. Biotechnol. Biochem. 2010, 74, 350. [CrossRef] [PubMed]

353. Mathieu, S.; Touvrey-Loiodice, M.; Poulet, L.; Drouillard, S.; Vincentelli, R.; Henrissat, B.; Skjåk-Bræk, G.; Helbert, W. Ancient acquisition of "alginate utilization loci" by human gut microbiota. Sci. Rep. 2018, 8, 8075. [CrossRef]

354. Song, T.; Xu, H.; Wei, C.; Jiang, T.; Qin, S.; Zhang, W.; Cao, Y.; Hu, C.; Zhang, F.; Qiao, D.; et al. Horizontal transfer of a novel soil agarase gene from marine bacteria to soil bacteria via human microbiota. Sci. Rep. 2016, 6, 34103. [CrossRef] [PubMed]

355. Pudlo, N.A.; Pereira, G.V.; Parnami, J.; Cid, M.; Markert, S.; Tingley, J.P.; Unfried, F.; Ali, A.; Campbell, A.; Urs, K.; et al. Extensive transfer of genes for edible seaweed digestion from marine to human gut bacteria. bioRxiv 2020, 2020.06.10.142968. [CrossRef]

356. Hehemann, J.-H.; Correc, G.; Barbeyron, T.; Helbert, W.; Czjzek, M.; Michel, G. Transfer of carbohydrate-active enzymes from marine bacteria to Japanese gut microbiota. Nature 2010, 464, 908-912. [CrossRef]

357. Thomas, F.; Barbeyron, T.; Tonon, T.; Génicot, S.; Czjzek, M.; Michel, G. Characterization of the first alginolytic operons in a marine bacterium: From their emergence in marine Flavobacteriia to their independent transfers to marine Proteobacteria and human gut Bacteroides. Environ. Microbiol. 2012, 14, 2379-2394. [CrossRef]

358. Baldrick, F.R.; McFadden, K.; Ibars, M.; Sung, C.; Moffatt, T.; Megarry, K.; Thomas, K.; Mitchell, P.; Wallace, J.M.; Pourshahidi, L.K.; et al. Impact of a (poly) phenol-rich extract from the brown algae Ascophyllum nodosum on DNA damage and antioxidant activity in an overweight or obese population: A randomized controlled trial. Am. J. Clin. Nutr. 2018, 108, 688-700. [CrossRef] [PubMed]

359. D'Archivio, M.; Filesi, C.; Varì, R.; Scazzocchio, B.; Masella, R. Bioavailability of the polyphenols: Status and controversies. Int. J. Mol. Sci. 2010, 11, 1321-1342. [CrossRef] [PubMed]

360. Sęczyk, Ł.; Świeca, M.; Kapusta, I.; Gawlik-Dziki, U. Protein-phenolic interactions as a factor affecting the physicochemical properties of white bean proteins. Molecules 2019, 24, 408. [CrossRef] [PubMed]

361. Buitimea-Cantúa, N.E.; Gutiérrez-Uribe, J.A.; Serna-Saldívar, S.O. Phenolic-protein interactions: Effects on food properties and health benefits. J. Med. Food 2018, 21, 188-198. [CrossRef] [PubMed]

362. Zhang, Q.; Cheng, Z.; Wang, Y.; Fu, L. Dietary protein-phenolic interactions: Characterization, biochemical-physiological consequences, and potential food applications. Crit. Rev. Food Sci. Nutr. 2020, 1-27. [CrossRef]

363. Imbs, T.; Zvyagintseva, T. Phlorotannins are polyphenolic metabolites of brown algae. Russ. J. Mar. Biol. 2018, 44, 263-273. [CrossRef]

364. Zhang, H.; Yu, D.; Sun, J.; Liu, X.; Jiang, L.; Guo, H.; Ren, F. Interaction of plant phenols with food macronutrients: Characterisation and nutritional-physiological consequences. Nutr. Res. Rev. 2013, 27, 1-15. [CrossRef]

365. Mignet, N.; Seguin, J.; Chabot, G.G. Bioavailability of polyphenol liposomes: A challenge ahead. Pharmaceutics 2013, 5, 457-471. [CrossRef]

366. Jakobek, L.; Matić, P. Non-covalent dietary fiber-polyphenol interactions and their influence on polyphenol bioaccessibility. Trends Food Sci. Technol. 2019, 83, 235-247. [CrossRef]

367. Bohn, T. Dietary factors affecting polyphenol bioavailability. Nutr. Rev. 2014, 72, 429-452. [CrossRef]

368. Wojtunik-Kulesza, K.; Oniszczuk, A.; Oniszczuk, T.; Combrzyński, M.; Nowakowska, D.; Matwijczuk, A. Influence of in vitro digestion on composition, bioaccessibility and antioxidant activity of food polyphenols-a non-systematic review. Nutrients 2020, 12, 1401. [CrossRef]

369. Sookkasem, A.; Chatpun, S.; Yuenyongsawad, S.; Wiwattanapatapee, R. Alginate beads for colon specific delivery of selfemulsifying curcumin. J. Drug Deliv. Sci. Technol. 2015, 29, 159-166. [CrossRef]

370. Hussain, M.B.; Hassan, S.; Waheed, M.; Javed, A.; Farooq, M.A.; Tahir, A. Chapter 5-Bioavailability and metabolic pathway of phenolic compounds. In Plant Physiological Aspects of Phenolic Compounds; Soto-Hernández, M., Palma-Tenango, M., García-Mateos, R., Eds.; IntechOpen: Rijeka, Croatia, 2019. [CrossRef]

371. Luca, S.V.; Macovei, I.; Bujor, A.; Miron, A.; Skalicka-Woźniak, K.; Aprotosoaie, A.C.; Trifan, A. Bioactivity of dietary polyphenols: The role of metabolites. Crit. Rev. Food Sci. Nutr. 2020, 60, 626-659. [CrossRef] [PubMed]

372. Carregosa, D.; Carecho, R.; Figueira, I.; Santos, C.N. Low-molecular weight metabolites from polyphenols as effectors for attenuating neuroinflammation. J. Agric. Food Chem. 2020, 68, 1790-1807. [CrossRef] [PubMed]

373. Liu, Z.; Hu, M. Natural polyphenol disposition via coupled metabolic pathways. Expert Opin. Drug Metab. Toxicol. 2007, 3, 389-406. [CrossRef]

374. Suetsuna, K.; Maekawa, K.; Chen, J.-R. Antihypertensive effects of Undaria pinnatifida (wakame) peptide on blood pressure in spontaneously hypertensive rats. J. Nutr. Biochem. 2004, 15, 267-272. [CrossRef] [PubMed] 
375. Pimenta, D.C.; Lebrun, I. Cryptides: Buried secrets in proteins. Peptides 2007, 28, 2403-2410. [CrossRef]

376. Hayes, M.; García-García, M.; Fitzgerald, C.; Lafarga, T. Chapter 27-Seaweed and milk derived bioactive peptides and small molecules in functional foods and cosmeceuticals. In Biotechnology of Bioactive Compounds: Sources and Applications; Gupta, V.K., Tuohy, M.G., Eds.; John Wiley \& Sons: Oxford, UK, 2015; pp. 669-691. [CrossRef] 